UNIVERSIDADE DE BRASÍLIA

FACULDADE DE CIÊNCIAS DA SAÚDE

PÓS-GRADUAÇÃO EM PATOLOGIA MOLECULAR

EXPRESSÃO DE PROTEÍNA PARASPORINA 2 (PS2) DE BACILLUS THURINGIENSIS EM CÉLULAS DE INSETO E ANÁLISE DE SUA TOXICIDADE PARA CÉLULAS TUMORAIS E DE INSETOS

Deborah da Costa Lamar

Orientador: Dr. Bergmann Morais Ribeiro

Brasília

Julho/2016 


\section{EXPRESSÃO DA PROTEÍNA PARASPORINA 2 (PS2) DE BACILLUS THURINGIENSIS EM CÉLULAS DE INSETO E ANÁLISE DE SUA TOXICIDADE PARA CÉLULAS TUMORAIS E DE INSETOS}

Dissertação apresentada ao Programa de Pós-Graduação em Patologia Molecular da Faculdade de Saúde, da Universidade de Brasília, como parte dos requisitos necessários para obtenção do título de Mestre em Patologia Molecular.

Orientador: Prof. Dr. Bergmann Morais Ribeiro

BRASÍLIA

JULHO/2016 


\title{
EXPRESSÃO DE PROTEÍNA PARASPORINA 2 (PS2) DE BACILLUS THURINGIENSIS EM CÉLULAS DE INSETO E ANÁLISE DE SUA TOXICIDADE PARA CÉLULAS TUMORAIS E DE INSETOS
}

\begin{abstract}
Dissertação apresentada ao Programa de Pós-Graduação em Patologia Molecular da Faculdade de Saúde, da Universidade de Brasília, como parte dos requisitos necessários para obtenção do título de Mestre em Patologia Molecular.
\end{abstract}

Aprovada em

BANCA EXAMINADORA

Prof. Dr. Bergmann Morais Ribeiro (Presidente)

Dra. Érica Soares Martins Queiroz (Membro Titular)

Prof. Dr Osmindo Rodrigues Pires Júnior (Membro Titular)

Prof. Dr. José Raimundo Corrêa (Membro Suplente) 
"Confia ao SENHHOR as tuas obras e os

teus desígnios serão estabelecidos" Pv 16:3 
À minha querida Avó Yedda Lamar (in memorian) por tudo o que ela foi e sempre será para mim. Por todo apoio, incentivo e torcida pela realização desse sonho. Dedico. 


\section{AGRADECIMENTOS}

Agradeço primeiramene a Deus, quem me deu vida, sabedoria, inteligência, força e esperança! Obrigada, por em todo tempo estar comigo e me lembrar de todos os dias quem eu sou.

Agradeço a toda minha família que sempre me apoiou, principalmente a minha Tia Emília (Tia Mimi) que desde sempre foi um grande exemplo de perceverança e responsabilidade. Uma pessoa muito querida por mim, que me criou, ensinando-me a ser uma pessoa de bom caráter e responsável. Obrigada por tudo que você já fez e faz por mim! Agradeço a minha mãe, por ter me gerado com tanto amor e por continuar sendo uma mãe tão amorosa e dedicada. Obrigada por todas as palavras de incentivo durante essa caminhada! Aos meus irmãos que são grandes exemplos. Meu irmão, Lucas, obrigada por ser quem você é, por me ensinar a ser uma pessoa forte, uma pessoa que vence seus próprios desafios, mesmo que sejam muito difíceis. Rachel, minha irmã, obrigada por através do seu amor pelo ballet, me mostrar e ensinar o quanto é importante fazer aquilo que amamos! Essa conquista é nossa, família. Obrigada por acreditarem em mim, amo vocês!

Agradeço ao professor Bergmann, que me aceitou em seu laboratório e me ensinou muito com seu amor e dedicação ao que faz. Obrigada por toda paciência e confiaça depositada a mim.

Agradeço a todo o grupo Baculovírus, mas em especial, Lorena, obrigada por tudo o que você me ensinou, por todo o tempo e paciência em me ajudar. Obrigada pelos momentos vividos e pela amizade! Mayarha e Laís, obrigada pela companhia e amizade! Daniel, Fabrício e Miguel, muito obrigada por tudo que vocês me ensinaram ao longo desses anos e por toda ajuda dedicada a mim. Fernando sou muito grata a você, afinal você foi parte principal da formação de quem sou hoje. Mari, longe hoje, mas perto de coração. Muito obrigada pela pessoa que você é, foram muito bons os momentos que passamos juntas, de muito aprendizado e experiência. Sua vida me inspira!

Agradeço a todo o grupo da Virologia vegetal (laboratório professor Renato e professor Tatsuya), por toda ajuda ao longo desses anos e companheirismo. Karina e Raquel, obrigada pelos momentos, almoços, conversas! 
Agradeço a todo o grupo do laboratório de Microscopia Eletrônica e Cultura de célula de mamífero, por toda ajuda. Márcia e Yasmin, eu não tenho palavras para agradecer vocês, muito obrigada por tudo. Essa conquista também é de vocês!

Agradeço a professora Tatiana Karla e ao professor Paulo Queiroz por terem sido exemplos de profissionalismo e incentivo na pesquisa, e principalmente ao Paulo por ter me apresentado esse mundo.

Aos amigos, de graduação (Camilla, Danilo, Fernanda, Letícia, Mayara e Ranna); as amigas (Adlla, Carol, Geisy, Jéssica, Maressa e Sthael); e a família que construí (Ana Beatriz, Bela, Bel, Bruno, Carol, Carol França, Carol Vogado, Day, Deborah Cordeiro, Déborah Santos, Fernanda, Fernandinha, Gabriel Tótoli, Gil, Giordano, Gui Coêlho, Gui Costa, Gustavo, Igor, Isa, Larissa Costa, Larissa, Lígia, Luíza, Marina, Mary, Mateus, Nathália Barbachan, Rabetti, Rayane, Stefane, Tauana e Victor). Obrigada por tudo, vocês me inspiram a cada dia!!

Vanessa Laís e Nathalia Moreira, minhas amigas, desde o começo torcendo por mim, muito obrigada pela caminhada, pelos ensinamentos, palavras de encorajamento, pela torcida. Vocês são partes principais dessa conquista!

João Marcos (Coach João), obrigada por tudo o que você me ensinou. Obrigada pelo passo dado na descoberta do meu sonho e pelo incentivo. Obrigada por me ensinar o caminho da esperança e da coragem!

Agradeço ao CNPq pela bolsa durante esses dois anos e a Universidade de Brasília por toda a estrutura. 


\section{ÍNDICE GERAL}

AGRADECIMENTOS ..........................................................................................................

ÍNDICE GERAL................................................................................................................... vii

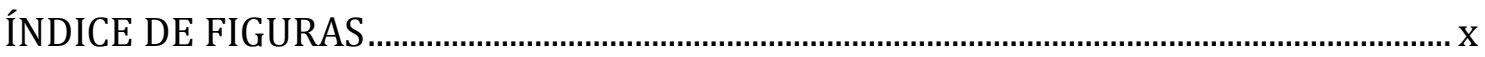

LISTA DE ABREVIATURAS E SÍMBOLOS .............................................................................. xiii

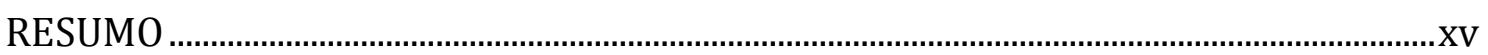

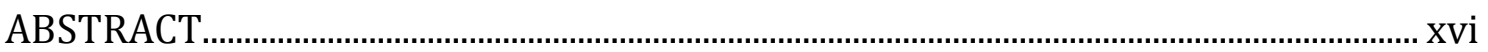

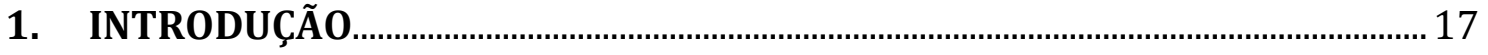

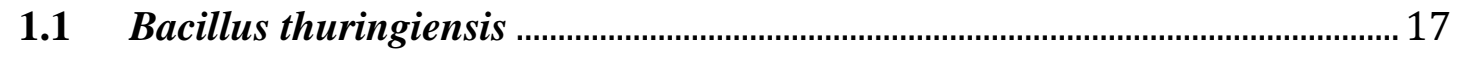

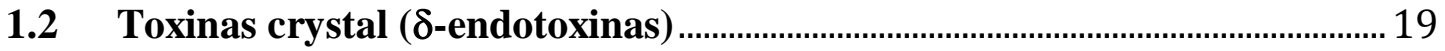

1.3 Estrutura tridimensional das proteínas Cry ................................................................ 25

1.4 Modo de ação das proteínas Cry .............................................................................. 25

1.4.1 Modo de ação por formação de poros ................................................................ 26

1.4.2 Modo de ação por transdução de sinal ............................................................... 30

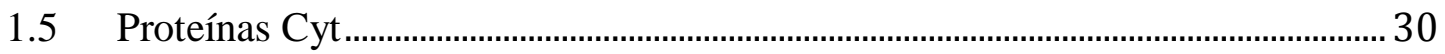

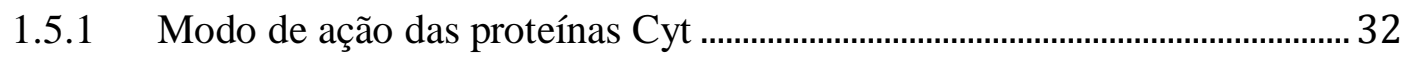

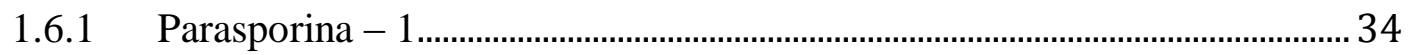

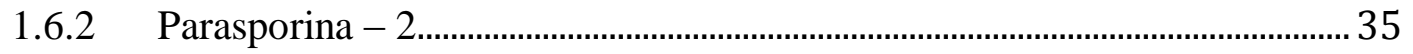

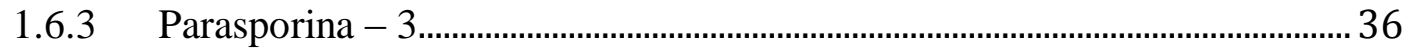

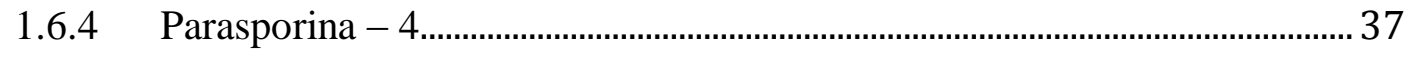

1.6.5 Estrutura tridimensional das Parasporinas 2 e 4................................................ 38

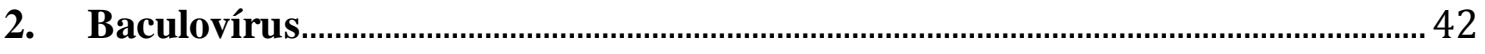

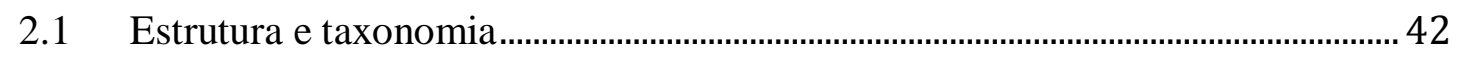

2.2 Baculovírus como vetor de expressão ................................................................... 43

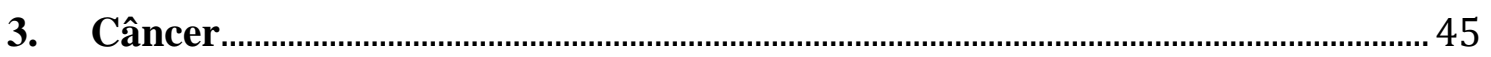

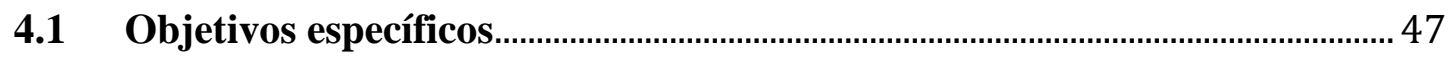

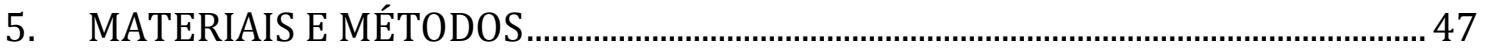

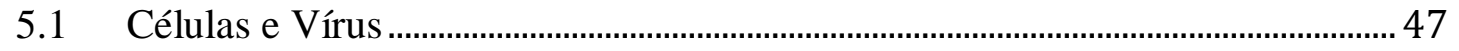

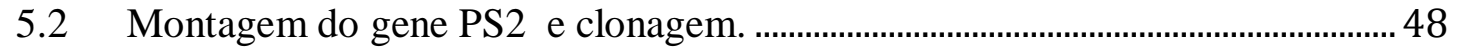

5.4 Obtenção do baculovírus recombinante .................................................................. 53

5.4.1 Transfecção em células de inseto e amplificação do vírus. ........................... 55

5.5 Análise da expressão da proteína recombinante....................................................... 57

5.6 Cinética de expressão e visualização de cristais em célula de inseto....................58

5.7 Caracterização morfológica de cristais de PS2 por microscopia eletrônica de varredura (MEV). 
5.8 Purificação, solubilização, ativação e quantificação da toxina parasporina - 2 . 59

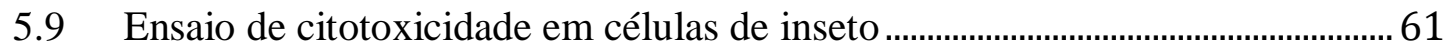

5.10 Ensaio de viabilidade celular em célula tumoral de mamífero ........................... 63

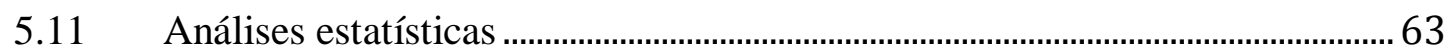

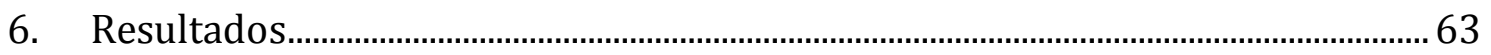

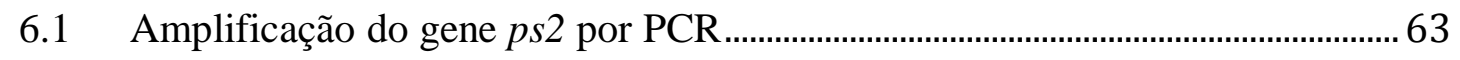

6.4 Construção do baculovírus recombinante contendo o gene $p s 2$............................ 67

6.6 Cinética de expressão da proteína recombinante e visualização de cristais em

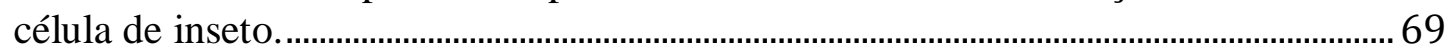

6.7 Purificação, solubilização e ativação da toxina PS2 .............................................. 72

6.8 Caracterização ultraestrutural dos possíveis cristais da proteína PS2 ............... 73

6.10 Ensaio de viabilidade em células de inseto................................................................ 77

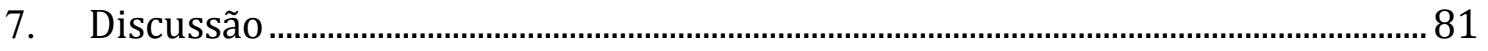

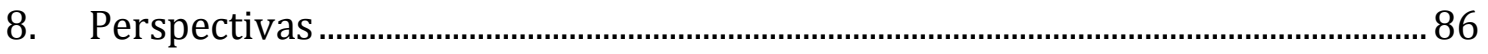

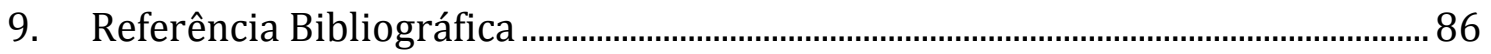




\section{ÍNDICE DE FIGURAS}

Figura 1. Alinhamento das estruturas primárias das toxinas Cry de Bacillus

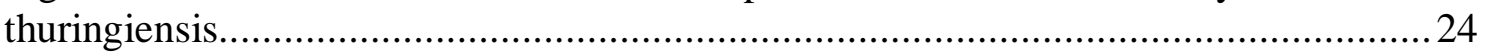

Figura 2. Representação da estrutura de tês domínios de proteínas Cry.......................2 24

Figura 3. Representação esquemática dos sítios de clivagem por proteases em algumas

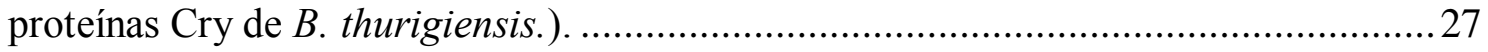

Figura 4 Receptores moleculares da proteína Cry1Aa. CADR, receptor do tipo caderina; APN, receptor aminopeptidase-N; ALP, receptor fosfatase alcalina; GCR, receptor glicoconjugado de $270 \mathrm{kDa}$ (Bravo et al., 2007) .....................................................28

Figura 5. Modo de ação de proteinnas Cry1A por formação de poros na membrana.. .. 29

Figura 6. Representação estrutural de proteína Cyt................................................... 31

Figura 7. Representação dos dois possíveis modelos de ação de proteínas Cyt............. 32

Figura 8.Comparação estrutural entre parasporina - 2, proteína não tóxica de $26 \mathrm{kDa}$ e

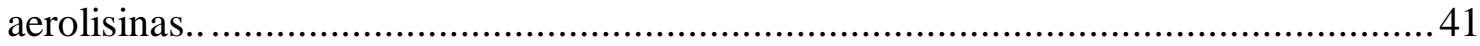

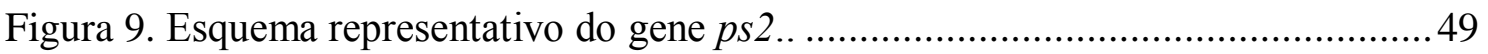

Figura 10. Esquema representativo da construção do gene $p s 2$ por overlap...................50

Figura 11. Esquema do vetor pGem - T Easy (Promega)........................................51

Figura 12. Esquema do vetor pFastBac1 (Invitrogen) ...........................................52

Figura 13. Esquema ilustrativo da construção de baculovírus recombinantes pelo método de transposição sítio-dirigida (adaptado do manual Bac-to-Bac® Baculovirus

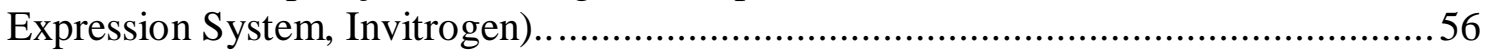

Figura 14. Confirmação da amplificação do gene $p s 2$ por PCR. . .................................. 64

Figura 15. Mapa representativo do plasmídeo pGemPs26xHis.. ................................65

Figura 16. Confirmação da clonagem do gene ps2 no plasmídeo pGem- Teasy.).........65

Figura 17. Mapa representativo do plasmídeo pFastBacPs26xHis...............................66

Figura 18. Confirmação da clonagem do gene ps2 no plasmídeo pFastBac1. .............67

Figura 19. Confirmação da construção do vírus recombinante (Bacmídeo) por PCR

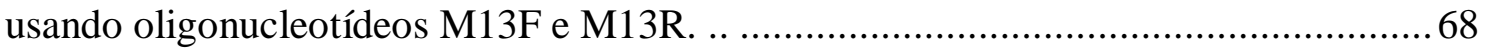

Figura 20. Confirmação da expressão de PS2 em células de inseto..............................69

Figura 21. Cinética de formação de cristais por SDS - PAGE e Western blot................ 70

Figura 22. Análise morfológica de células infectadas pelo vírus recombinante por

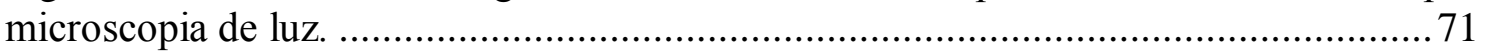

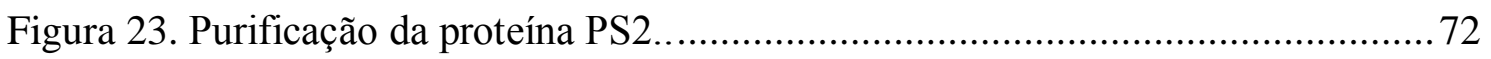

Figura 24. Solubilização e ativação da protoxina PS2. SDS-PAGE a 12\% mostrando a presença da proteína PS2 após solubilização e ativação por proteinase K.. ..................73

Figura 25. Caracterização ultraestrutural de possíveis cristais de PS2 ........................ 74

Figura 26. Análise da viabilidade celular em células infectadas pelos vírus

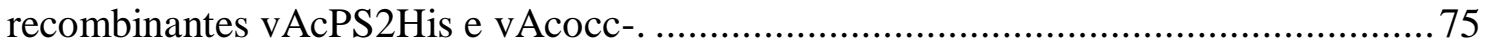


Figura 27. Análise morfológica de células de inseto infectadas pelos vírus reombinantes

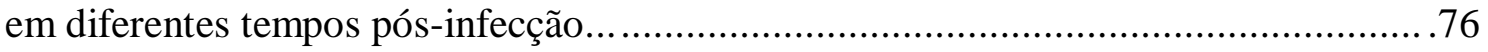

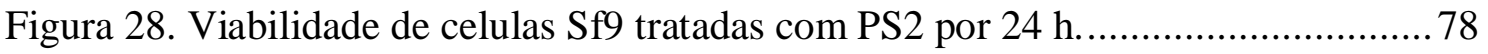

Figura 29. Análise estrutural de células Sf9 tratadas com a proteína recombinantes PS2..

Figura 30. Análise da viabilidade de células tumorais e não tumorais tratadas com

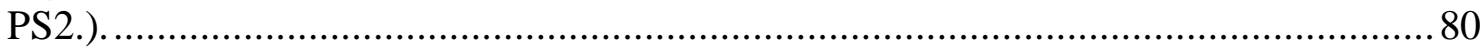

Figura 31. Micrografia de luz de células tumorais e não tumorais humanas tratadas com PS2 em 24h. 81 


\section{ÍNDICE DE TABELAS}

Tabela 1. Resumo mostrando o espectro de especificidade de toxinas cry para cada hospedeiro.

Tabela 2 Estimativas de novos casos de câncer em Homens e Mulheres em 2016/2017 (INCA 2016). 


\section{LISTA DE ABREVIATURAS E SÍMBOLOS}

$\begin{array}{ll}\text { Amp } & \text { ampicilina } \\ \text { BSA } & \text { albumina sérica bovina } \\ B t & \text { Bacillus thuriniensis } \\ \text { Bti } & \text { Bacillus thuringiensis subespécie israelensis } \\ \text { EDTA } & \text { Ácido etilenodiaminotetraacético } \\ \text { dNTP } & \text { desoxinucleotídeos } \\ \text { Gentam } & \text { gentamicina } \\ \text { h.p.i } & \text { horas pós }- \text { infecção } \\ \text { kb } & \text { quilobase }=1000 \text { pares de base } \\ \text { kDa } & \text { quilodalton } \\ \text { ul } & \text { microlitro } \\ \text { M } & \text { molar } \\ \text { mg } & \text { miligrama } \\ \text { ug } & \text { micrograma }-10^{-6} \text { grama } \\ \text { mL } & \text { mililitro } \\ \text { mM } & \text { milimolar } \\ \text { MOI } & \text { multiplicidade de infeção } \\ \text { ng } & \text { nanograma }=10^{-9} \text { grama } \\ \text { pb } & \text { pares de base } \\ \text { PCR } & \text { reação em cadeia da polimerase } \\ \text { pH } & \text { potencial de hidrogênio } \\ \text { pfu } & \text { unidade formadora de placa } \\ \text { PMSF } & \text { fenilmetanosulfonilfluoreto } \\ \text { SDS } & \text { eletroforese em gel de poliacrilamida desnaturante em } \\ \text { SDS-PAGE } & \\ & \text { SDS } \\ & \end{array}$


Tn7L e Tn7R elementos de transposição sítio específica do transposon bacteriano $\operatorname{Tn} 7$

Tris

$\mathrm{U}$

vAcPS2his
$\mathrm{N}, \mathrm{N}, \mathrm{N}^{`}, \mathrm{~N}^{`}$ - tetrametil etilenodiamina

unidade enzimática

baculovírus recombinante com gene parasporina -2 com cauda de histidina 


\section{RESUMO}

Bacillus thuringiensis é uma bactéria Gram positiva, produtora de cristais protéicos ou $\delta$-endotoxinas (toxinas Cry e Cyt) durante a fase de esporulação. As toxinas. Cry apresentam atividade inseticida específica, e as toxinas Cyt apresentam atividade citolítica inespecífica. Algumas proteínas produzidas por B. thuringiensis durante a fase de esporulação que não apresentam caráter inseticida, mas apresentam-se tóxica para células tumorais foram descritas. Essas proteínas receberam o nome de Parasporinas (PS), devido à capacidade de produzir cristais paraesporais e até o momento são classificadas em seis tipos (PS1-PS6). Baculovírus são vírus de insetos usados no controle biológico de pragas da agricultura, porém também têm sido muito utilizados como vetores de expressão de proteínas heterólogas em células de inseto. No presente trabalho, o gene ps 2 foi montado, por meio de PCR, através de fragmentos sintetizados a partir de uma sequência lotada no banco de dados, e o produto de PCR foi clonado em um vetor de transferência para construção de um baculovírus recombinante. Após obtenção do vírus recombinante, observou-se que células SF9 quando infectadas com vAcPS2, morriam em um tempo curto de infecção, quando comparado com células infectadas com o vírus selvagem. Após purificação, solubilização e ativação da toxina PS2 recombinante, ensaios de viabilidade celular foram feitos com linhagens de células tumorais, câncer mamário (MCF-7) e câncer mamário metastático (MDA-MB-231), células não tumorais humanas (fibroblastos) e células de inseto (Sf9), confirmando a atividade tóxica de PS2 apenas para as células tumorais. 


\section{ABSTRACT}

Bacillus thunringiensis is a Gram positive bacterium that produces crystal forming proteins called $\delta$-endotoxins (Cry and Cyt toxins), during sporulation phase. Cry toxins show specific insecticidal activity, and Cyt toxins shows non-specific cytolitic activity. Some proteins of $B$. thuringiensis produced during sporulation have not shown insecticidal activity, but a specific toxic activity to some cancer cells. These proteins were called Parasporins (PS) due to their ability to form paraporal crystals and they are divided in six groups (PS1-PS6). Baculoviruses are insect viruses that have been widely used as biological control of agricultural pests, but also as expression vectors of heterologous proteins in insect cells. In this work, the gene ps2, constructed by PCR, trough fragments synthetized using a gene sequence from a database and cloned in a transfer vector for recombinant virus construction After recombinant virus construction we observed that SF9 cells died faster than cells infected with the wild-type virus. After purification, solubilization and activation of the heterologous protein, cell viability assays was performed with cancer cell lines, breast cancer (MCF-7), metastatic brest cancer (MDA-MB-231), non-tumor human cells (fibroblasts) and insect cells (Sf9) confirming PS2 toxic activity only to cancer cells. 


\section{INTRODUÇÃ̃O}

\subsection{Bacillus thuringiensis}

Em meados de 1901, o cientista japonês Shigetane Ishiwata, isolou uma bactéria das larvas doentes do bicho da seda, Bombix mori, (Aizawa \& Ishiwata, 1901) enquanto investigava a causa da doença súbita, conhecida como "sotto disease", doença responsável pela morte de muitos bichos da seda no Japão. Tal descoberta fez com que Ishiwata nomeasse a bactéria como Bacillus sotto (Aoki \& Chegãzaki, 1915). Em 1911 o cientista alemão, Ernst Berliner, isolou a mesma bactéria, mas dessa vez de larvas da traça da farinha. Esta foi nomeada como Bacillus thuringiensis devido à cidade alemã, Thuringia, onde foi isolada.

B. thuringiensis pertence à família Bacillaceae, a qual engloba a maioria das espécies formadoras de esporos, sendo estes localizados na região central ou paracentral, quando no interior da célula-mãe. É também uma bactéria em forma de bastão, Gram positiva, com célula vegetativa de 1,0 a 1,2 $\mu$ m de largura por 3,0 a 5,0 $\mu \mathrm{m}$ de comprimento, sendo aeróbia não estrita com faixa de temperatura de crescimento entre 10 e $45^{\circ} \mathrm{C}$. (Glare \& O’Callaghan, 2000; Habib \& Andrade, 1998; Vilas-Bôas, et al., 2007). É isolada a partir de uma variedade de ecossistemas, como, solo, água, insetos mortos, superfície de plantas, teias de aranha, grãos armazenados e até tecidos humanos em decomposição (Hofte \& Whiteley, 1989; Knowles \& Dow, 1993; Bravo et al., 1998; Roh et al., 2007; Raymond et al., 2010).

B. thuringiensis apresenta em seu ciclo de vida uma fase de esporulação onde são produzidos cristais proteicos ou inclusões cristalinas, sendo esta uma característica marcante para a espécie, distinguindo-a das demais espécies pertencentes ao grupo Bacillus cereus, ao qual também faz parte (Didelot et al., 2009). Estes cristais são formados por proteínas chamadas de $\delta$-endotoxinas e apresentam atividade entomopatogênica para várias espécies de insetos, destacando-se as ordens de 
lepidopteros, dipteros e coleopteros. Porém, foi descoberto que, subespécies de $B$. thuringiensis tem apresentado toxicidade contra insetos das ordens Himenoptera, Hemiptera, Orthoptera, Phthraphera e também para alguns nematóides, protozoários e ácaros (Glare \& O’Callaghan, 2000)

A produção de cristais de $\delta$-endotoxinas, além de ser uma característica marcante para a espécie, fez com que B. thuringiensis ganhasse importância mundial como alternativa no uso de inseticidas, pois as $\delta$-endotoxinas são altamente específicas para seu inseto alvo, sendo inofensivas para os seres humanos, animais vertebrados e plantas, e completamente biodegradáveis (Bravo et al., 2005), por esse motivo, $B$. thuringiensis é uma valiosa fonte de proteínas com função inseticida que são alternativas aos pesticidas químicos, para o controle de importantes pragas agrícolas, como por exemplo, Spodoptera frugiperda e Anticarsia gemmatalis, e de população de pragas vetores de doenças humanas e de animais, que incluem os mosquitos vetores da malária, doenças virais (febre amarela, dengue, chikungunya e zika) e filariose linfática (Becker, 2000).

No início da fase de esporulação e durante a fase estacionária, B. thuringiensis produz dois tipos de toxinas paraesporais que são classificadas como $\delta$-endotoxinas e essas são de dois tipos, as proteínas cristal (ou toxinas Cry) codificadas pelos gene cry e proteínas citolíticas (ou toxinas Cyt) codificadas pelos genes cyt. (Glare \& O’Callaghan, 2000; Habib \& Andrade, 1998; Arantes et al., 2007). Proteínas Cry são especialmente tóxicas para ordens de insetos Lepidoptera, Coleoptera, Himenoptera e Diptera e também para nematoides. (Bravo et al., 2005). É descrita como proteína de inclusão paraesporal (Crystal) de B. thuringiensis que exibe efeitos tóxicos para um organismo alvo, ou alguma proteína que apresenta identidade com uma proteína Cry conhecida. Em contra partida, as proteínas Cyt são tóxicas para insetos da ordem Diptera in vivo (Crickmore et al., 1998), mas exibem citotoxicidade para células de dipteros e de 
mamíferos in vitro (Koni, et al., 1994). Proteínas Cyt são descritas como proteínas de inclusão paraesporal de $B$. thuringiensis, mas que apresentam atividade (citolítica) hemolítica ou possuem identidade com proteínas Cyt conhecidas. (Crickmore et al., 1998).

Além das proteínas Cry e Cyt, outras proteínas são sintetizadas como cristais paraesporais por estirpes de $B$. thuringiensis durante a fase de esporulação, porém, até o momento, estas não apresentam nenhuma atividade tóxica para insetos testados, mas sim uma forte e específica atividade citotóxica contra células tumorais. Estas foram denominadas como parasporinas, recebendo como nome alternativo parasporina -1 (PS1), parasporina - 2 (PS2), parasporina - 3 (PS3), parasporina - 4 (PS4), parasporina - 5 (PS5) e parasporina - 6 (PS6). Há também, outra classe de proteínas tóxicas sintetizadas por $B$. thuringiensis, sendo estas produzidas durante a fase vegetativa de crescimento, onde são secretadas dentro do meio de cultura. Estas foram denominadas como proteínas inseticidas da fase vegetativa (do inglês, vegetative insecticidal proteins ou protéinas Vip). Proteínas vip são classificadas em quatro famílias Vip1, vip2, Vip3 e Vip4, de acordo com o grau de identidade entre aminoácidos (Warren et al., 1998).

\section{$1.2 \quad$ Toxinas Crystal ( $\delta$-endotoxinas)}

B. thuringiensis, durante sua fase estacionária, produz corpos de inclusões proteicos que são compostos por $\delta$-endotoxinas, que durante essa fase de desenvolvimento acumulam-se no compartimento da célula-mãe, e quando chega ao final do estágio de esporulação, são liberados juntamente com o esporo (Schnepf et al., 1998). As $\delta$ endotoxinas são compostas por dois tipos de proteínas, Cry e Cyt, onde a maioria das estirpes de B. thuringiensies são capazes de sintetizar mais de um tipo de cristal. Os cristais quando formados podem ser constituídos por diferentes proteínas Cry e/ou Cyt, podendo haver casos em que são encontradas cinco toxinas ao mesmo tempo, como por 
exemplo o B. thuringiensis subsp. israelensis. O cristal formado pode-se apresentar de formas diferentes e essa forma é determinada devido a composição e estrutura das $\delta$ endotoxinas presentes, podendo este ser bipiramidal, cuboide, romboide, ovóide, esférico ou sem forma definida (Habib \& Andrade, 1998).

As toxinas Cry e Cyt pertencem a uma classe denominada de toxinas formadoras de poros (pore-forming toxins - PFT's), sendo esta uma das principais classes de toxinas que causam danos à membrana alvo. Estas quando entram em contato com a membrana celular sofrem modificações na sua estrutura, o que ocasiona a formação de poros na membrana, levando a célula à morte. PFT's são classificadas em dois grupos, sendo o primeiro $\alpha$ - toxinas formadoras de poros ( $\alpha$-pore-forming toxins $-\alpha$-PFT's) que engloba toxinas como colicinas, exotoxina A, toxina da difteria e toxinas Cry de três domínios (Cry three-domain). Essas toxinas apresentam uma estrutura de três domínios onde um desses domínios é o responsável pela inserção na membrana e formação de poros. O segundo grupo corresponde a $\beta$ - toxinas formadoras de poros ( $\beta$ pore-forming toxins - $\beta$-PFT's) que também são inseridas na membrana na forma de um barril- $\beta$. Esta classe engloba aerolisinas, $\alpha$-hemolisina, anthrax protective antigen, toxinas dependentes de cholesterol, como perfringolysin $O$, e toxinas Cyt. A maioria dessas toxinas tem como característica a interação específica com receptores localizados na superfície celular do hospedeiro (Geny et al., 2006; Gonzales et al., 2008; Feil et al., 2010)

Ao final dos anos 80, Hofte e Whitely (1989) proproram um tipo de classificação para as toxinas de B. thuringiensis, baseada na sequência de aminoácidos e no espectro inseticida. Na época foram relatadas 42 sequências de genes que codificavam para proteínas Crystal (Cry), sendo que estas apresentavam similaridade de sequência de aminoácidos. Estes genes foram então divididos em um número mínimo de classes, onde cada classe foi caracterizada de acordo com o espectro inseticida, além 
da similaridade de sequência de aminoácidos, e um número romano foi adicionado ao nome, indicando a qual classe esta toxina representa (ex. CryI), ou seja: Classe I (CryI) - proteína que apresenta atividade inseticida específica para insetos da ordem Lepidóptera; Classe II (CryII) - Lepidópteros e Dípteros; Classe III (CryIII) Coleópteros e; Classe IV (CryIV) - Dípteros. Outras classes foram criadas depois, onde proteínas que não apresentavam atividade inseticida foram adicionadas, ou até mesmo a proteína Cyt, que é uma toxina formadora de cristal mas que não apresenta homologia com as demais proteínas Cry. Passados alguns anos, já ao final dos aos 90, o Comitê de Nomenclatura de toxinas de B. thuringiensis foi criado com o intuito de evitar problemas para classificar novas toxinas, visto que era necessário fazer bioensaios para uma lista de insetos para saber se a toxina testada possuía alguma atividade inseticida (Crickmore et al., 1998). Esse novo sistema faz com que as toxinas sejam classificadas de acordo com a sua homologia na sequência de aminoácidos, onde a denominação Cry apresenta quatro categorias hierárquicas que são representadas por números e letras (maiúsculas e minúsculas), como por exemplo Cry4aC. Proteínas que apresentam $45 \%$ de identidade em sua sequência são colocadas no primeiro nível, quando apresentam 78\%, fazem parte do segundo nível e, quando apresentam 95\%, o terceiro nível. O quarto e último nível é indicado por um número que representa identidade de sequência de aminoácidos maior que 95\% (ex. Cry4Aa1) (De maagd et al., 2001). O mesmo é aplicado para outras toxinas de $B$. thuringiensis, como Cyt, também $\delta$-endotoxinas e para toxinas secretadas (Vip).

Até o dado momento, as toxinas Cry tem formado um grande grupo de proteínas inseticidas, onde o Comitê de Nomenclatura de toxinas de Bt (Bacillus thuringiensis Toxin Nomenclature Avaiable online: http://www.lifesci.sussex.ac.uk/Home/Neil_Crickmore/Bt/) classificou 74 tipos diferentes de proteínas Cry (Cry 1 a Cry73), que inclui proteínas da família de três 
domínios, de Bacillus thuringiensis, e toxina binária "binary Bin -“e ETX_MTX2- like de Bacillus sphaericus, que não são proteínas de três domínios, mas que também fazem parte deste grande grupo (Palma et al., 2015).

Ao longo dos anos vários estudos mostraram que toxinas Cry apresentaram uma vasta toxicidade, devido a receptores específicos para ligação da toxina na membrana do inseto hospedeiro, sendo estes insetos de diferentes ordens, como Lepidoptera (borboletas e mariposas), Diptera (mosquitos e borrachudos), Coleoptera (besouros), Hemiptera, Nematoda (parasitas humanos e animais) (Höfte et al., 1989; Schneph et al., 1998; Van Frankenhuyzen et al., 2009; Ben-Dov, 2014; De maagd et al., 2003; Chougule et al., 2012; Bravo et al., 2008), e também em várias linhagens de células de câncer humano (Ohba et al., 2016; Parasporin Nomenclature. Avaiable on line) (Tabela 1).

Tabela 1. Resumo mostrando o espectro de especificidade de toxinas cry para cada hospedeiro (Adaptado de Palma et al., 2015)

\begin{tabular}{|l|l|} 
& $\begin{array}{r}\text { Toxinas Crystal de Bacillus thuringiensis ( } \delta- \\
\text { endotoxinas) }\end{array}$ \\
\hline Lepidópteras & Cry1A-K; Cry2ACr7B; Cry8D; Cry9A-C,E; Cry15A Cry22a; Cry32A; Cry51a \\
\hline Dipteras & $\begin{array}{l}\text { Cry1A-C; Cry2A; Cry4A-B; Cry10; Cry11A-B; Cry16A; Cry19A-B; Cry20A; } \\
\text { Cry24C; Cry27A; Cry32B-D; Cry39A; Cry44A; Cry47A; Cry48A; Cry49A }\end{array}$ \\
\hline Coleópteras & Cry1B,I; Cry3A-C; Cry7A; Cry8A-G; Cry9D; Cry14A \\
& Cry18A; Cry22A; Cry23A; Cry34A-B; Cry35A-B; Cry36A; Cry37A; Cry43A; \\
& Cry55A \\
\hline Hyemiptera & Cry2A; Cry3A; Cry11A \\
\hline Hymenoptera & Cry3A; Cry5A; Cry22A \\
\hline Rhabditida & Cry5A-B; Cry6A-B; Cry12A; Cry13A; Cry14A; Cry21A; Cry55A \\
\hline Câncer humano & Cry31A; Cry41A; Cry42A; Cry45A; Cry46A \\
\hline
\end{tabular}


Através do alinhamento das sequências de aminoácidos da classe de proteínas Cry, Hofte \& Whiteley (1989) compararam as sequências de aminoácidos de diferentes proteínas Cry conhecidas. Essa análise demonstrou que a maioria das sequências apresentava cinco blocos conservados na região amino-terminal, região que codifica a toxina ativa, intercalado por regiões de sequências variáveis (Knowles, 1994). Em 1998, Schnepf e colaboradores descreveram ainda, a presença de outros três blocos localizados na região da toxinas. Todos esses achados sugerem que esses blocos conservados são importantes para o desempenho do papel biológico das proteínas Cry, formando uma família de proteínas com estrutura e mecanismos de ação semelhantes. (Monnerat \& Bravo, 2000).

A família de proteínas Cry foi dividida em grupos em que foram organizados de acordo com a identidade dessas sequências (Figura 1). O primeiro grupo é formado pelas proteínas Cry1, Cry3, Cry4, Cry7, Cry8, Cry9 e Cry10, onde estas apresentam serem muito relacionadas e suas toxinas ativas compartilham cinco blocos de significativa homologia (Hofte \& Whiteley, 1989; Lereclus et al, 1993). O segundo grupo é formado pelas proteínas Cry5, Cry12, Cry13, Cry14 e Cry21, que apresentam homologia entre os blocos 1, 2, 4 e 5, porém no bloco 1 encontra-se uma variabilidade em relação aos grupos 1 e 2 . As proteínas do segundo grupo apresentam uma variante no bloco 2 e o terceiro bloco completamente ausente (Schnepf et al., 1998). Para ambos os grupos, quando a proteína apresenta a região C-terminal, os blocos 6,7 e 8 estão invariavelmente presentes. O terceiro grupo é formado pelas proteínas Cry2, Cry11 e Cry18, constituído pelo bloco 1 e uma variante truncada do bloco 2, mas existindo significativa homologia com os outros blocos conservados (Lereclus et al., 1989). 


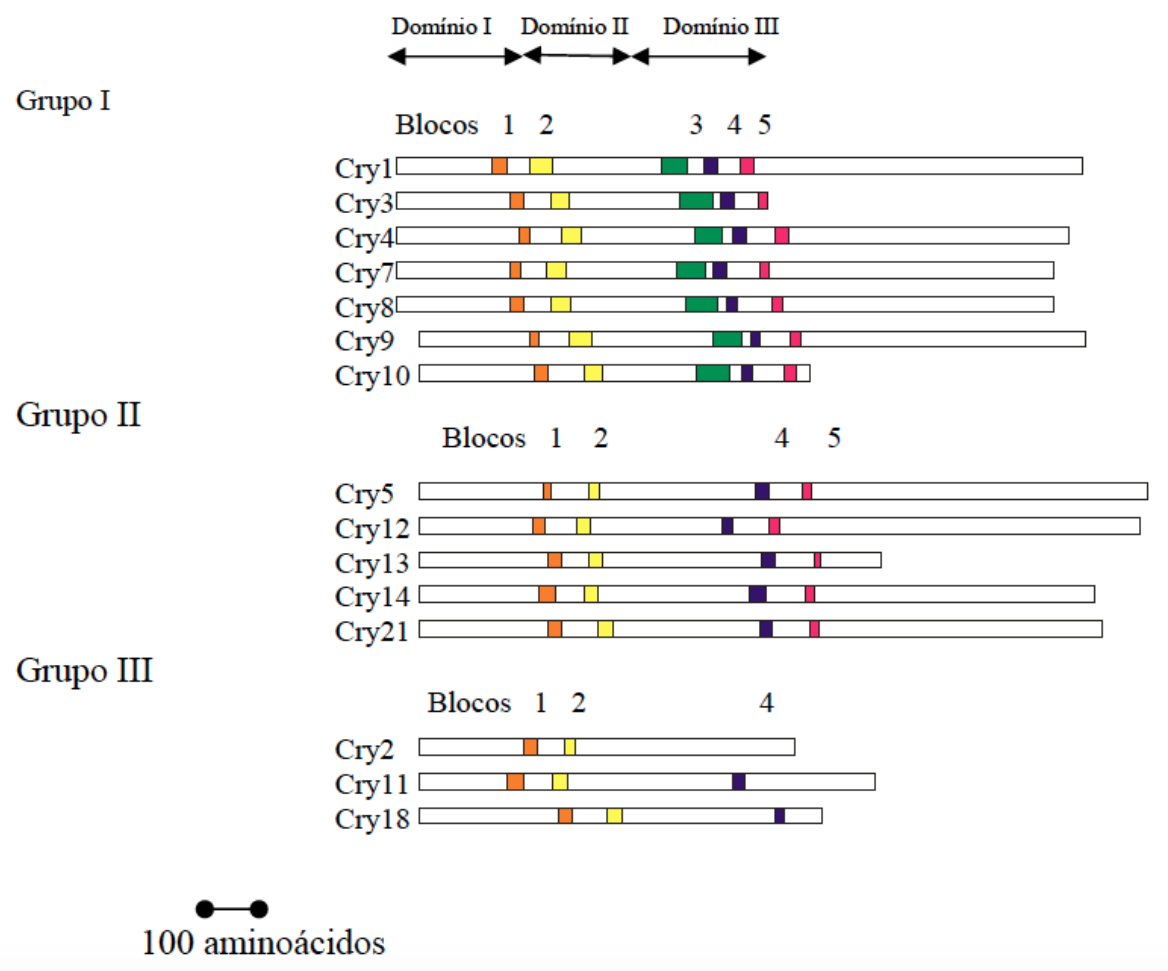

Figura 1 Alinhamento das estruturas primárias das toxinas Cry de Bacillus thuringiensis. A figura mostra os comprimentos relativos de cada proteína Cry e a posição dos blocos conservados, onde os retângulos coloridos correspondem aos blocos conservados. Adaptado de Maagd et al.,2001.
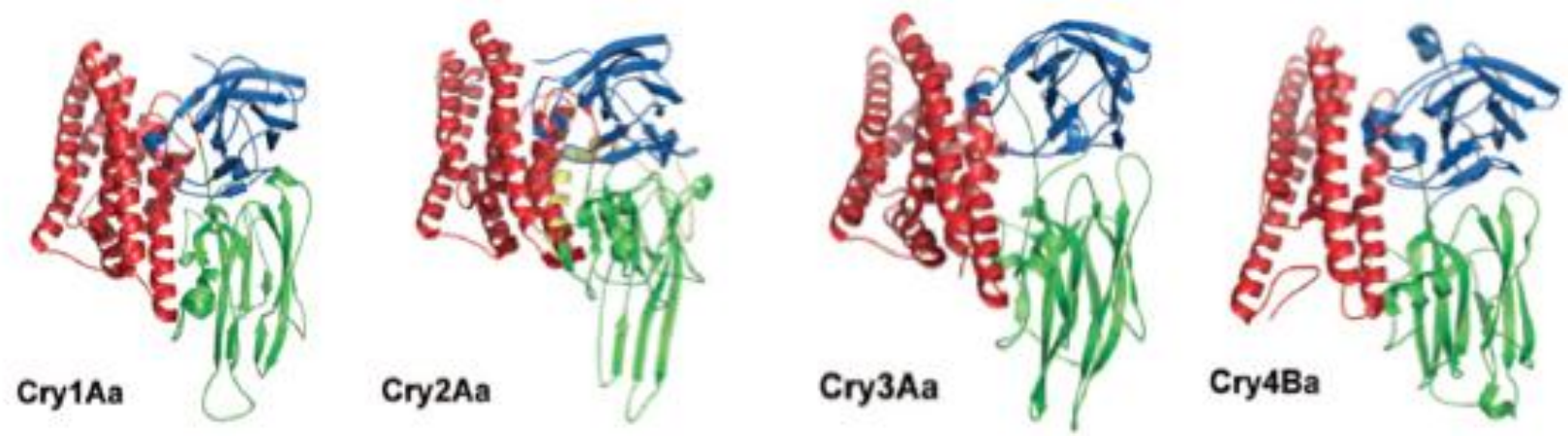

Figura 2 Representação da estrutura de três domínios de proteínas Cry. Na figura estão representadas a estrutura de três domínios das proteínas Cry1Aa, Cry2Aa, Cry3Aa e Cry4Ba respectivamente, onde em vermelho é mostrado o domínio I, responsável pela formação de poros, em verde o domínio II, responsável pela ligação a receptores de membrana, e em azul o domínio III, responsável pela estabilidade estrutural e ligação ao receptor. Adaptado de Pigott \& Ella, 2007. 


\subsection{Estrutura tridimensional das proteínas Cry}

As estruturas de algumas proteínas Cry foram obtidas por técnicas de cristalografia e difração de raios-X (Li et al., 1991; Rochulski et al., 1995) e mostraram a presença de três domínios. Membros da família de três domínios apresentam-se em um grande grupo de proteínas Cry, as quais são moléculas globulares contendo uma estrutura de três domínios conectados (Figura 2).

O domínio N-terminal, conhecido como domínio I, apresenta-se como um conjunto de sete $\alpha$-hélices, onde a $\alpha 5$-hélice central e hidrofóbica é circundada pelas outras $6 \alpha$-hélices anfipáticas. Este domínio apresenta uma similaridade com o domínio de formação de poros de duas toxinas pertencentes à família $\alpha$-PFT's, sendo as toxinas colicina Ia e $\mathrm{N}$ e difteria, por esse motivo sugere-se que este domínio seja responsável pela inserção e a formação de poros na membrana (Bravo et al., 2005). O domínio central (domínio II), é composto por três folhas $\beta$ antiparalelas que tem como função, a interação toxina-receptor (ligação ao receptor). Apresenta similaridades estruturais com várias proteínas ligantes de carboidratos como vitelina (vitelline), lectina (lectin), jacalina (jacalin) (Maagd et al., 2003). Domínio C - terminal (domínio III) é composto por um sanduíche de duas folhas $\beta$ antiparalelas e está relacionado com o reconhecimento do receptor e a inserção na membrana. Ambos os domínios, II e III são responsáveis pela especificidade do hospedeiro (Bravo et al., 2007). O domínio C terminal, também tem como papel importante, além de ajudar no reconhecimento do receptor, a formação do cristal (De Maagd et al., 2001).

\subsection{Modo de ação das proteínas Cry}

O estudo do modo de ação de proteínas Cry sempre foi um assunto central no meio científico com o intuito de tentar compreender a ligação com receptores e a inserção da toxina na membrana celular do inseto. Hoje, o modelo que temos de como 
ocorre a ação de proteínas Cry ainda não é completo, mas se deve, principalmente, a estudos em insetos da ordem Lepidoptera. (Bravo et al., 2007). O mecanismo de ação das proteínas Cry pode ser dividido em várias etapas, porém de acordo com os achados, há dois modelos muito bem aceitos.

\subsubsection{Modo de ação por formação de poros}

Esse modelo foi estabelecido baseando-se no conhecimento da interação entre a proteína Cry1 Ab e a vesículas derivadas da membrana de células do intestino ("brush border membrane vesicles - BBMV)“ de Manduca sexta. O modelo proposto é composto de uma sequência de etapas que levam à lise das células epiteliais do intestino médio do inseto através da formação de poros na membrana celular (Bravo et al., 2005). Proteínas Cry são produzidas como protoxinas, e uma vez que são ingeridas pela larva chegam ao intestino médio do inseto onde ocorre a solubilização das inclusões cristalinas devido ao ambiente alcalino. Essas proteínas solubilizadas são clivadas proteoliticamente em suas porções $\mathrm{N}$ - e/ou C- terminais por proteases presentes, ocasionando a ativação das mesmas, tornando-as toxinas ativas. Protoxinas grandes como Cry1 Aa com massa molecular de $130 \mathrm{kDa}$ perdem metade da região $C$-terminal e 20 a 50 aminoácidos do final da região $N$-terminal, e protoxinas pequenas, como a proteína Cry2Aa, são processadas principalmente no final da região $N$ - terminal (Gómez et al., 2006). A figura 3 mostra de forma esquemática a representação dos sítios de clivagem nas protoxinas Cry. 


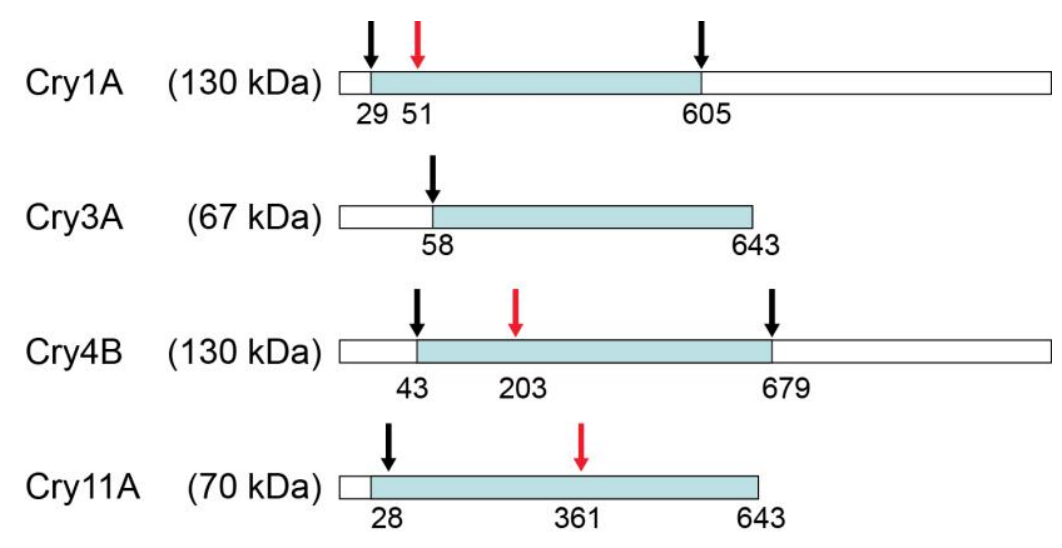

Figura 3. Representação esquemática dos sítios de clivagem por proteases em algumas proteínas Cry de $B$. thurigiensis. As caixas brancas representam os fragmentos clivados da protoxina e as caixas em azul claro indicam os fragmentos ativos, gerados após a clivagem proteolítica. As setas pretas indicam os sítios de clivagem nas porções N-terminal e C-terminal, e as setas vermelhas indicam sítios de clivagem intramoleulares (Figura adaptada de Bravo et al., 2007).

Após o processo de clivagem das toxinas, estas são inseridas na membrana celular, porém antes que essa etapa aconteça é necessário que as mesmas liguem-se a receptores específicos localizados nas microvilosidades das membranas apicais das células colunares dos insetos suscetíveis das ordens Lepidoptera (Hoffmann et al., 1988a), Coleoptera (Bravo et al., 1992) Diptera (Hofte \& Whiteley, 1989).

Há quatro tipos específicos de receptores (figura 4) descritos em lepidópteros, sendo eles, uma proteína tipo caderina (CADR), uma aminopeptidase-N (APN) ancorada a glicosilfosfatidil-inositol (GPI), uma fosfatase alcalina (ALP) ancorada a GPI, e um glicoconjugado de $270 \mathrm{kDa}$. APN e ALP ancorados a GPI encontram-se dentro de jangadas lipídicas ("'Lipid Rafts") formando pequenos domínios na membrana celular (Griffits et al., 2005; Martins et al., 2010). 


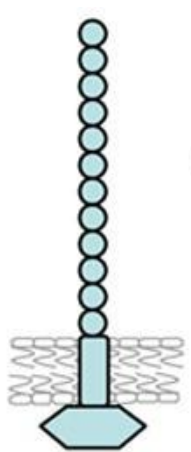

CADR

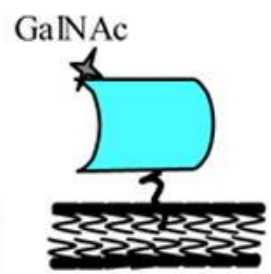

APN

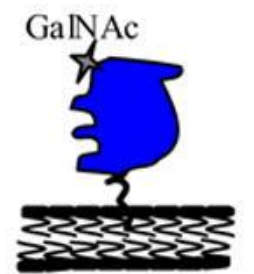

ALP

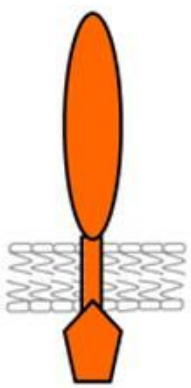

GCR

Figura 4 Receptores moleculares da proteína Cry1Aa. CADR, receptor do tipo caderina; APN, receptor aminopeptidase-N; ALP, receptor fosfatase alcalina; GCR, receptor glicoconjugado de $270 \mathrm{kDa}$ (Bravo et al., 2007)

A proteína Cry1A, usada como modelo de estudo em lepidópteros, após sofrer clivagem proteolítica por proteases do inseto, liga-se fortemente às proteínas tipo caderina (Bt-R1, tipo de receptor encontrado no modelo de estudo Manduca sexta) e APN (Juaréz et al., 2008). A proteína Cry liga-se fortemente a esses abundantes receptores, porém essa ligação é fraca para promover a localização e concentração de toxinas ativas, sendo necessário que a mesma se ligue a receptores secundários (Bravo et al., 2011). Após ligar-se ao receptor primário, a toxina sofre uma clivagem específica na região N- terminal. Essa clivagem resulta na eliminação da hélice alfa-1, presente no domínio I, o que resulta na formação de uma estrutura oligomérica, conhecida como pré-poro, importante para a inserção na membrana (Gómez et al., 2002; Bravo et al., 2007). Em seguida, o pré-poro liga-se a um segundo receptor do tipo APN ancorado a um glicolipídio (glicosilfosfatidilinositol-GPI), com alta afinidade de ligação, permitindo que a estrutura oligomérica seja inserida na membrana, levando então a formação de poros e consequentemente a lise celular (Zhuang et al., 2002; Soberón et al., 2009) (figura 5). 


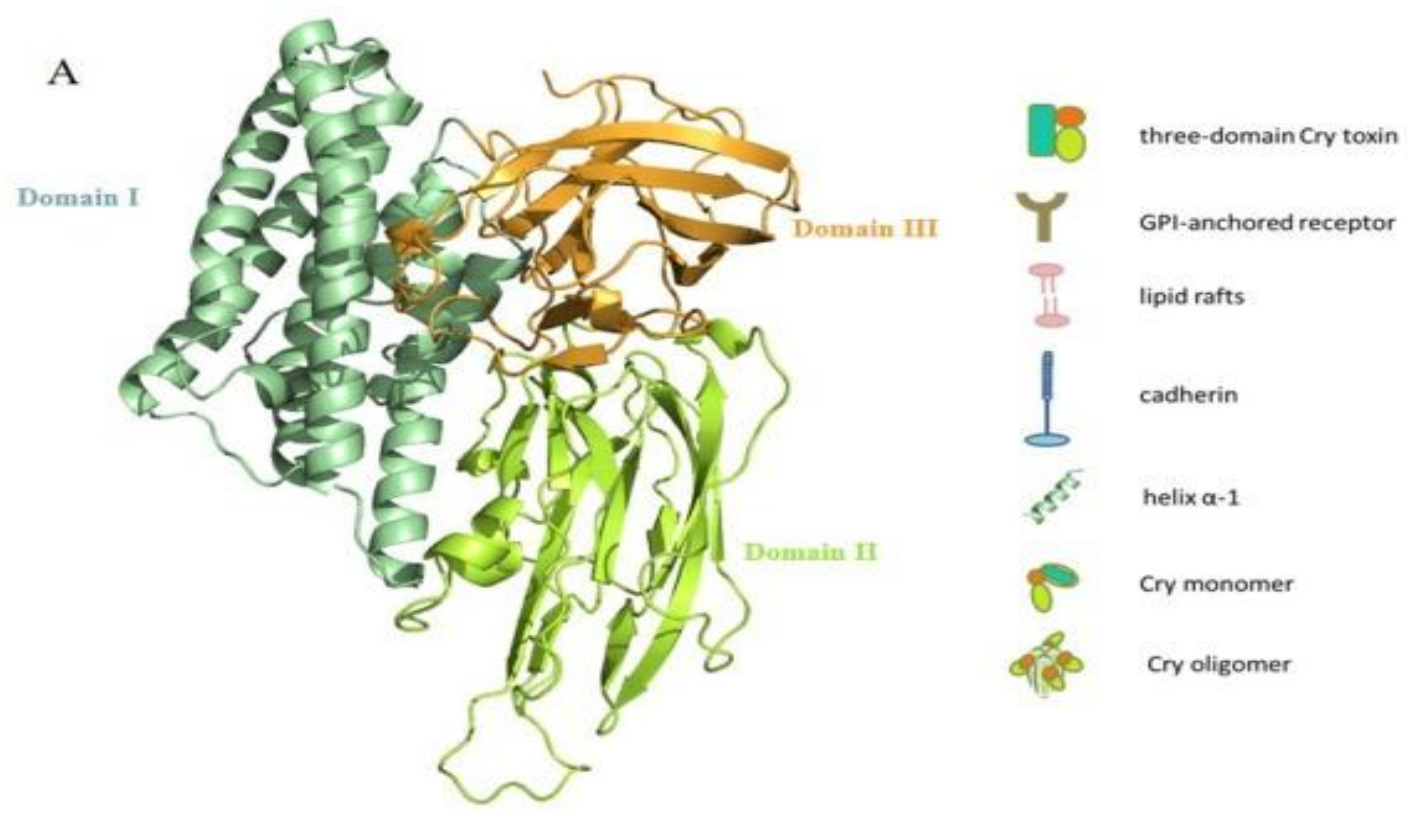

B

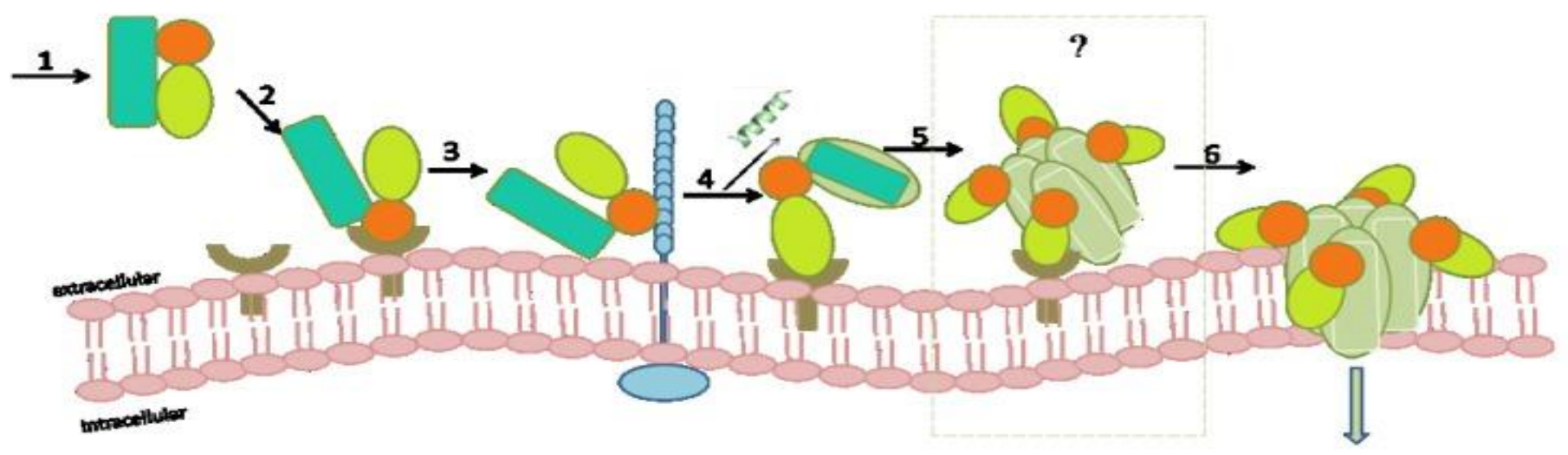

Figura 5 Modo de ação de proteinnas Cry1A por formação de poros na membrana. (A) Estrutura de três domínios da proteinna Cry, onde o domínio I está representado em verde, domínio II em verde limão e o domínio III em laranja, respectivamente. (B) Etapas sequências do modelo de formação de poros. 1 - Proteína Cry1A solubilizada é digerida por proteases no ambiente alcalino do inestino médio do inseto; 2 - Cry1Aa liga-se ao abundante receptor APN ancorado a GPI e ALP nas jangadas lipídicas. 3 - Ligação ao receptor caderina facilita a clivagem proteolítica na $\alpha 1$ hélice na porção N-terminal; 4 - A clivagem em N-terminal induz a formação do oligômero aumentando a afinidade de ligação aos receptors; 6 - O oligômero é inserido na membrana levando a formação poro e a lise celular (Xu et al., 2014). 


\subsubsection{Modo de ação por transdução de sinal}

Em 2005, Zhang e colaboradores questionaram o modo de ação proposto anteriormente, sendo assim propuzeram o modo de ação baseado na transdução de sinais, onde citotoxicidade é mediada pela ligação específica de monômeros da toxina Cry em receptores caderina $\left(B T-R_{1}\right)$, uma vez que essa ligação ativa uma cascata de sinalização dependente de $\mathrm{Mg}^{2+}$, promovendo então a morte celular. Além disso, foi sugerido também que a ligação específica ao receptor do tipo caderina pode ativar a via de sinalização mediado pela ativação de uma proteína $G$ e uma adenilato ciclase, levando a um aumento nos níveis de AMP cíclico (cAMP), e consequentemente a ativação da proteína quinase A (PKA). Essa cascata de sinalização resulta em uma desestabilização do citoesqueleto e dos canais iônicos e como consequência leva a morte celular (Zhang et al., 2006)

\subsection{Proteínas Cyt}

Proteínas Cyt (citolíticas) são proteínas formadoras de cristais produzidas por $B$. thuringiensis, porém não possuem nenhuma relação estrutural com proteínas Cry, não apresentando nenhuma homologia de sequência de aminoácidos. Ao contrário das proteínas Cry, as quais apresentam um espectro de atividade inseticida para Lepidopteros e Coleopteros, proteínas Cyt apresentam atividade tóxica apenas para dipteros, no caso de mosquitos e borrachudos, mas também apresentam toxicidade para células de mamífero in vitro, quando em grande quantidade (Butko, 2003).

O grupo de proteínas Cyt é bem menor em relação ao grupos das proteínas Cry, sendo classificado com base no Comitê de Nomenclatura de toxinas de B. thuringiensis (Bacillus thuringiensis Toxin Nomenclature Avaiable online: http://www.lifesci.sussex.ac.uk/Home/Neil_Crickmore/Bt/), apenas em três famílias, 
como Cyt1 (1Aa, 1Ab, 1Ab, 1Ac e 1Ad), Cyt2 (2Aa, 2Ba, 2Bb, 2Bc e 2Ca) e Cyt3 (3Aa1) (Crickmore et al., 1989).

A família de proteínas Cyt tem como estrutura apenas um único domínio com uma arquitetura $\alpha-\beta$ com folhas- $\beta$ ao centro cercadas com duas camadas de $\alpha$-hélices. A folha- $\beta$ consiste em 6 folhas- $\beta$ antiparalelas flanqueadas por uma camada de $\alpha$ - hélice compostas de $\alpha 1$ e $\alpha 2$ de um lado e do outro lado, $\alpha 3-\alpha 5$ (figura 6) (Cohen et al., 2008; Cohen et al., 2011; Li et al., 1996). As toxinas Cyt são estruturalmente relacionadas com volvatoxina A2. Volvatoxina é uma toxina cardiotóxica isolada de do cogumelo comestível, Volvariella volvacea, em que causa parada cardíaca através da ativação de ATPase $\mathrm{Ca}^{2+}$ dependente na fração microssomal ventricular, resultando em hemólise dos glóbulos vermelhos de humanos, e na citotoxicidade para células tumorais e mitocôndrias das células do fígado (Lin et al., 2004) (Wu et al., 2006). Através do alinhamento das sequências de aminoácidos de proteínas Cyt revela-se que há quatro blocos bem conservados entre elas, sendo o bloco I a hélice $\alpha 1$; o bloco II, a região de $\alpha 5$ a $\beta 5$; bloco III, região $\beta 6-\beta 7$; IV bloco 4 , região $\alpha 6-\beta 8$ (Butko, 2003).

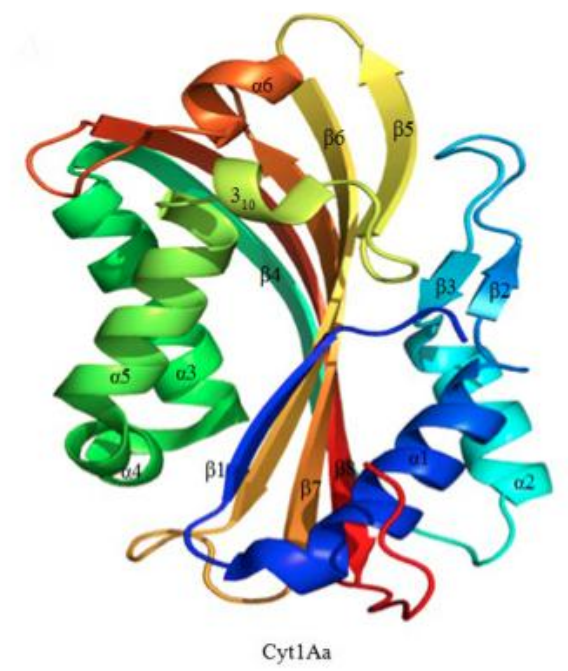

Figura 6 Representação estrutural de proteína Cyt. Domínio único da toxina Cyt comport por uma arquitetura $\alpha / \beta$ com uma folha - $\beta$ central cercada por duas $\alpha$ - helices. A folha $-\beta$ cebtral consiste em seis folhas $-\beta$ antiparalelas com duas $\alpha$-helices (Xu et al., 2014) 


\subsubsection{Modo de ação das proteínas Cyt}

Proteínas Cyt são sintetizadas como protoxinas e quando ingeridas pelo inseto são solubilizadas no intestino do inseto susceptível devido ao $\mathrm{pH}$ alcalino e ativadas proteoliticamente pela ação de proteases do intestino médio, produzindo então toxinas ativas de $25 \mathrm{kDa}$ (Li et al., 1991). As toxinas Cyt ativadas não são capazes de se ligar a receptores localizados na membrana de células do intestino médio dos insetos, interagindo então com fosfolipídeos, como a fosfatidilcolina, fosfatidiletanolamina e esfingomielina. Existem duas hipóteses que explicam a inserção de toxinas Cyt nas células o intestino médio: (1) modelo de formação de poros onde toxina Cyt se liga na membrana celular, induzindo a formação de canais seletivos de cálcio em vesículas da membrana, conduzindo à lise osmótica da célula (de Maagd et al., 2003; Griffits et al., 2005) e (2) um modelo de efeito detergente que propõe uma agregação não-específica da toxina na superfície da bicamada lipídica levando a desmontagem e morte celular (Butko, 2003) (Figura 7).
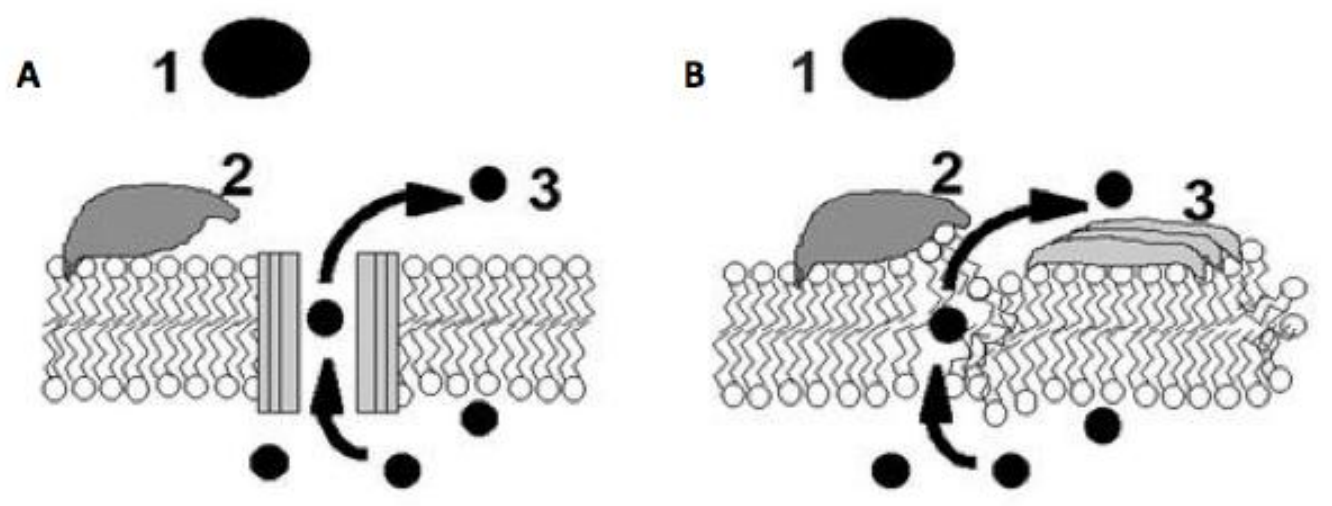

Figura 7 Representação dos dois possíveis modelos de ação de proteínas Cyt. (A) Modelo por formação de poros: 1 - Solubilização da proteína; 2 - Ligação e inserção da proteína na bicamada lipídica; 3 - Formação do poro e disfunção osmótica. (B) Modelo detergente: 1 - Solubilização da proteína; 2 - Ligação da proteína na superfície da bicamada lipídica; 3 - Formação de agragados lipídicos e destruição da membrana plasmática (Butko, 2003). 


\subsection{Parasporinas}

Historicamente, acredita-se que B. thuringiensis foi caracterizados por terem sua atividade inseticida associada com suas inclusões cristalinas, embora alguns estudos tenham demonstrado o contrário, onde novas estirpes de B. thuringiensis com inclusões cristalinas foram isoladas do solo e não apresentaram atividade inseticida para os insetos testados (Hastowo et al. 1992; Meadows et al. 1992; Roh et al. 1996). Sendo assim, essas novas estirpes foram classificadas como estirpes produtoras de inclusões paraesporais não-inseticidas.

Com o intuito de investigar o fato das novas estirpes de B. thuringiensis apresentarem tal característica, a partir do ano de 1996 vários estudos baseados na triagem dessas novas proteínas Cry não-inseticidas foram realizados, o que levou a descoberta de proteínas com toxicidade seletiva para células de câncer humano. Em 1999, Mizuki e seus colaboradores demonstraram o primeiro trabalho em que inclusões proteicas não-inseticidas de $B$. thuringiensis apresentaram toxicidade para células de câncer humano, sendo feita uma triagem com 1.744 (mil quatrocentos e quarenta e quatro) cepas de B. thuringiensis contra eritrócito de ovelha, onde 60 (sessenta) induziram uma alta hemólise. A atividade tóxica para células MOLT - 4 (células - T de leucemia humana) das outras 1.684 ( mil seiscentos e oitenta e quatro) cepas sem atividade hemolítica foram analisadas e 42 cepas mostraram-se tóxicas.

Contudo, novos estudos começaram a ser feitos e estes têm mostrado que estirpes de B. thuringiensis isolados do ambiente produzem inclusões proteicas não inseticidas, que apresentam proteínas denominadas parasporinas (PS), não apresentando atividade inseticida, nem hemolítica, como as proteínas Cry e Cyt (Saitoh, 2006). Mizuki et al. (2000) descreveram essa nova toxina em uma linhagem de $B$. thuringiensis, sendo definida como uma proteína paraesporal de B. thuringiensis, sem atividade hemolítica e que apresentam toxicidade para células cancerígenas em geral 
(Ohba et al., 2008). Estas são atualmente classificadas pelo Comitê de Classificação e Nomenclatura de Parasporinas (http//parasporin.fitc.pref.fukuoka.jp/index.html) em seis grupos (PS1, PS2, PS3, PS4, PS5 e PS6) de acordo com o grau de identidade de suas sequências de aminoácidos (Ohba , 2011).

\subsubsection{Parasporina -1}

Em 2005, Katayama e colaboradores isolaram, a partir da estirpe A1190 de Bacillus thuringiensis, a primeira Parasporina, denominada Parasporina - 1 (PS1). A estirpe A1190 produz inclusões não inseticidas compostas de uma protoxina que apresenta tamanho $81 \mathrm{kDa}$ e quando esta sofre ativação proteolítica por tripsina produz dois fragmentos, sendo um de $15-$ e outro de 56-kDa, formando um complexo ativo, ou seja, estes fragmentos são os responsáveis pela atividade tóxica da proteína PS1 quando em cultura, por mais de 20 horas, com células tumorais Hela (câncer cervical), células HL60 (leucemia promielocítica humana) e MOLT-4 ( célula leucêmica humana) apresenta atividade tóxica, levando a morte destas e a presença de alterações morfológicas nas células, como inchaço e fragmentação celular (Katayama et al., 2005).

Como é sabido, proteínas Cry tem como mecanismo de ação a formação de poros na membrana celular, ocasionando o aumento da permeabilidade da membrana, o que leva à morte do inseto. Diferentemente do modo de ação de proteínas Cry, PS1, quando incubada com células Hela não afeta a permeabilidade da membrana celular, o que foi mostrado por Katayama e colaboradores em 2007, após um ensaio em que células Hela, tratadas com PS1 não apresentam vazamento de LDH (lactato desidrogenase) e nem o efluxo de PI (iodeto de propídeo), diferentemente de quando as mesmas células são tratadas com streptolisina O de Streptococcus pyogenes. No mesmo trabalho, os autores demonstraram que PS1 é capaz de causar um influxo de cálcio no interior da célula, que está diretamente relacionado com a toxicidade da proteína. $\mathrm{O}$ cálcio intracelular é um importante regulador da apoptose celular, este leva a ativação 
de proteínas envolvidas na cascata de ativação da morte celular programada, como a caspase-3, ou seja, sugere-se que a PS1 induza a célula a apoptose.

\subsubsection{Parasporina -2}

Parasporina - 2 (PS2) foi primeiramente descoberta em uma estirpe de $B$. thuringiensis A1547, a qual pertence a B. thuringiensis serovar Dakota (H15) (Kim et al., 2000). Ito e colaboradores (2004) demonstraram que PS2 quando produzida é encontrada na sua forma ativa como uma proteína de $37 \mathrm{kDa}$, a qual apresenta uma limitada similaridade de sequência com a maioria das proteínas Cry e Cyt descritas anteriormente, porém apresenta 23,5\% de identidade nas sequências de aminoácidos com Cry15Aa, proteína que pertence à família de toxinas da espécie B. sphaericus. Quando sofre ativação proteolítica pela enzima proteinase K perde 51 e 36 resíduos de aminoácido nas porções $\mathrm{N}$ - e C- terminal, produzindo um fragmento ativo de $30 \mathrm{kDa}$. Quando a forma ativa é exposta a células tumorais dos tipos MOLT-4, Jurkast (Células T leucêmicas), Sawano (células de câncer uterino), HepG2 (células de câncer hepatócito humano), MCF-7 (células de câncer de mama humano), MDA-MB-231 (célula de câncer de mama humano invasivo), PC-3 (célula de câncer de próstata) e Caco-2 (célula de câncer de colo) apresentam uma alta toxicidade levando a morte das células após o tratamento por 24 horas (Ito, A et al., 2004; Brasseur et al., 2015).

Por meio da técnica de cristalografia de raio $-\mathrm{X}$ foi possível determinar a estrutura cristalográfica da PS2, mostrando que esta é uma proteína com estrutura de 3 domínios (Akiba et al., 2009) como as proteínas Cry citadas anteriormente. Por esse motivo, a PS2 foi enquadrada na grande família de toxinas formadoras de poros $(\beta-$ PFT), representada por aerolisinas de Aeromas hydrophila, que é uma toxina capaz de matar células susceptíveis através de formação de poros na membrana plasmática 
(Rossjohn et al., 1998) sugerindo que esta toxina apresente um mecanismo de ação característico ao mecanismo de formação de poros na membrana.

Estudos ainda estão sendo feitos para desvendar melhor como se dá o mecanismo de ação de proteínas PS2 em células tumorais. Inicialmente foi mostrado que a toxina se liga à membrana da célula susceptível por meio de receptores, não descritos até o momento. Após a ligação ao receptor, a toxina ativa é organizada na superfície da membrana na forma de oligômeros. Esses complexos oligoméricos são formados em regiões da membrana, as jangadas lipídicas, que são estruturas localizadas nos micro domínios da membrana plasmática, e que apresentam um papel importante na sinalização de proteínas, ocasionando a formação de poros na membrana e a consequente lise celular ocasionando em sua morte (Ito, et al., 2004; Kitada et al., 2006, Akiba et al 2009). Porém, em 2015, Kevin Brasseur e colaboradores mostraram que o mecanismo de ação de PS2 está vinculado à morte celular programada. Isolaram PS2 (Cry46) a partir da estirpe 4R2 de B. thuringiensis e mostraram, através de microscopia que células HepG2, MCF-7 e Caco-2 não apresentavam mudanças morfológicas como, inchaço celular, formação de bolhas, lise da célula, desestabilização dos microtúbulos e filamentos de actina, fragmentação da mitocôndria e retículo endoplasmático que haviam sido mostradas anteriormente (Ito et al., 2004; Kitada et al., 2006, Akiba et al 2009), pelo contrário, mostraram que as células tratadas apresentavam característica de encolhimento, supondo então que PS2 possa induzir apoptose em células cancerígenas. Diante desses resultados, estudaram essa hipótese e chegaram a conclusão de que PS2 é capaz de ativar a cascata de caspases que leva a morte celular programada.

\subsubsection{Parasporina -3}

A parasporina - 3(PS3) foi identificada em uma única estirpe de B. thuringiesis A1462, isolada de solo japonês (Mizuki et al., 1999a). Duas protéinas (PS3Aa1 e 
PS3Ab1) foram identificadas e bioensaios mostraram que essas proteínas não apresentavam toxicidade para insetos. Ambas as proteínas apresentam massa molecular de $88 \mathrm{kDa}$ e da mesma forma que as outras protoxinas de $B$. thuringiensis, precisam ser clivadas proteoliticamente para tornarem-se toxinas ativas, sendo assim, quando são clivadas por proteinase $\mathrm{K}$ em sua porções $\mathrm{N}$ - terminais, formas ativas da toxina com massa molecular de $64 \mathrm{kDa}$ são produzidas (Yamashita et al., 2000). Em 2005, Yamashita e colaboradores mostraram que as duas toxinas PS3 apresentaram atividade tóxica para células HL60 e HepG2, sendo que em células HepG2 foi observado que, quando tratadas com as toxinas havia vazamento de lactato desidrogenase (LDH), o que indica que essas toxinas causam permeabilidade de membrana, sugerindo que seu mecanismo de ação seja por formação de poros na membrana. Mostraram também, através da análise de sequência que as proteínas, PS3Aa1 e PS3Ab1) apresentam 88\% de homologia de sequencia e estas, apesar de apresentarem baixa similaridade com proteínas Cry e Cyt, apresentam cinco blocos de regiões conservadas da estrutura de três domínios de proteínas Cry, o que provavelmente permite que proteínas do grupo PS3 apresentem similaridade de ligação a receptor em células alvo, confirmando o possível mecanismo de ação de formação de poros (Ohba et al., 2009).

\subsubsection{Parasporina -4}

Parasporina - 4 (PS4), assim como as anteriormente citadas, também foi isolada a partir de uma estirpe de $B$. thuringiensis A1470. Da mesma forma precisa ser clivada proteoliticamente para torna-se uma toxina ativa, sendo assim quando tratada com proteinase $\mathrm{K}$ esta produz um fragmento ativo de $26 \mathrm{kDa}$, o qual apresenta alta citotoxicidade para células de câncer MOLT-4, CACO-2 (câncer de colo humano), Sawano, TCS (human uterus cervix câncer) e células HL60 ( Lee et al 2001; Okumura et al., 2001; Okumura et al., 2004; Saitoh et al., 2006 Okumura et al., 2008). 
Em 2011, um estudo realizado por Shiro Okumura e colaboradores foi mostrado que a PS4 é capaz de formar poros na membrana plasmática de células susceptíveis devido ao fato de ocorrer vazamento de LDH, visto que este não é capaz de atravessar a membrana, sendo liberado apenas quando ocorre lise da mesma. Observaram também, através do ensaio de Citometria de Fluxo que PS4 é capaz de se ligar a membrana plasmática das células susceptíveis, porém de forma inespecífica, sendo também capaz de formar complexos oligoméricos, no caso heptâmeros, na membrana, o que ajuda no mecanismo de ação de formação de poros.

Através da análise da sequência de aminoácidos é sugerido que a PS4 pertença a família do tipo aerolisinas $\beta$ - PFT - 'aerolysin-type $\beta$ - PFT family ', família a qual é conhecida por formar complexos oligoméricos na membrana plasmática ocasionando na formação de poros na membrana (Okumura et al., 2011), porém, apesar de pertencer a essa família a mesma não compartilha homologia de sequência com proteínas, como streptolysin O de S. pyogenes (Palmer et al., 1998), pneumolysin de Streptococcus pneumoniae (Tilley et al., 2005) e perfringolysin de C. perfringens (Czajkowsky et al., 2004), que pertencem a família citolisina colesterol - dependente 'Cholesterol dependente cytolysin (CDC)', sendo então uma proteína colesterol independente 'Cholesterol - independet'. Por essas evidências é sugerido que a PS4 seja uma proteína formadora de poros, assim como a PS2 mas que diferentemente dela, o tipo quatro da família de parasporina não é capaz de induzir a célula à apoptose (Okumura et al., 2011).

\subsubsection{Estrutura tridimensional das Parasporinas 2 e 4}

As estruturas cristalinas das proteínas PS2 e de uma proteína não tóxica (nontoxic) de $26 \mathrm{kDa}$ isolada da cepa $\mathrm{A} 1470$ de B. thuringiensis foram determinadas. A proteína de $26 \mathrm{kDa}$ foi comparada com a toxina PS4 e estas compartilham $38 \%$ de 
identidade de sequência, ou seja, essa proteína é uma proteína tipo parasporina - 4 (like parasporin -4) (Akiba et al., 2009; Akiba et al., 2006; Akiba et al., 2004), sendo assim a estrutura da PS4 foi gerada por SWISS-MODEL, onde a proteína de $26 \mathrm{kDa}$ foi usada como molde (Guex et al., 2009) (figura 8) SWISS-MODEL é uma plataforma de bioinformática que permite modelar, por homologia de sequência, estruturas tridimensionais de proteínas conhecidas, com base em sua sequência lotada em um banco de dados (Schwede et al., 2003).

Toxinas (PS2 e PS4) como mencionado anteriormente possuem uma similaridade estrutural significativa com proteínas da família das aerolisinas, sendo assim estas fazem parte da família de proteínas formadoras de poros, compartilhando semelhanças entre seus domínios estruturais (figura 8). É sugerido que o domínio I dessas proteínas esteja relacionado com o importante papel de ligação e interação com receptores ancorados a GPI (Cole et al., 2004) característica importante relacionada co mecanismo de formação de poros. Apenas no domínio I encontram-se $\alpha$-hélices, sendo quatro $\alpha$ - hélices curtas encontradas na PS2 e duas $\alpha$ - hélices separadas na proteína tipo parasporina -4. Ainda no primeiro domínio é localizado na porção N- terminal uma pequena volta em folhas - $\beta$ ( $\beta$ - hairpin) e na porção C- terminal uma parte mais longa na cadeia - $\beta$. Em proteinas tipo aerolisinas, pertencentes a grande família de $\beta$-PFTs, há a presença abundante de anéis aromáticos, os quais são responsáveis pela ligação de carboidratos, como glicose e galactose, formando a interação proteína - carboidrato, sendo uma interação importante pois esta pode contribuir para a ligação específica de várias proteínas ligantes de açúcar (Payne et al., 2011).

O domínio II da toxina PS2 é formado por quatro folhas - $\beta$ que encontram-se muito próximas ao domínio I associando-se com as hélices do domínio I através de interações hidrofóbicas. A superfície interna das quatro folhas- $\beta$ associa-se a uma volta $\beta$ ( $\beta$-hairpin) anfipática formando um núcleo hidrofóbico, onde é estabilizado por pontes 
de hidrogênio (Akiba et al., 2006; Akiba et al., 2009), onde tal disposição apresenta um papel importante para o dobramento da proteína (Schwartz et al., 2001). Nos modelos estruturais baseados em toxinas aerolisinas, o $\beta$-hairpin anfipático está relacionado com a transposição da proteína na membrana, ou seja, este domínio está intimamente relacionado com a formação de poros (Melton et al., 2004). Além disso, PS2 possui uma notável distribuição de resíduos serina e treonina hidrofóbicos nas cadeias - $\beta$ adjacentes à volta do $\beta$-hairpin (Akiba et al., 2009), o que também é encontrado em outras estruturas de proteínas da classe de $\beta$-PFTs, como por exemplo ETX, aerolisinas, $\alpha$ - toxina e MTXs (Cole et al., 2004), pontuando novamente que essas sequências participam no processo de transmembrana e reforçando o papel do domínio II como importante na formação de poros na membrana.

O domínio III tanto da PS2 como da proteína tipo parasporina - 4 de $26 \mathrm{kDa}$ consistem em uma cadeia tripla de folhas $-\beta$ antiparalelas e uma cadeia dupla de folhas $-\beta$ antiparalelas, onde essas interagem formando um sanduíche de folhas - $\beta$ (Akiba et al., 2006). Quando a toxina PS2 é clivada por ação de proteases, o final da região Cterminal da proteína é removido durante essa digestão proteolítica. No ato dessa remoção ocorre a perda de uma parte o núcleo hidrofóbico localizado no interior desse sanduíche formado pelas folhas - $\beta$, sendo este exposto, formando um pequeno trecho hidrofóbico na superfície da cadeia - $\beta$, sugerindo que essa ativação no $\mathrm{C}$ - terminal esteja relacionada com a oligomerização da toxina na membrana da célula (Akiba et al., 2009). 

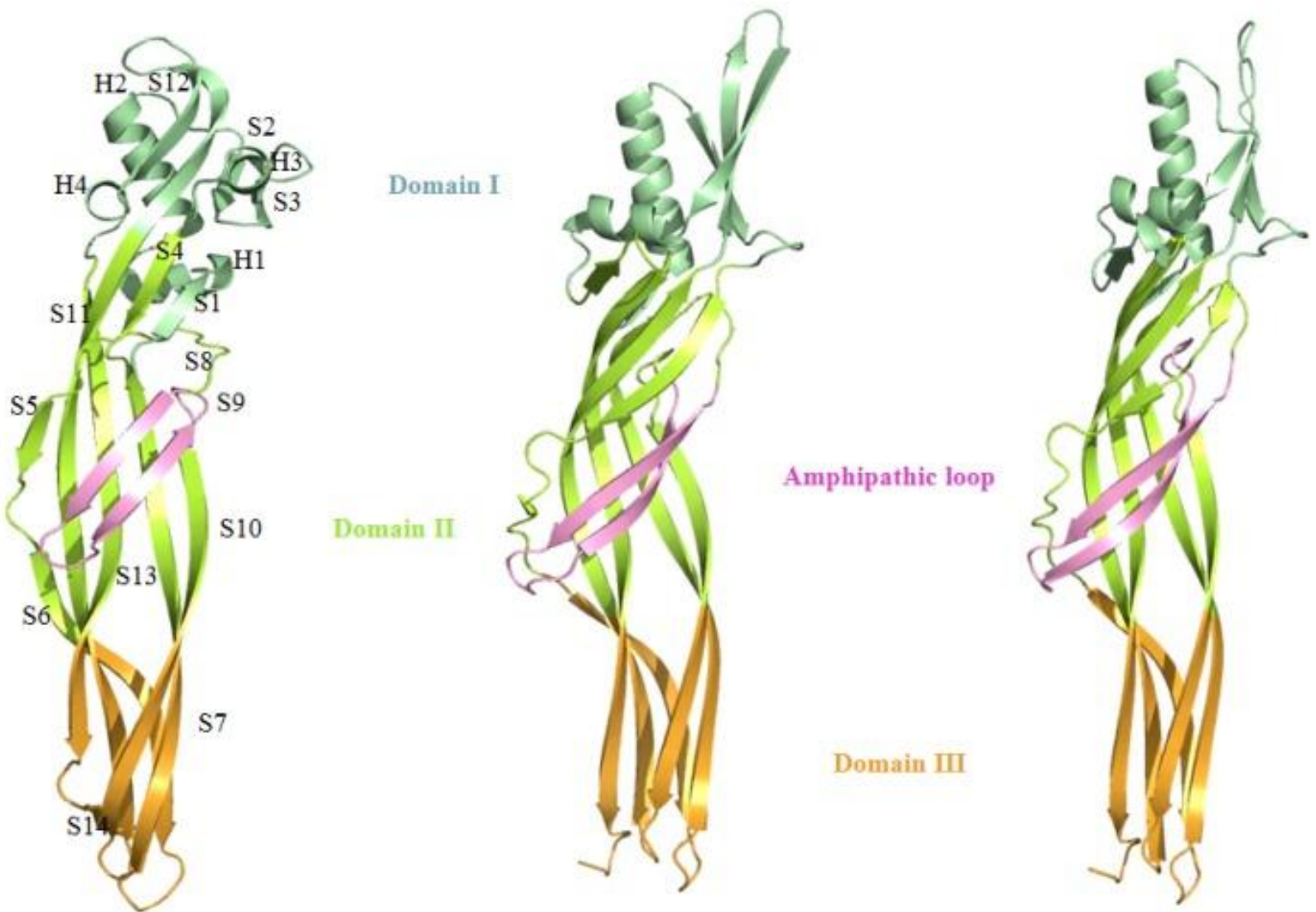

Parasporin-2

Nontoxic $26 \mathrm{kDa}$ protein

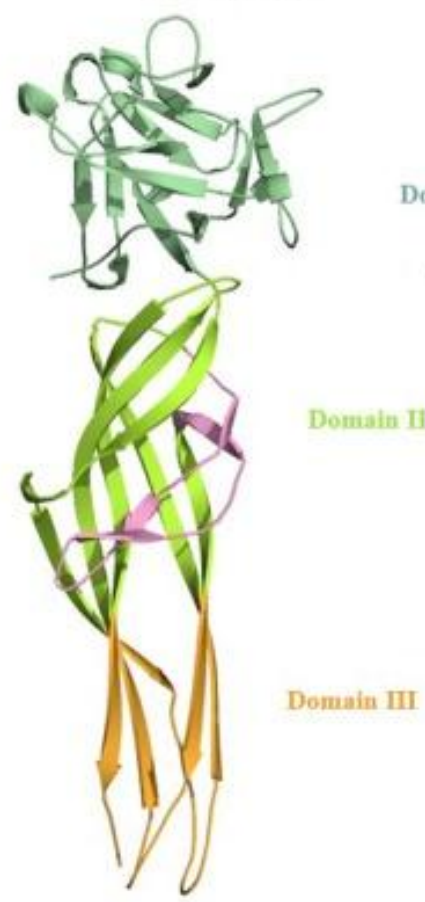

Clostridium perfringens

Enterotoxin

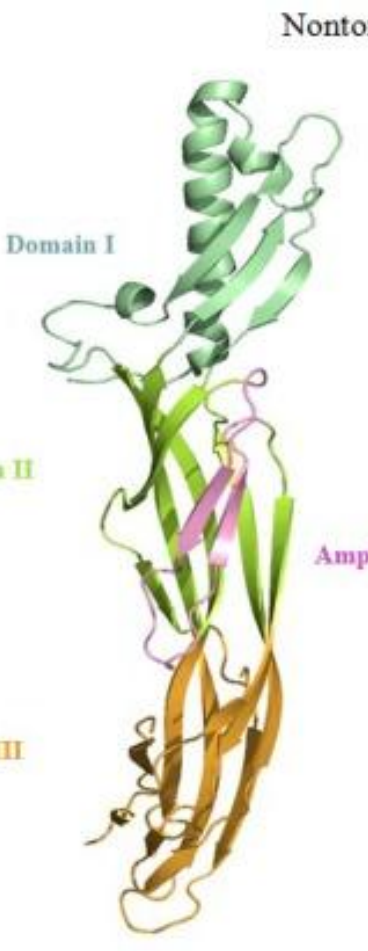

Clastridium perfringens

Epsilon toxin

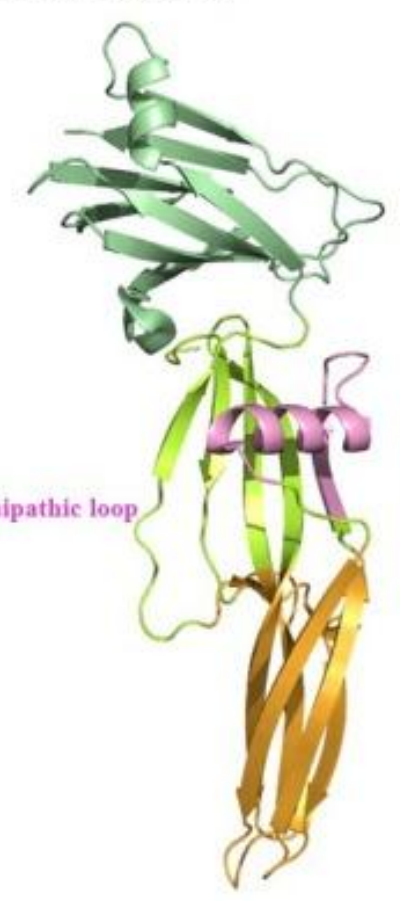

Lacctiportus sulphureus

Lectin

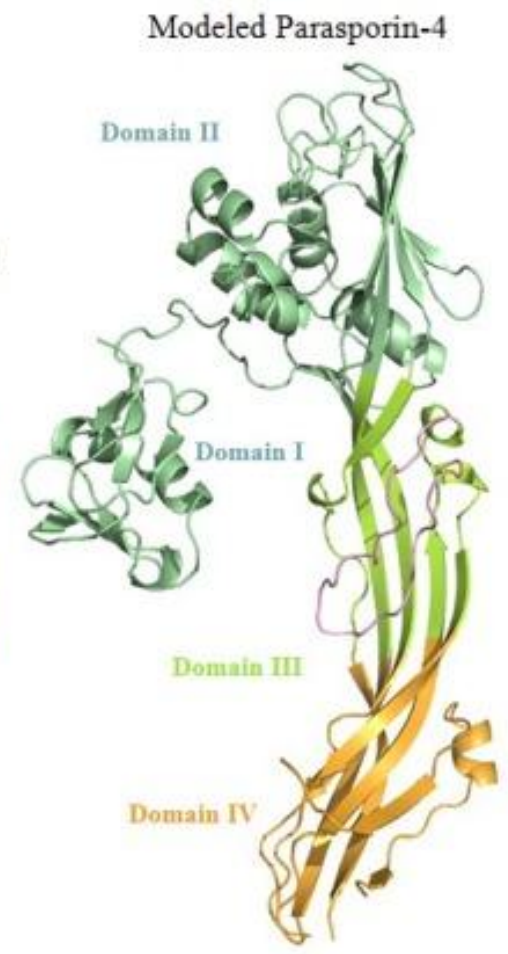

Aeromonas hydrophila

Proaerolysin

Figura 8 Comparação estrutural entre parasporina - 2, proteína não tóxica de 26 kDa e aerolisinas. Em verde claro está representado o domínio N-terminal; Em verde limao domínios relacionadas a inserção na membrana e em laranja, domínio relacionado a formação de poros. Em rosa, está o a alça - $\beta$ a qual sugere-se estar relacionada com a formação de poro (Xu et al., 2014). 


\section{Baculovírus}

Os vírus pertencentes a família Baculoviridae são capazes de infectar diversas ordens de insetos, principalmente insetos das ordens Lepidoptera, Diptera e Hymenoptara (Miller, 1997). Devido à sua alta virulência, especificidade para insetos e estabilidade no ambiente, o vírus tem sido utilizado como bioinseticida no controle de pragas agrícolas e florestais, sendo então uma boa alternativa aos pesticidas químicos (Szewczyk et al., 2009).

Além de serem usados como bioinseticida, baculovírus tem sido usado como uma importante ferramenta biotecnológica em que seu ciclo de infecção é usado como um sistema de expressão em células de inseto, tornando-se um importante sistema para produção de proteínas recombinantes, sendo também potenciais candidatos para terapia gênica (Hitchman et al., 2009; Kost et al., 2005).

\subsection{Estrutura e taxonomia}

A família Baculoviridae é composta de vírus onde o genoma é composto de DNA circular dupla - fita que varia de 80 a 180 pares de bases, e é envolto por um capsídeo protéico em forma de bastão, o que constitui uma unidade infectiva, o nucleocapsídeo. Baculovírus infectam membros do filo Artrophoda, principalmente das ordens Lepidoptera, Diptera e Hymenoptera. Apresenta-se subdividida em quatro gêneros que são classificados baseando-se nas evidências filogenéticas e características moleculares, como: Alphabaculovirus - nucleopoliedrovirus (NPVs) específicos de lepidópteras, Betabaculovírus - granulovírus (GVs) específicos de lepidópteros, Gammabaculovirus - NPVs específicos de heminópteras e Deltabaculovírus - NPVs específicos de dípteras (Jehle et al., 2006).

Durante o ciclo de infecção, as partículas virais assumem dois tipos de fenótipos distintos, mas que são geneticamente idênticos. São as formas virais, "budded vírus - 
BV" (vírus brotado) e "occlusion - derived vírus - ODV" (vírus derivado da oclusão).

O primeiro fenótipo é formado no processo de brotamento pela membrana citoplasmática da células hospedeira para o meio extracelular, infectando células vizinhas e consequentemente disseminando a infecção, sendo então responsável pela infecção horizontal. O segundo fenótipo, "occlusion - derived vírus - ODV” (vírus derivado de oclusão) é formado no núcleo da célula de inseto. Este é envolto por uma matriz protéica em uma fase tardia de infecção, formando então estruturas cristalinas chamadas de corpos de oclusão (OBs). Apesar de serem idênticos geneticamente, estes desempenham papéis diferentes durante o ciclo de infecção viral, como a forma de entrada na célula do hospeiro e infectividade.. (Blissard, 1996).

Os baculovírus apresentam suas partículas virais ocluídas por uma matriz protéica cristalina, o que forma um corpo de oclusão poliédrico, variando de 0,15 a 15 $\mu \mathrm{m}$ de diâmetro, podendo ser chamado de poliedro, composto por subunidades de poliedrina, uma proteína com de cerca de 29.000 daltons, que corresponde a $95 \%$ do conteúdo protéico do OB (Braunagel et al., 2003; Maruniak, 1986). .

A oclusão dos vírus é de muita importância para garantir proteção à partícula viral na transmissão dos vírus de inseto para inseto (Blissard \& Rohrmann, 1990), visto que estes são altamente estáveis, podendo sobreviver no ambiente ao longo de décadas. (Braunagel et al., 2003).

\subsection{Baculovírus como vetor de expressão (BEV)}

Baculovírus são também usados como vetor de expressão de proteínas heterólogas (BEV) em células de insetos (in vitro) e em insetos (in vivo) (Castro et al., 1999). O BEV é bastante usado para a expressão de proteínas heterólogas derivadas de agentes patogênicos para desenvolvimento de vacinas e para diagnose, além do seu uso 
potencial na terapia gênica como agentes de entrega de genes, pois são capazes de transduzir células de mamíferos (O’Reilly et al., 1992).

A expressão gênica viral acontece em cascata e é dividida em duas fases, sendo a primeira, fase precoce (early), onde os eventos ocorrem antes da replicação do DNA viral e a segunda, fase tardia (late), expressão de genes pós-replicação do DNA viral (Blissard \& Rohrmann, 1990). A produção de proteínas responsáveis pela construção de BV, são produzidas no início da fase tardia, de 6-15 horas pós infecção, quando ocorre a replicação do DNA viral e montagem das partículas BV (Lu \& Miller, 1997). A poliedrina, é a principal proteína de um corpo de oclusão proteico (também denominado de poliedro ou $\mathrm{OB}$ ), que é produzido no núcleo das células infectadas, na fase tardia da infecção e contem as partículas ODV no seu interior (Rohrmann, 1986). A poliedrina é altamente expressa durante a infecção viral e não é essencial para replicação viral. Desta forma, a região no genoma viral que corresponde ao gene da poliedrina é utilizada para a construção de baculovírus recombinates para de expressão de proteínas heterólogas (O’ Reilly et al., 1992).

Tani et al. (2003) demostraram que baculovírus podem ser usados como potente vetor de entrega gênica em células de mamíferos, pois estes infectam e ao mesmo tempo são incapazes de se replicar, sendo seguros para a manipulação humana. O fato de não se replicarem em células de mamíferos está relacionado com a ausência ou a limitada transcrição dos seus principais genes regulatórios (Liu et al., 2007).

Há trabalhos descritos na literatura que mostram a eficiente expressão de proteína as Cry de B. thuringiensis pelo sistema de expressão baseados em baculovírus e células de inseto, tendo como objetivo de se estudar as proteínas isoladamente e para o aumento da patogenicidade viral em insetos-praga (Martens et al., 1995; Merryweather et al., 1990; Ribeiro et al., 1993, 1998, Aguiar et al., 2006;Lima et al., 2008; Martins et al., 2008; Aguiar et al., 2012, Corrêa et al., 2013). 


\section{Câncer}

Câncer é o nome dado a um grupo formado por mais de cem doenças caracterizadas por uma sequência de eventos anormais na fisiologia da célula, os quais levam a proliferação descontrolada, a capacidade de se expandir para outros tecidos (metástase) e a imortalidade das células (American Cancer Society, 2016; Instituto Nacional de Câncer - INCA, 2016).

O câncer é uma das principais doenças que causa morte no mundo, sendo que em 2013, 14,1 milhões de casos novos de câncer e 8,2 milhões de mortes relacionados ao câncer foram relatados no mundo. Estima-se que no ano de 2030, serão 21,4 milhões de casos novos de câncer e 13,2 milhões de mortes (Oranização Mundial da Saúde OMS). As estimativas para o anos 2016-2017 no Brasil apontam a ocorrência de aproximadamente 596.070 casos novos, incluindo os casos de pele não melanoma, sendo que desses $49 \%(209,960)$ em mulheres e $51 \%(214.350)$ em homens. Os tipos mais incidentes serão os de pele não melanoma, mama, colorretal, colo do útero, e de pulmão para os sexo feminino, já para o sexo masculino, os tipos mais incidentes serão cânceres de pele não melanoma, próstata, pulmão, colorretal e estômago (Tabela 2) (Instituto Nacional de Câncer - INCA).

Tabela 2. Estimativas de novos casos de câncer em Homens e Mulheres em 2016/2017 (INCA 2016)

\begin{tabular}{|c|c|c|c|c|c|c|}
\hline Localização primária & Casos & $\%$ & & Localização primária & Casos & $\%$ \\
\hline \multirow{2}{*}{\multicolumn{7}{|c|}{ 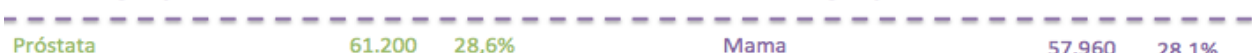 }} \\
\hline & & & & & & \\
\hline Traquéia, Brônquio e Pulmão & 17.330 & $8,1 \%$ & \multirow[t]{2}{*}{$\mathrm{H}$} & Cólon e Reto & 17.620 & $8,6 \%$ \\
\hline Cólon e Reto & 16.660 & $7,8 \%$ & & Colo do útero & 16.340 & $7,9 \%$ \\
\hline Estômago & 12.920 & $6,0 \%$ & & Traquéia, Brônquio e Pulmão & 10.890 & $5,3 \%$ \\
\hline Cavidade Oral & 11.140 & $5,2 \%$ & & Estômago & 7.600 & $3,7 \%$ \\
\hline Esôfago & 7.950 & $3,7 \%$ & & Corpo do útero & 6.950 & $3,4 \%$ \\
\hline Bexiga & 7.200 & $3,4 \%$ & & Ovário & 6.150 & $3,0 \%$ \\
\hline Laringe & 6.360 & $3,0 \%$ & & Glândula Tireóide & 5.870 & $2,9 \%$ \\
\hline Leucemias & 5.540 & $2,6 \%$ & & Linfoma não Hodgkin & 5.030 & $2,4 \%$ \\
\hline Sistema Nervoso Central & 5.440 & $2,5 \%$ & & Sistema Nervoso Central & 4.830 & $2,3 \%$ \\
\hline Linfoma não Hodgkin & 5.210 & $2,4 \%$ & & Leucemias & 4.530 & $2,2 \%$ \\
\hline Glândula Tireóide & 3.000 & $1,4 \%$ & & Cavidade Oral & 4.350 & $2,1 \%$ \\
\hline Todas as Neoplasias sem pele* & 1.460 & $0,7 \%$ & & Esôfago & 2.860 & $1,4 \%$ \\
\hline \multirow[t]{5}{*}{ Todas as Neoplasias } & 1.090 & $0,5 \%$ & & Pele Melanoma & 2.670 & $1,3 \%$ \\
\hline & 214.350 & & & Bexiga & 2.470 & $1,2 \%$ \\
\hline & 295.200 & & & $\begin{array}{l}\text { Linfoma Hodgkin } \\
\text { Laringe }\end{array}$ & $\begin{array}{l}1.010 \\
990\end{array}$ & $0,5 \%$ \\
\hline & & & & Todas as Neoplasias sem pele* & 205.960 & \\
\hline & & & & Todas as Neoplasias & 300.870 & \\
\hline
\end{tabular}


O surgimento do tumor dá-se devido a vários eventos, podendo ser fatores internos como mutações herdadas, dinfunção hormonal, condições imunológicas e mutações geradas em decorrência do metabolismo ou fatores externos como agentes infecciosos, agentes químicos e radiação ionizante (American Cancer Society, 2016).

A escolha da terapia mais adequada e a formulação do prognóstico para um paciente com câncer são feitos com base no conhecimento clínico sobre a extensão da doença e seu comportamento biológico. Em casos de mulheres portadoras do câncer de mama, tipo de câncer que mais acomete mulheres no Brasil, o tratamento é baseado em cirurgia (retirada da mama), quimioterapia, radioterapia e na terapia hormonal, sendo a cirugia o principal tratamento dentre os outros (Purushotham et al., 2012).

A terapia hormonal envolve o uso de inibidores enzimáticos, como inibidores da aromatase, os quais bloqueiam a conversão de hormônios androgênicos em estrógeno, impedindo o crescimento do tumor, e também de moduladores de receptores hormonais, como o tamoxifeno, utilizado para modular o efeito do estrógeno (Li et al., 2009; Puhalla et al., 2012).

A terapia com produtos biotecnológicos tem sido muito utilizada, como por exemplo, o uso de trastuzumab (Herceptin®), anticorpo monoclonal que se liga seletivamente a $H E R-2$, gene responsável pela expressão da proteína HER-2, que tem um papel regulador nas células normais, sendo um proto-oncogene. Uma vez que esse gene é superexpresso, significa que a mulher é portadora do câncer de mama. Sendo assim, o tratamento com trastuzumab é combinado com a terapia hormonal e com o uso de quimioterápuicos, sendo capaz de aumentar a sobrevida dos pacientes, porém essa combinação está relacionada com o aparecimento de toxicidade cardíaca (Maughan et al., 2010; Harbeck, 2011; Pegram \& Liao, 2012).

É de grande importância a descoberta de novas tecnologias para o tratamento de câncer, sendo assim, o estudo de Parasporinas pode ser algo de extrema relevância, uma 
vez que essas toxinas apresentam certa toxicidade a células tumorais, podendo ser usada, futuramente como uma ferramenta biotecnológica.

\section{Objetivo geral}

Este trabalho teve como objetivo, a expressão da protéina PS2 de $B$. thuringiensis em células de inseto e a análise de sua atividade tóxica in vitro.

\subsection{Objetivos específicos}

- Construção de um baculovirus recombinante contendo o gene ps 2 de $B$. thuringiensis;

- Análise da expressão da protéina PS2 em células de inseto infectadas pelo vírus recombinante;

- Purificação da proteína PS2 recombinante e análise de sua atividade citotóxica em células tumorais e células de inseto;

- Análise morfológica dos cristais da protéina recombinate

- Análise morfológica das células tratadas com a protéina recombinante.

\section{MATERIAIS E MÉTODOS}

\subsection{Células e Vírus}

Neste trabalho foram utilizados os vírus Autographa californica multiple nucleopolyhedrovirus (AcMNPV), o vírus recombinante vAc/occ-, que não possui o gene da poliedrina, não produzindo poliedros (Ardisson-Araújo et al., 2013), e o vírus recombinante chamado de vAcPS2His construído neste trabalho. Os vírus foram propagados em células BTI-Tn5B1-4 derivadas de Trichoplusia ni (Granados et al., 1994), células IPLB-Sf21-AE (Sf21) e Sf9, derivadas de Spodoptera frugiperda (Vaughn et. al., 1977), mantidas em meio TC-100 (Gibco-BRL) suplementado com 
$10 \%$ de soro fetal bovino mantidas a $27^{\circ} \mathrm{C}$. Células de Escherichia coli DH5 $\alpha$ (Invitrogen) foram utilizadas como hospederias para a maioria dos plasmídeos utilizados no presente trabalho. No entanto, em experimentos envolvendo Bac-to-Bac "Baculovírus Expression System" (Invitrogen), foram utilizadas células E. coli DH10Bac que possuem o Bacmídeo, o genoma completo de baculovírus em forma de um grande plasmídeo, e um plasmídeo chamado Helper, que codificam enzimas chamadas transposases, capazes de reconhecer sítios de transposição do vetor de transferência e o Bacmídeo, para que o gene de interesse seja transposto do vetor de transferência para o bacmídeo (Invitrogen).

Para avaliação da atividade antitumoral das proteína PS2 de B. thuringiensis, foram usadas linhagens celulares de câncer de mama MCF-7 e MDA-MB-231, obtidas do Banco de Células do Rio de Janeiro (BCRJ - Associação Técnico Científica Paul Ehrlich Inmetro). Como controle foi usada a linhagem não tumoral de fibroblasto de polpa dentária humana saudável, cedida pelo Departamento de Genética e Morfologia do Instituto de Biologia da Universidade de Brasília - UnB.

As células (MCF-7 e Fibroblasto) foram cultivadas em meio Dulbecco's Modified Eagle's Medium (DMEN) (Gibco - Life Technologies - Carlsbad, CA, EUA), mantidas a $37^{\circ} \mathrm{C}$ com $5 \%$ de $\mathrm{CO}_{2}$, diferentemente das células MDA-MB-231 que foram cultivadas em meio Leibovitz L15 (Sigma - Aldrich - St. Louis, MO, EUA) a $37^{\circ} \mathrm{C}$ na ausência de $\mathrm{CO}_{2}$. Ambos os meios foram suplementados com $10 \%$ de soro fetal bovino inativado (SFB) (Gibco - Life Technologies - Carlsbad, CA, EUA) e $25 \mu \mathrm{g} / \mathrm{mL}$ de gentamicina.

\subsection{Montagem do gene PS2 e clonagem.}

O gene ps2 foi sintetizado pela empresa IDT (Integrate DNA Technologies) em três fragmentos de 370 pares de bases (pb) a partir de uma sequência de 
nucleotídeos presente no banco de dados (GenBank - número de acesso: AB099515 https://www.ncbi.nlm.nih.gov/nucleotide/32469225?report=genbank\&log $\$=$ nuclalign $\&$ blast_rank=1\&RID=NCA2MEDK01R) isolado da bactéria de $B$. thuringiensis serovar Dakota (Ito, A. et al., 2004).

A montagem do gene foi feita por meio da reação em cadeia da polimerase (PCR) por "overlap" (sobreposição) (Figura 9) dos três fragmentos sintetizados, gerando o gene ps2 inteiro, como é mostrado no esquema da Figura 10. Os fragmentos foram amplificados por meio da PCR, segundo as instruções do fabricante da enzima LongAmp ${ }^{\circledR}$ Taq DNA Polymerase (New England BioLabs ${ }^{\circledR}{ }_{\text {nc. }}$ ), com o uso de oligonucleotídeos Ps2Aa-Frag1 F (5'-ggatccATGcatcaccatcaccatc-3'), Ps2Aa-Frag2 R (5'-gctcttaactgaatagttcttctac-3') e Ps2Aa- Frag3 R (5'-aagcttctaattcccccattttggg-3') que foram desenhados a partir da sequencia do gene $p s 2$ já publicada. Sítios de restrição para a enzima BamHI e HindIII e uma sequência de seis histidinas foram adicionadas (letras em vermelho) à sequencia, como mostrado na Figura 9. O programa de PCR utilizado para a reação de montagem do gene foi de $94{ }^{\circ} \mathrm{C} / 1 \mathrm{~min}, 30$ ciclos de 94 ${ }^{\circ} \mathrm{C} / 1 \mathrm{~min}, 51{ }^{\circ} \mathrm{C} / 40 \mathrm{seg}$, e $65^{\circ} \mathrm{C} / 40 \mathrm{seg}$ e uma extensão final de $65^{\circ} \mathrm{C} / 7 \mathrm{~min}$. O resultado da PCR foi analisado por eletroforese em gel de agarose $0.8 \%$ de acordo com o protocolo descrito em Sambrook, et. al., (1989).

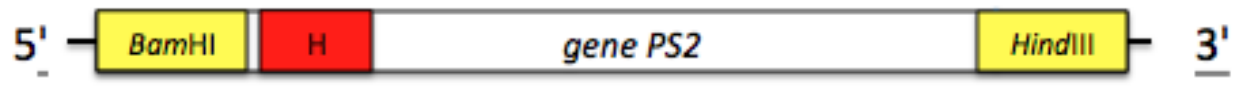

Figura 9. Esquema representativo do gene ps2. Em amarelo sítios de restrição BamHI e HindIII, respectivamente; em vermelho, a sequência de seis histidinas, em branco, a sequência de nucleotídeos referente ao gene. 


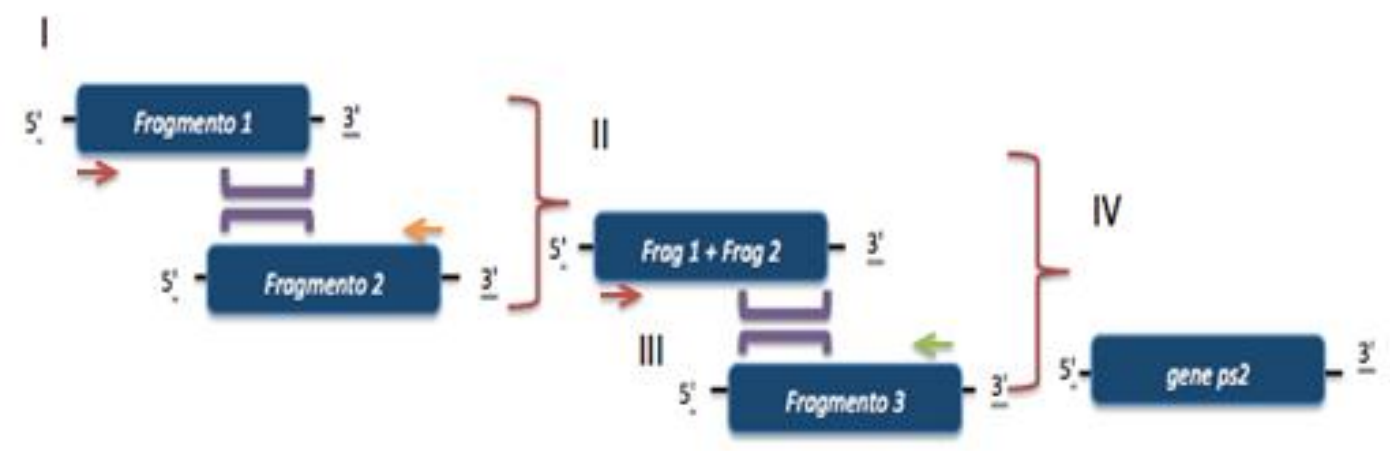

Figura 10. Esquema representativo da construção do gene ps 2 por overlap. Primeira reação de amplificação, onde o fragmento 1 e o fragmento 2 apresentem região de sobreposição (em roxo). (II) Fragmento gerado (junção dos fragmentos 1 e 2). (III) Segunda reação de amplificação, onde c fragmento $1+2$ apresenta região de sobreposição (em roxo) com o fragmento 3. (IV) gene ps2 após junção dos três fragmentos. Setas coloridas indicam os oligonucleotídeos. Em vernelho oligonucleotídec forward fragmento 1; em laranja oligonucleotídeo reverse fragmento 2 e em verde, oligonucleotídeo reverse fragmento 3.

0 fragmento de DNA com o tamanho esperado para o gene ps2 (1.100 pb), foi eluído do gel, usando o Kit GFX DNA and Gel Band Purification (GE) seguindo as instruções do fabricante. Este, após purificação foi clonado no vetor pGem-T ${ }^{\circledR}$ easy - Promega (Figura 11), de acordo com o protocolo de instruções do fabricante, gerando o plasmídeo pGemPs2Aa6xHis. A confirmação do plasmídeo foi feita por digestão com a enzima de restrição EcoRI onde foi liberado um fragmento de 1.100 $\mathrm{pb}$ referente ao gene ps2 e um fragmento de $3.000 \mathrm{pb}$ referente ao vetor $\mathrm{pGem}-\mathrm{T}^{\circledR}$ easy, e também por sequenciamento dos cassetes de expressão (Macrogen, Coréia do Sul). 


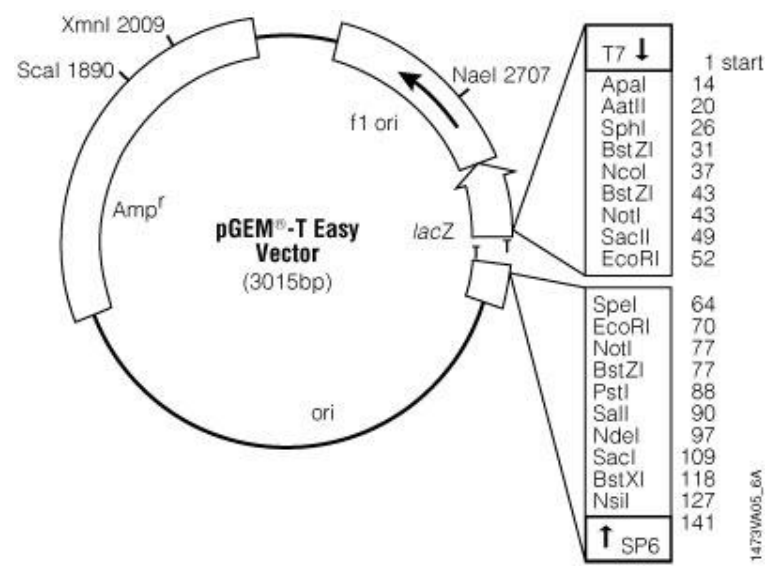

Figura 11. Esquema do vetor pGem - T Easy (Promega). O sítio de multiclonagem com a localização de cada enzima de restrição, o gene $l a c-Z$ e o gene de resistência ao antibiótico ampicilina são mostrados na figura. Além disso, a posição de anelmaneto dos oligonucleotídeos SP6 e T7 são também mostrados (Foto retirada do Manual Técnico - pGEM $^{\circledR}$-T and pGEM ${ }^{\circledR}$-T Easy vector Systems.

\subsection{Clonagem do gene $p s 2$ no vetor de transferência}

O plasmídeo contendo o gene ps2 (pGemPs26xHis) foi digerido com enzimas de restrição BamHI e HindIII (Promega) de acordo com o protocolo de instruções do fabricante. Da mesma forma, o vetor $\mathrm{pFastBac}^{\mathrm{TM}}$ (Invitrogen) (Figura 11) foi digerido com as mesmas enzimas. Ambas as reações de digestão foram mantidas a $37{ }^{\circ} \mathrm{C}$ por $16 \mathrm{~h}$ ('overnight').

$\mathrm{O}$ vetor de transferência pFastBac1 ${ }^{\mathrm{TM}}$ (Figura 12) é usado para clonagem de genes heterólogos que serão introduzidos no genoma do baculovírus Autographa californica multiple nucleopolyhedrovirus (AcMNPV). Este foi usado para reação de ligação com o fragmento digerido referente ao gene $p s 2$ utilizando a enzima T4 DNA ligase (Promega) de acordo com o protocolo de instruções do fabricante. 


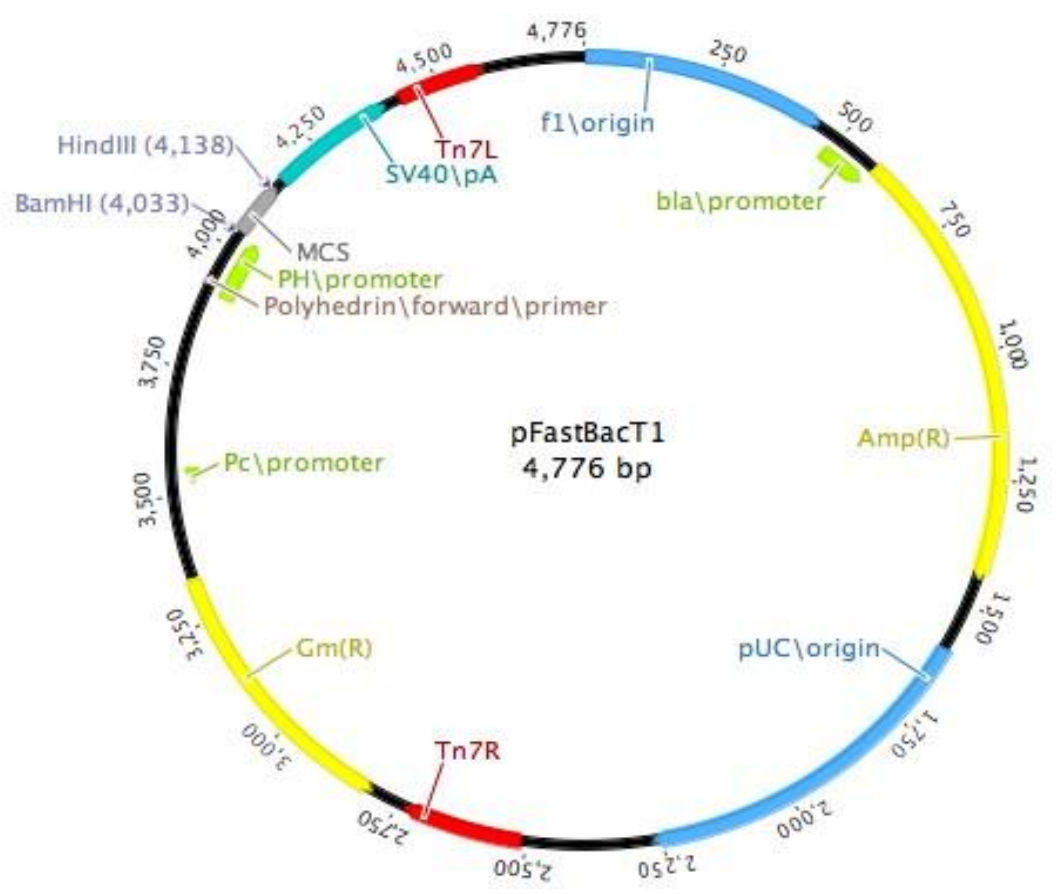

Figura 12. Esquema do vetor pFastBac1 (Invitrogen). Os sítios reconhecidos pelas enzimas de restrição BamHI e HindIII; o Promotor da Poliedrina $\left(\mathrm{Pp}_{\mathrm{PH}}\right)$, o qual permite um alto nível de expressão da proteína recombinante em células de inseto; SV40 - Sinal de poliadenilação, que permite uma eficiente terminação da transcrição e poliadenilação do RNA mensageiro (mRNA); os sítios de Tn7L e Tn7R, que são elementos que permitem a transposição sítio-específica do gene de interesse para o genoma do baculovírus; os genes, ampicilina, para selecionar o plasmídeo em E. coli, e gentamicina, que permite a seleção do bacmídeo recombinante em $\mathrm{DH} 10 \mathrm{Bac}^{\mathrm{TM}}$ E. coli; e pUClorigin, que permite o alto nível de cópias em E. coli.

Após a ligação, foi realizada uma transformação pelo método de choque térmico (Sambrook et al., 1989), onde foram utilizadas células E. coli DH5a quimiocompetentes comerciais (Invitrogen). Os clones resultantes da transformação foram selecionados por resistência aos antibióticos ampicilina $(50 \mu \mathrm{g} / \mathrm{mL})$ e gentamicina $(7$ $\mu \mathrm{g} / \mathrm{mL}$ ). Colônias resultantes da transformação foram coletadas e crescidas em $1 \mathrm{~mL}$ de meio LB líquido (Luria-Bertani broth - Gibco® LB Broth - ThermoFisher Scientific; $10 \mathrm{~g}$ de peptona; $5 \mathrm{~g}$ de extrato de levedura; $5 \mathrm{~g}$ de cloreto de sódio) com os respectivos antibióticos a $37^{\circ} \mathrm{C}$ por $16 \mathrm{~h}$. Posteriormente, foi feita uma extração plasmidial por lise alcalina (Sambrook et al., 1989), onde $900 \mu 1$ do pré-inóculo foi centrifugado por $1 \mathrm{~min}$ a $14.000 \mathrm{rpm}$ (Microcentrífuga 5418 - Eppendorf). O sobrenadante foi aspirado e o sedimento (células bacterianas) resultante da centrifugação foi ressuspendido em $100 \mu \mathrm{l}$ de solução I (50 mM glicose, 25 mM Tris-HCL pH 8, 10 mM EDTA pH 8) seguido de 
acréscimo de $200 \mu \mathrm{l}$ de solução II (NaOH 0,2 M, SDS 2\%) e incubado 5 min à temperatura ambiente, acrescidos de $150 \mu 1$ de solução III (acetato de potássio $5 \mathrm{M}$, ácido acético glacial, $\mathrm{H}_{2} \mathrm{O}$ ) e incubado no gelo por 20 min. Após a incubação, a amostra foi centrifugada por $10 \mathrm{~min}$ a $14.000 \mathrm{rpm}$ (Centrífuga 5418 - Eppendorf) e o sobrenadante foi retirado e transferido para um tubo novo onde foi acrescido $220 \mu \mathrm{de}$ clorofórmio, seguido de homogeneização e centrifugação por 10 min a $14.000 \mathrm{rpm}$ (Microcentrífuga 5418 - Eppendorf). Após a centrifugação, resultaram duas fases, uma orgânica e uma aquosa. A fase aquosa (fase superior) foi coletada e transferida para um novo tubo onde foram acrescidos $350 \mu \mathrm{l}(0,6 \%)$ de álcool isopropílico, seguido de centrifugação por 10 min a $14.000 \mathrm{rpm}$ (Microcentrífuga - 5418 - Eppendorf). O sobrenadante foi retirado e ao precipitado foram adicionados $500 \mu \mathrm{l}$ de álcool etílico $70 \%$, onde a amostra foi centrifugada pela última vez por 10 min a $14.000 \mathrm{rpm}$. Ao final, o sobrenadante foi descartado e o precipitado que corresponde ao DNA, foi ressuspendido em $20 \mu 1$ de água destilada.

Como forma de confirmação da clonagem, foi realizada uma reação de digestão com as enzimas de restrição BamHI e HindIII (Promega) onde foram utilizados para essa reação $7 \mu 1$ de DNA plasmidial, $1 \mu 1$ de tampão 10X (Promega), $1 \mu 1$ de BSA 10X (albumina bovina sérica) (Promega), 1U de enzima BamHI (Promega), 1U de enzima HindIII (Promega), e água "milli-Q“ para um volume final de $10 \mu 1$. O resultado da digestão foi analisado por eletroforese em gel de agarose $0.8 \%$ como descrito acima. Dois plasmídeos confirmados foram sequenciados. (Macrogen, Coréia do Sul).

\subsection{Obtenção do baculovírus recombinante}

O plasmídeo (pFastPs26xHis), obtido no passo anterior, foi usado para construção do baculovírus recombinante, onde este foi transformado em células DH10Bac ${ }^{\mathrm{TM}}$ E. coli, as quais possuem o genoma do baculovírus AcMNPV na forma de 
um grande plasmídeo (bacmídeo) bMON14271 (136 kb), que possui o gene de resistência a kanamicina, um segmento de DNA que codifica o peptídeo LacZ $\alpha$ e um sítio de transposição bacteriana Tn7 (mini-attTn7). Bacmídeos recombinantes são gerados por transposição do fragmetno de DNA flanqueado pelas regiões Tn7L e Tn7R do plasmídeo doador $\mathrm{pFastBac}^{\mathrm{TM}}$ para o sítio mini-att $\mathrm{Tn} 7$ presente no bacmídeo. A transposição que ocorre com o auxílio do plasmídeo Helper, pMON7124 (13.2 kb), que também está presente na célula $\mathrm{DH} 10 \mathrm{Bac}^{\mathrm{TM}}$ E. coli. O plasmídeo helper codifica transposases que promovem a transposição do fragmento flanqueado pelas regiões Tn7L e Tn7R , e possui resistência a tetraciclina (Bac-to-Bac ${ }^{\circledR}$ - Invitrogen). Células DH10Bac ${ }^{\mathrm{TM}}$ quimiocompetentes foram então, trasnsformadas com o plasmídeo pFastBacPs26xHis (Sambrook et al., 1989) e plaqueadas em meio de cultura LB (Luria Broth - Ultrapure Affymetrix ${ }^{\circledR}$ - peptona caseína $10 \mathrm{mg} / \mathrm{mL}$; extrato de levedura 5 $\mathrm{mg} / \mathrm{L}$; cloreto de sódio $10 \mathrm{mg} / \mathrm{ml}$ e Ágar bacteriológico $12 \mathrm{mg} / \mathrm{l}$ ) contendo antibióticos como, tetraciclina $(10 \mu \mathrm{g} / \mathrm{ml})$, gentamicina $(7 \mu \mathrm{g} / \mathrm{ml})$ e kanamicina $(50 \mu \mathrm{g} / \mathrm{ml})$ e também reagentes IPTG $(40 \mu \mathrm{g} / \mathrm{ml})$ E X-Gal $(100 \mu \mathrm{g} / \mathrm{ml})$, todos usados como forma de seleção dos clones e mantidas a $37^{\circ} \mathrm{C}$ por 48 h. Colônias brancas e uma colônia azul (controle negativo) resultantes da transformação foram coletadas e crescidas em meio LB líquido (Luria Broth - Ultrapure Affymetrix ${ }^{\circledR}$ - peptona caseína $10 \mathrm{mg} / \mathrm{mL}$; extrato de levedura $5 \mathrm{mg} / \mathrm{L}$; cloreto de sódio $10 \mathrm{mg} / \mathrm{ml}$ ) com os mesmos antibióticos utilizados anteriormente a $37^{\circ} \mathrm{C}$ por $16 \mathrm{~h}$. Os inóculos crescidos overnight foram submetidos a extração de DNA plasmidial por lise alcalina como descrito no manual Bac-to-Bac® (Invitrogen).

Como forma de confirmação do bacmídeo, foi realizada uma reação de PCR com oligonucleotídeos M13F (5'-cccagtcacgacgttgtaaaacg-3') e M13R (5'agcggataacaatttcacacagg-3') que amplificam todo o cassete de transposição. O programa de PCR utilizado para a reação de confirmação por PCR foi de $94{ }^{\circ} \mathrm{C} / 3 \mathrm{~min}$, 
30 ciclos de $94{ }^{\circ} \mathrm{C} / 45 \mathrm{seg}, 55^{\circ} \mathrm{C} / 1 \mathrm{~min}, 72{ }^{\circ} \mathrm{C} / 3 \mathrm{~min}$ e $30 \mathrm{seg}$, e extensão final de 72 ${ }^{\circ} \mathrm{C} / 7$ min. O resultado da PCR foi analisado por eletroforese em gel de agarose $0.8 \%$ de acordo com o protocolo descrito em Sambrook et. al., (1989). Foram escolhidos três clones positivos. Estes foram crescidos em $20 \mathrm{~mL}$ de meio LB líquido com antibióticos tetraciclina $(10 \mu \mathrm{g} / \mathrm{ml})$, gentamicina $(7 \mu \mathrm{g} / \mathrm{ml})$ e kanamicina $(50 \mu \mathrm{g} / \mathrm{ml})$ por $16 \mathrm{~h}$ sob agitação em shaker (Incubated/Refrigerated Stackable orbital shaker - Thermo Scientific) a $37{ }^{\circ} \mathrm{C}$. Foram feitas duas alíquotas de cada clone em glicerol $80 \%$ e em seguida, extração de DNA por lise alcalina foi realizada de acordo com o manual Bacto-Bac® (Invitrogen).

\subsubsection{Transfecção em células de inseto e amplificação do vírus.}

Após confirmação do bacmídeo recombinante, $1 \mu \mathrm{g}$ do DNA plasmidial foi transfectado em células BTI-Tn5B1-4. Foram adicionados $500 \mu \mathrm{L}$ de meio de cultura TC-100 sem soro, $1 \mu \mathrm{g}$ de DNA do bacmídeo e $10 \mu \mathrm{L}$ de lipossomo (Cellfectin®, Invitrogen) em uma placa de $35 \mathrm{~mm}$ (TPP). A placa foi incubada por $30 \mathrm{~min}$ à temperatura ambiente. $\mathrm{O}$ meio de cultura da placa de célula preparada previamente foi retirado e a mistura de DNA com lipossomo foi adicionada as células deixando-as por 4h agitando à temperatura ambiente. Após o tempo de incubação, o meio de cultura foi retirado das células e 1,5 ml de meio de cultura TC-100 com $10 \%$ de soro fetal bovino foi adicionado as células e estas foram incubadas a $27^{\circ} \mathrm{C}$ por sete dias.

Após 7 dias de transfecção, as células foram visualizadas em microscópio de luz para análise de sinais de infecção viral, como hipertrofia nuclear e mudança da forma celular. O sobrenadante das células transfectadas foi inoculado em placas contendo $5 \mathrm{x}$ $10^{6}$ células Sf21 (O’Reilly et al., 1992) para amplificação viral. Sete dias após a infecção, o sobrenadante das células infectadas foi coletado, titulado pelo método de 
diluição seriada em placas de 96 poços segundo O'Reilly et al. (1992) e armazenado a $4^{\circ} \mathrm{C}$.
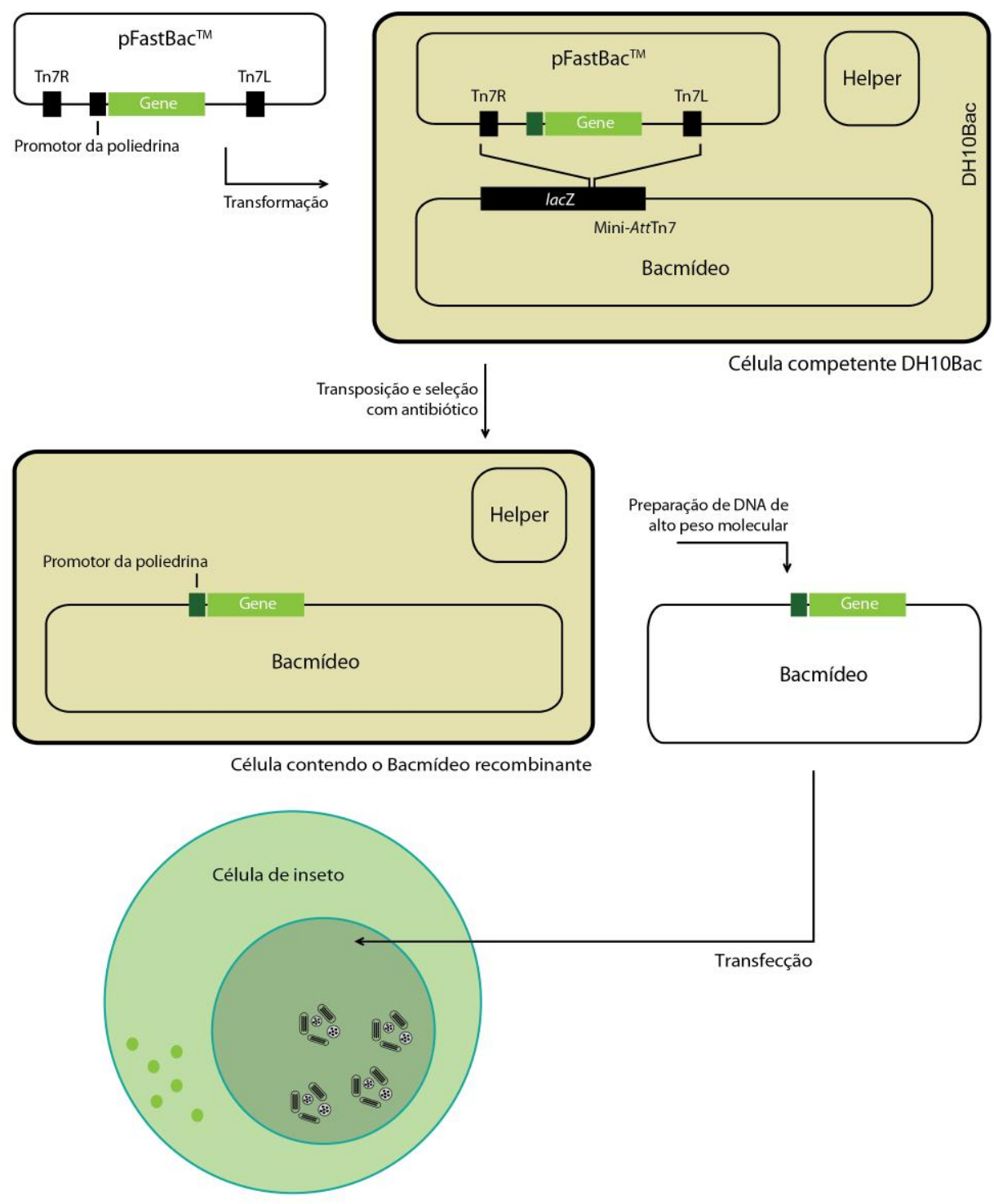

Expressão de Proteína heteróloga

Figura 13. Esquema ilustrativo da construção de baculovírus recombinantes pelo método de transposição sítio-dirigida (adaptado do manual Bac-to-Bac® Baculovirus Expression System, Invitrogen). $\mathrm{O}$ vetor de transferência contendo o gene de interesse é transformado em células competentes, as quais possuem o bacmídeo, genoma do baculovírus. O plasmídeo helper codifica transposases que catalisam a transposição do gene heterólogo para o bacmídeo. O gene lac Z inserido no lócus da poliedrina tem como função ser uma marcador gênico seletivo para clones recombinantes. DNA recombinante do bacmídeo é isolado e utilizado para transfectar células de inseto para produção de vírus recombinantes. 


\subsection{Análise da expressão da proteína recombinante}

A confirmação da expressão da proteína recombinante foi feita por análise do extrato de células infectadas pelo vírus recombinante vAcPS2His em eletroforese em gel de poliacrilamida (SDS - PAGE) 12\% (Laemmeli, 1970) utilizando o aparato Mini Protean II (BioRad) e por Western blot, utilizando o anti-soro monoclonal anti-His (GE).

Dois géis foram feitos, usando o aparato Mini Trans - Blot cells de acordo com o protocolo de instruções do fabricante (Bio-Rad), onde um gel foi corado e fixado em solução de $40 \%$ de metanol e $10 \%$ de ácido acético, $0,1 \%$ de corante de Azul brilhante de Comassie R-250 por 16h. O outro gel foi utilizado para transferência da proteína em membrana de nitrocelulose (Gibco BRL - Life Technologies) para o experimento de imunomarcação de proteínas (Western blot).

O procedimento de transferência foi realizado com o auxílio do aparato de transferência Trans-Blot SD Semi-Dry Transfer Cell (Bio-Rad) de acordo com as instruções do fabricante. Após a corrida das proteínas em eletroforese de gel de poliacrilamida, o gel foi incubado em tampão de transferência Bjerrum and SchaferNielsen (48mM de Tris, $39 \mathrm{mM}$ de glicina, $20 \%$ de metanol, $\mathrm{pH} 9.2$ ) por $15 \mathrm{~min}$. A membrana foi imersa no mesmo tampão de transferência por $5 \mathrm{~s}$, sem entrar em contato com o gel. Foi montado um sanduíche (dois papéis de filtro, membrana de nitrocelulose, gel e dois papéis de filtro) e a transferência foi realizada com o protocolo Mixed Proteins conforme instruções do fabricante que constam no aparelho de transferência. Após a transferência, a membrana foi bloqueada com solução de PBS 1X e 5\% de leite em pó desnatado por 1h, à temperatura ambiente sob agitação. Seguido o procedimento de bloqueio, a membrana foi lavada 3 vezes com solução PBS Tween $(0.05 \%)$ por 5 
min para que toda a solução de bloqueio fosse retirada e não atrapalhe no reconhecimento do anticorpo no passo seguinte. A membrana foi incubada com solução de PBS 1X, albumina bovina sérica (BSA) 0,5\% e anticorpo primário policlonal antiHis (GE Healthcare) produzido em camundongo na diluição 1:10000 por 1h, à temperatura ambiente sob agitação. Após a incubação com o anticorpo primário, a membrana foi lavada 3 vezes com solução PBS Tween $(0,05 \%)$ por 5 min e foi incubada com PBS 1X, BSA 0,5\% e o anticorpo secundário, anti-IgG produzido em camundongo, conjugado com a enzima fosfatase alcalina (Sigma) na diluição de 1:8000 por 1h, à temperatura ambiente sob agitação. Em seguida, foi retirada a solução de anticorpo secundário e a membrana foi lavado 3 vezes com PBS Tween $(0,05 \%)$ por 5 min. Finalmente, foi adicionada a solução reveladora, NBT/BCIP (Invitrogen), que serve como substrato para a enzima fosfatase alcalina. Uma vez que o substrato é metabolizado pela enzima fosfatase alcalina que está ligada ao anticorpo secundário, que se ligou ao anticorpo primário, que está ligado na proteína de interesse, esta aparece com uma marcação roxa, confirmando sua expressão.

\subsection{Cinética de expressão e visualização de cristais em célula de inseto.}

Em uma placa de seis poços (TPP) foram plaqueadas $10^{6}$ células Sf9 em cada poço, e 10 pfu/célula do vírus recombinante vAcPS26xHis foi inoculado em cada poço. Em diferentes tempos (24, 48, 72 e 96 h após infecção, p.i.), as células foram fotografadas com o auxílio do microscópio de luz invertido (ZEISS Axiovert 100) para mostrar a presença de cristais formados e coletadas para analisar a cinética de expressão da proteína recombinante. As células coletadas foram submetidas a centrifugação a 7.000 r.p.m (Sorvall Legend XTR Centrifugue - Thermo Scientific) por 10 min e o precipitado de células foi lavado 3 vezes com PBS 1X nas mesmas condições de centrifugação. O pellet de células foi ressuspendido em $300 \mu \mathrm{L}$ de PBS 1 X e este foi 
armazenado com inibidor de protease (Sigma) no freezer a menos 80 graus. Após a coleta de todos os tempos, foi feita a análise de cinética de expressão em eletroforese em gel de poliacrilamida (SDS - PAGE) 12\% (Laemmeli, 1970) e por Western blot como descrito no item 5.4.

\subsection{Caracterização morfológica de cristais de PS2 por microscopia eletrônica de varredura (MEV).}

Células Sf9 foram infectadas com MOI 1 (Multiplicidade de infecção) com o vírus recombinante vAcPS2His e coletadas a 96 h p.i. e lavadas como descrito no item 4.6. Após lavagem com PBS, as células contendo os cristais foram lavados (3x) com 0,5\% de SDS (dodecil sulfato de sódio) e centrifugadas a $5.000 \mathrm{rpm}$ por $5 \mathrm{~min}$ (Microcentrífuga 5418 - Eppendorf), seguidas de 2 lavagens com 0,5 $\mathrm{M}$ de $\mathrm{NaCl}$ (Cloreto de sódio), seguidas de centrifugação como descrito acima (Miller \& Dawes, 1978). Foi feita uma lâmina para observar a qualidade dos cristais e a presença ou não de células por microscopia de luz (ZEISS Axiovert 100). Confirmada a presença de cristais e a lise completa das células por microscopia de luz, os cristais foram ressuspendidos em $20 \mu \mathrm{L}$ de água Milli-Q autoclavada e todo o material foi depositado sobre suportes metálicos (stubs), previamente preparados com fita carbono para a análise em microscopia eletrônica de varredura. As amostras foram metalizadas com ouro pelo período de $90 \mathrm{~s}$, utilizando-se metalizador Leica modelo EM SCD500 e observadas em Microscópio Eletrônico de Varredura (MEV) Zeiss modelo DSM 962.

\subsection{Purificação, solubilização, ativação e quantificação da toxina parasporina -2 .}

Células Sf9 foram infectadas (MOI 1) com o vírus recombinante vAcPS2His a fim de expressar a protoxina PS2 (pró-ps2) e a 72 h p.i., as células foram coletadas e 
lavadas 1 vez com PBS $1 \mathrm{X}$ e ressuspendidas em solução salina $(0,5 \mathrm{M}$ de $\mathrm{NaCl}$ e $0,1 \mathrm{M}$ de EDTA). Após lavagem do extrato celular, este foi submetido a purificação do cristais, com algumas modificações, pelo método de purificação de cristais com o solvente orgânico Hexano (Rahbani et al., 2014). O extrato celular foi então lavado 2 vezes com $40 \mathrm{~mL}$ solução salina e 2 vezes com solução salina e detergente Triton $0,1 \%$, resultando em $40 \mathrm{~mL}$ de volume final, para lisar as células. Ambas as lavagens foram feitas intercalando centrifugação a 6.000 r.p.m, por 10 min a $4^{\circ} \mathrm{C}$ (Sorvall Legend XTR Centrifugue - Thermo Scientific). Em seguida ao passo de lise celular, foram feitas 2 lavagens com solução salina e 5\% de solvente hexano (volume final $40 \mathrm{~mL}$ ), com centrifugação a 6.000 r.p.m, por 10 min a $4^{\circ} \mathrm{C}$ (Sorvall Legend XTR Centrifugue Thermo Scientific). O sobrenadante foi descartado e outras duas lavagens com solução salina e $10 \%$ de solvente hexano (volume final $40 \mathrm{~mL}$ ) foram feitas, seguidas de centrifugação a 6.000 r.p.m, por 10 min a $4^{\circ} \mathrm{C}$ (Sorvall Legend XTR Centrifugue Thermo Scientific). Após as lavagens de purificação com Hexano, o sedimento foi lavado 2 vezes com água destilada gelada para retirar o solvente orgânico, seguido de centrifugação nas mesmas condições anteriores. Foi feita uma lâmina para visualizar a qualidade dos cristais e da purificação. Em todos os passos a amostra foi manipulada no gelo para não degradar a proteína. Uma alíquota de proteína purificada por Hexano foi misturada a 2X SDS gel - loading buffer ( $100 \mathrm{mM}$ de Tris - $\mathrm{HCl}$ pH 6.8; $200 \mathrm{mM}$ de 2- $\beta$-mercaptoetanol; $4 \%$ de SDS; 0,2\% de azul de bromofenol; $20 \%$ de glicerol e água destilada para completar) (Sambrook et al., 1989) para posterior análise de pureza por SDS-PAGE e Western blot, como no item 4.5.

Seguido o processo de purificação dos cristais de PS2, estes foram submetidos ao processo de solubilização. Foi adicionado a protoxina PS2 em uma solução de 50 $\mathrm{mM}$ de $\mathrm{NaCO}_{3}$ (carbonato de sódio) $\mathrm{pH}$ 10.5, $10 \mathrm{mM}$ de DTT (dithiothreitol ThermoFisher - Scientific) por 1h, sob agitação em shaker (Incubated/Refrigerated 
Stackable orbital shaker - Thermo Scientific) a $37{ }^{\circ} \mathrm{C}$. Em seguida o pH foi neutralizado com solução de $100 \mathrm{mM}$ de Tris- $\mathrm{HCl}$ pH 9.0 e a parte insolúvel foi sedimentada por centrifugação a 7.000 r.p.m por 10 min (Microcentrífuga 5418 Eppendorf) (Brasseur et al., 2015). O Sobrenadante correspondente aos cristais solubilizados foi transferido para um novo tubo e o precipitado foi ressuspendido em água destilada. Uma alíquota da parte solubilizada (protoxina) e não solubilizada foi analisadas em, por SDS-PAGE e Western blot, como no item 4.5.

A protoxina PS2 solubilizada foi submetida a diálise em tampão PBS 0,5X gelado, pH 7.4 em membrana de diálise (Dialysis tubing celulose membrane - Sigma Aldrich) por $16 \mathrm{~h}$ na câmara fria a $4{ }^{\circ} \mathrm{C}$. Após o procedimento de diálise, a protoxina PS2 foi ativada com proteinase $\mathrm{K}(10 \mu \mathrm{g} / \mathrm{ml})$ a $37{ }^{\circ} \mathrm{C}$ por $1 \mathrm{~h}$. A reação foi interrompida com 1mM de PMSF (Phenylmethylsulfonyl Fluoride - Sigma). Uma alíquota da proteína ativa foi adicionada ao tampão2X SDS gel - loading buffer (Sambrook et al., 1989), como descrito anteriormente para posteriormente serem analisadas por SDSPAGE e Western blot, como no item 4.5.

A quantificação da proteína foi feita pelo kit BCA, seguindo as instruções do fabricante (Bicinchoninic Acid Protein Assay Kit - Sigma Aldrich) .

\subsection{Ensaio de citotoxicidade em células de inseto}

Através do ensaio de brometo de 3-(4,5-dimetil-2-tiazoil)-2,5-difeniltetrazólio (MTT) é possível medir a proliferação celular e citotoxicidade (Mosman, 1983). A redução do sal de MTT é um método colorimétrico, onde este, quando metabolizado pela atividade celular ligada a $\left(\mathrm{NADH}^{+}\right.$e $\left.\mathrm{NADPH}^{+}\right)$de células viáveis, resulta na formação de cristais de formazan, de cor azul, que são posteriormente solubilizados, 
podendo ser quantificados através da técnica de spectrofotometria. A quantidade de cristais de formazan é diretamente proporcional ao número de células viáveis.

Foi feito um ensaio com 5 tempos $(24,48,72$ e 96h) diferentes de infecção para avaliar o tempo de das células quando infectadas com o vírus recombinante vAcPs2His e o vírus controle oclusão negativa vAc/occ-. Em uma placa de 96 poços foram plaqueadas $5 \times 10^{4}$ células SF9/200 $\mu$ l (4 placas, uma para cada tempo diferentes de tratamento), totalizando nove poços para cada vírus e nove poços para o controle, células sem tratamento. Após $4 \mathrm{~h}$ de adesão das células na placa, as mesmas foram infectadas com os respectivos vírus titulados com uma MOI 5, garantindo que todas as células sejam infectadas. As células foram deixadas sob agitação a temperatura ambiente por $1 \mathrm{~h}$ para promover infecção. Após $1 \mathrm{~h}$, o meio de todas as células foi retirado. As células foram lavadas 1 vez com $100 \mu 1$ de meio TC-100, sem soro fetal bovino. O meio foi retirado e $200 \mu \mathrm{l}$ de meio TC -100 com $10 \%$ de soro fetal bovino foi adicionado. A viabilidade celular foi medida através do ensaio de brometo de 3-(4,5dimetil-2-tiazoil)-2,5-difeniltetrazólio (MTT) .

Após cada período de tratamento, o meio foi retirado e foi adicionado $150 \mu \mathrm{l}$ de MTT $\left(0,5 \mathrm{mg} / \mathrm{mL}\right.$ em meio de cultura), incubando as células tratadas em estufa a $28{ }^{\circ} \mathrm{C}$. Em seguida, a solução de MTT foi desprezada e $200 \mu$ l de dimetilsulfóxido (DMSO) foram adicionados em cada poço para solubilização dos cristais de formazan. As placas foram avaliadas com o auxílio do espectrofotômetro Spectramax M5 (Molecular Devices - USA). A absorbância do corante foi medida a $595 \mathrm{~nm}$ no espectrofotômetro e a taxa de sobrevivência foi calculada. Os experimentos foram realizados em triplicata biológica e em triplicata experimental. A porcentagem de células viáveis foi determinada comparando a densidade celular das células tratadas com a densidade de células não tratadas (controle), através da fórmula: Viabilidade celular $(\%)=(\mathrm{OD} 595$ de células tratadas/OD 595 células não tratadas) X 100 . 


\subsection{Ensaio de viabilidade celular em célula tumoral de mamífero}

A viabilidade de células de câncer de mama humano (MCF-7 e MDA-MB231), ) e célula não tumoral humana (fibroblasto) tratadas com a toxina PS2 também foram analisadas com a técnica de MTT. Foram plaqueadas 3 x $10^{3}$ células MCF-7, MDA-MB-231 ou fibroblastos por poço, em placas de 96 poços e incubadas overnight a $37{ }^{\circ}$ C. Após adesão, as células foram tratadas em diferentes concentrações com a proteína PS2. Após o tempo de tratamento (24h) as células foram submetidas a à incubação com MTT como descrito no item 4.9.

\subsection{Análises estatísticas}

As análises estatísticas para o teste de viabilidade celular em células de inseto e células tumorais foram feitas através do Teste t-student, utilizando o programa GraphPad Prism (GraphPad Software, San Diego, CA, USA). Foram considerados significativos os valores de $p$ menores que $0,05 \%$.

\section{Resultados}

\subsection{Amplificação do gene $p s 2$ por PCR}

O gene ps2 foi obtido após amplificação por PCR a partir do uso de iniciadores específicos, os quais adicionaram em cada extremidade amino terminal ( $\mathrm{N}$-terminal) e carbóxi terminal (C-terminal) do gene sítios de reconhecimento para enzimas de restrição, como BamHI e HindIII, respectivamente. Após reação de PCR o DNA foi visualizado em gel de agarose após eletroforese, o que confirma a amplificação, pois o fragmento referente ao gene ps 2 aparece no tamanho esperado de $1.100 \mathrm{pb}$, como é mostrado na Figura 14. 


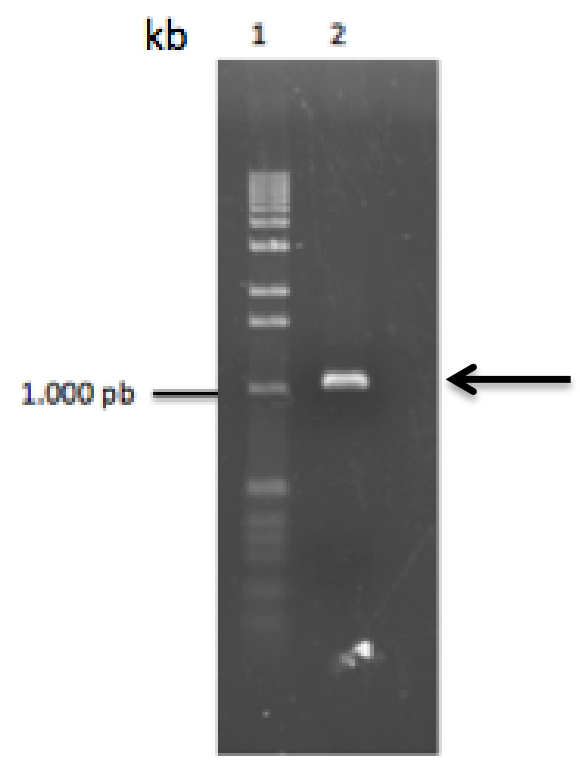

Figura 14. Confirmação da amplificação do gene ps 2 por PCR. Gel de agarose 0,8\% mostrando fragmento de DNA correspondente à amplificação do gene $p s 2$ por PCR com o uso de oligonucleotídeos específicos. (1) - 1kb DNA ladder Invitrogen; (2) - Fragmento de DNA ( 1.100 pb) ampificado com os oligonucelotídeos específicos para o gene ps 2 . A seta preta indica o fragmento de $1.100 \mathrm{pb}$ referente ao gene $p s 2$ amplificado por PCR.

\subsection{Construção do plasmídeo pGemPS26xHis}

O gene ps2, após ter sido amplificado, foi clonado no vetor pGemT-easy, gerando o plasmídeo representado na Figura 15.

A clonagem foi confirmada por digestão do DNA do plasmídeo pGemPs26xHis com a enzima de restrição EcoRI. A digestão foi analisada por eletroforese de gel de agarose $0,8 \%$ (Figura 16), onde é possível observar um fragmento de $3.015 \mathrm{pb}$ referente ao vetor pGEMT-easy, e um fragmento de $1.100 \mathrm{pb}$, referente ao gene $p s 2$. Confirmando então a clonagem do inserto no vetor. 


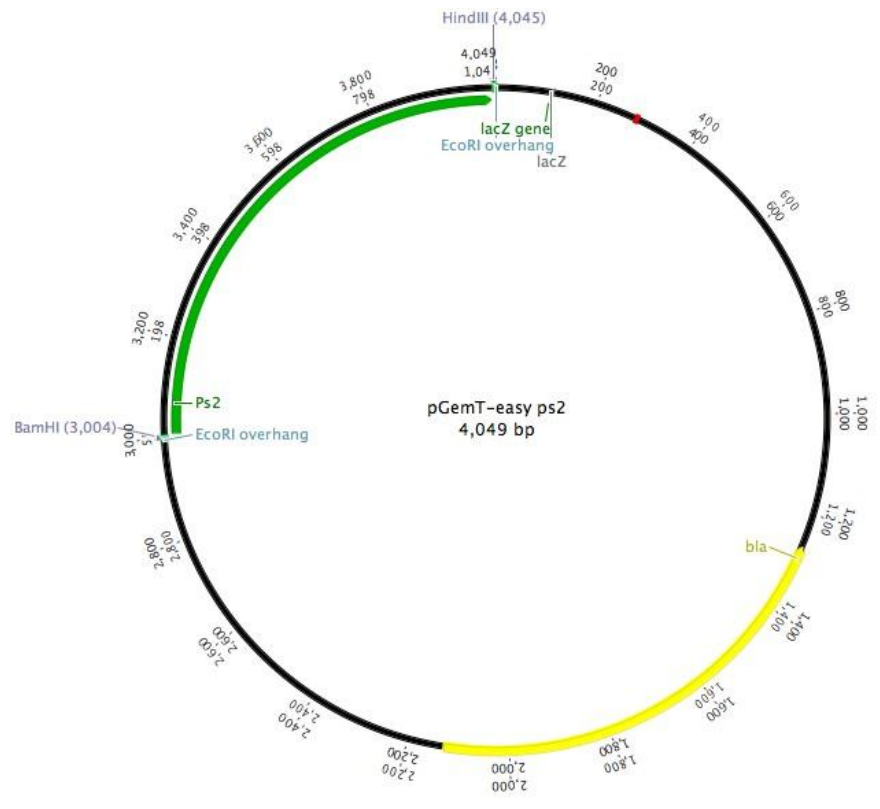

Figura 15. Mapa representativo do plasmídeo pGemPs26xHis. Na figura estão representados três sítios de restrição, sendo os sítios BamHI e HindIII referentes a clonagem do gene de interesse ao vetor, e o sítio de EcoRI referente a confirmação da construção do plasmídeo.

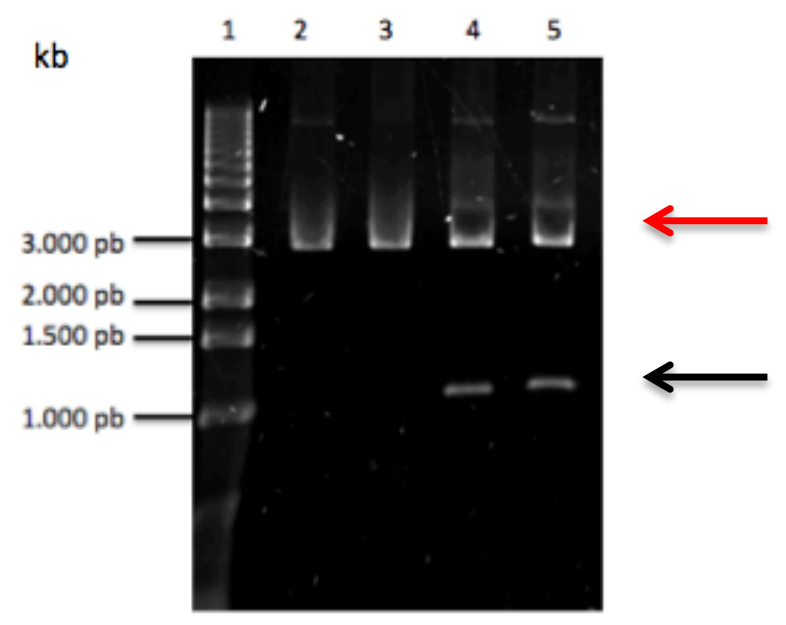

Figura 16. Confirmação da clonagem do gene ps 2 no plasmídeo pGem- Teasy. Gel de agarose $0,8 \%$ mostrando os fragmentos gerados a partir da digestão do DNA do plasmídeo pGemPs26xHis com a enzima de restrição EcoRI, confirmando a clonagem do gene ps2 no vetor pGemT-easy. (1) Marcador $1 \mathrm{~kb}$ ladder Invitrogen. (2) Digestão clone 1 pGem-ps2 1 (EcoRI); (3) Digestão do clone 2 pGem-ps2 2 (EcoRI); (4) Digestão do clone 3 pGem-ps 3 (EcoRI); (5) Digestão do clone 4 pGem-ps 4 (EcoRI), respectivamente. Peso Molecular - pgemT-easy: 3kb (3.015 pb) e gene ps2: $1.1 \mathrm{~kb}(1.100 \mathrm{pb})$. Apenas os clones 3 e 4 liberaram fragmento do tamanho eperado para o gene $p s 2$.

\subsection{Construção do plasmídeo pFastPs26xHis}

Confirmada a clonagem do gene ps2 no vetor pGEMT-easy, o plasmídeo construído (pGemPs26xHis) foi digerido com as enzimas BamHI e HindIII e o 
fragmento correspondente ao gene foi clonado no vetor pFastBac1, que também foi digerido com as mesmas enzimas (Figura 17.)

A clonagem foi confirmada por digestão do DNA do plasmídeo recombinante pFastBacPs26xHis com as enzimas de restrição BamHI e HindIII. A digestão foi analisada por eletroforese de gel de agarose $0,8 \%$ (figura 18), com um fragmento de $4.776 \mathrm{pb}$ referente ao vetor pFastBac1, e um fragmento de $1.100 \mathrm{pb}$, referente ao fragmento de DNA correspondente ao gene $p s 2$.

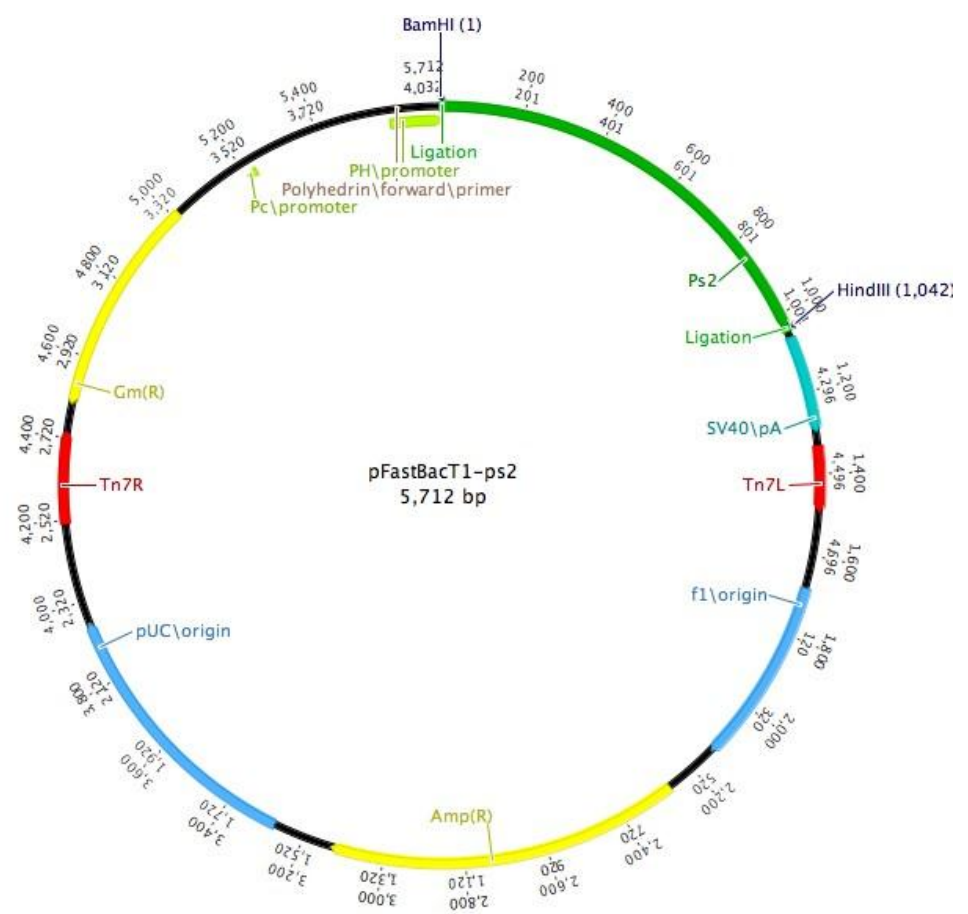

Figura 17. Mapa representativo do plasmídeo pFastPs26xHis. Na figura estão representados os sítios de restrição BamHI e HindIII, os quais foram usados para clonagem e confirmação da construção do plasmídeo. 


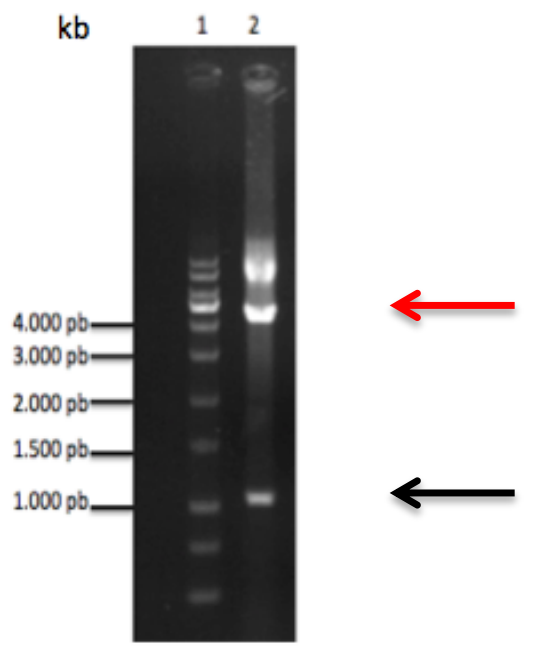

Figura 18. Confirmação da clonagem do gene ps 2 no plasmídeo pFastBac1. Gel de agarose $0,8 \%$ mostrando os fragmentos gerados a partir da digestão do DNA do possível clone com as enzimas BamHI e HindIII, confirmando a clonagem do fragmento de DNA correspondente ao gene ps 2 no vetor pFastBac1. (1) - Marcador $1 \mathrm{~kb}$ ladder Ludwig Biotec; (2) Digestão do DNA do plasmídeo recombinante pFast-ps2 (BamHI e HindIII) . (Tamanho do gene ps2 - $1.100 \mathrm{pb}$; vetor pFastBac: 4,776 bp).

\subsection{Construção do baculovírus recombinante contendo o gene $p s 2$}

O plasmídeo recombinante (pFastPs26xHis) foi usado para transposição sítio específica pelo sistema Bac-to-Bac® (Invitrogen). DNA do Bacmídeo recombinante foi usado para confirmação do vírus recombinante por meio de PCR. A reação de PCR com os primers M13F e M13R foi analisada através de eletroforese em gel de agarose $0,8 \%$ (Figura 19). Clones positivos para o Bacmídeo recombinante amplificam um fragmento de $3.015 \mathrm{pb}(3 \mathrm{~kb})$ 


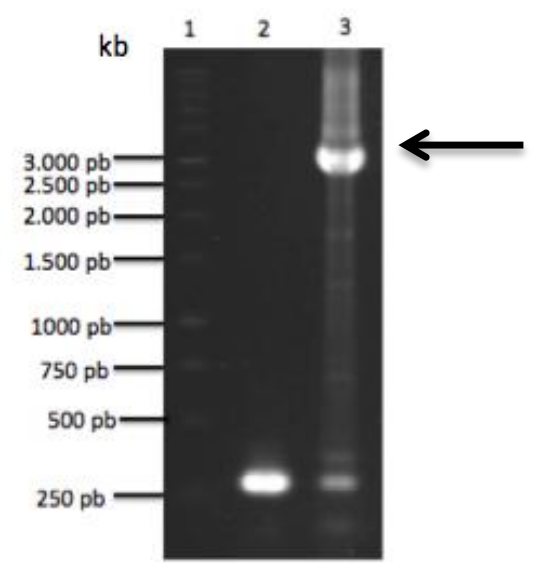

Figura 19. Confirmação da construção do vírus recombinante (Bacmídeo) por PCR usando oligonucleotídeos M13F e M13R. (1) Marcador 1kb ladder promega; (2) Controle negativo (DNA de bacmídeo sem inserto); (3) DNA de bacmídeo contendo o gene $p s 2$. O poço 3 mostra um fragmento do tamanho esperado (3 kb), confirmando a construção do bacmímdeo recombinante. A seta em preto indica o fragmento de $3 \mathrm{~kb}$ referente a amplificação do Bacmídeo contendo om gene $p s 2$.

\subsection{Expressão de proteína PS2 em células de inseto}

O DNA do Bacmídeo recombinante foi usado para transfectar células BTITn5B1-4. Cinco dias pós-transfecção observou-se efeitos citopáticos na célula como hipertrofia nuclear, arredondamento da células, que apresentam-se fusiforme quando não infectadas, e a presença de cristais proteicos formados a partir da expressão da proteína PS2. Com sete dias pós - transfecção as células foram coletadas e foi confirmada a expressão da proteína ps2 (38 kDa) por western blot, como mostrado da Figura 20. 


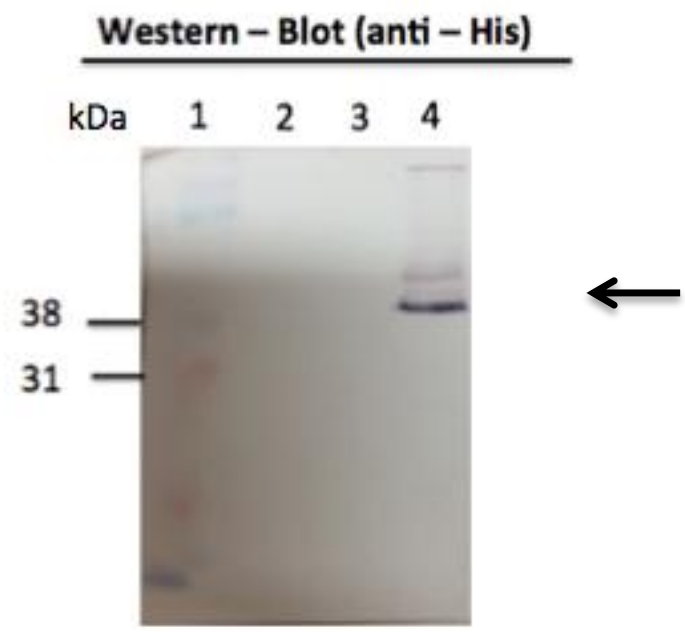

Figura 20. Confirmação da expressão de PS2 em células de inseto. Membrana de nitrocelulose mostrando a marcação, por western - blot, das proteínas recombinates PS2 em extrato de célula SF9 (1) High-Range Rainbow Molecular Weight Markers (GE Healthcare); (2) - Extrato de células Sf9 não infectadas (controle); (3) - Extrato de células Sf9 infectadas com vírus selvagem; (4) - Extrato de células Sf9 proveniente da transfecção com vírus recombinante vAcPS2His.O anticorpo anti-his foi utilizado para marcação da proteína recombinante. A seta indica a marcação da PS2 com o tamanho esperado de $38 \mathrm{kDa}$.

\subsection{Cinética de expressão da proteína recombinante e visualização de cristais em célula de inseto.}

Como observado na transfecção, o vírus recombinante vAcPs2His, ao infectar células de inseto expressa a proteína PS2 e esta foi capaz de produzir cristais posivelmente da protéina recombinante (dados nâo mostrados). Sendo assim, foi realizado um ensaio de cinética de expressão da proteína recombinante por Western blot (Figura 21B), e as mudanças morfológicas analisadas por microscopia de luz (Figura 22). Observou-se que, no tempo de 24 h.p.i ainda não havia formação de cristais, mas que a partir de 48 h.p.i já era possível detectar a protéina recombinante por Western-blot e a formação de cristais pela microscopia (Figura 22 B-C). É observado que, além do polipeptídeo marcado no tamanho esperado de $38 \mathrm{kDa}$ há também marcações nos tempo de 48, 72 e 96 h.p.i mais acima, o que pode representar formas oligoméricas da proteína 
não solubilizada. Em tempos mais tardios (72 e 96 h p.i.) é possível observar uma grande quantidade de células mortas (Figura $22 \mathrm{C}$ e D).

SDS - PAGE ( $5 \%$ concentrador; $12 \%$ separador)

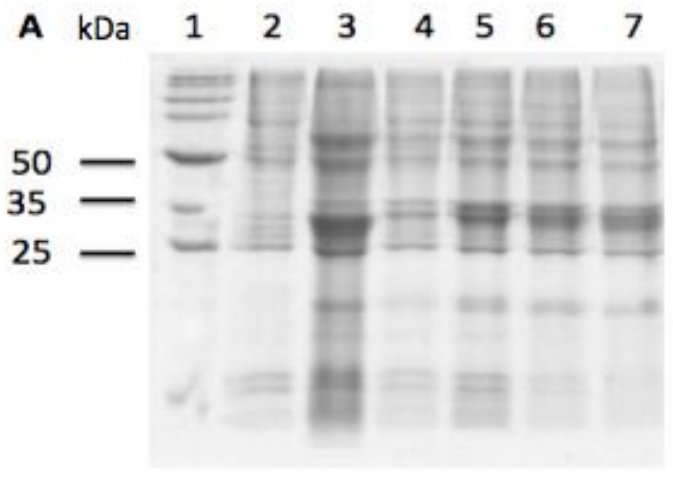

WESTERN - BLOT (anti - His)

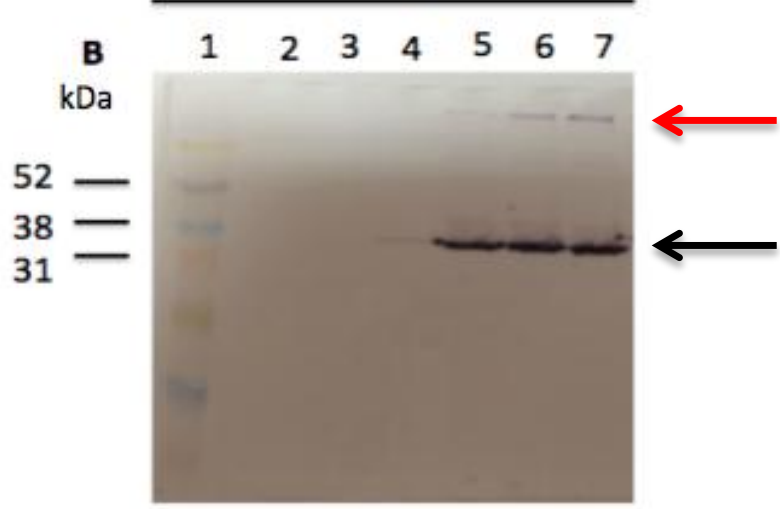

Figura 21. Cinética de expressão de PS2 em células de inseto por SDS - PAGE e Western blot A: (1) Broad Range Weight Markers (Promega Molecular); (2) Controle (extrato de célula sf9 não infectada); (3) Extrato de célula sf9 infectada com vírus selvagem oclusão negativa (vAcocc-); (4) Extrato de célula sf9 infectada com vAcPs26xHis 24 h.p.i; (5) Extrato de célula sf9 infectada com vAcPs26xHis 48 h.p.i; (6) Extrato de célula sf9 infectada com vAcPs26xHis 72 h.p.i; (7) Extrato de célula sf9 infectada com vAcPs26xHis 96 h.p.i.

B: (1) Marcador High-Range Rainbow Molecular Weight Markers (GE Healthcare); (2) Controle (extrato de célula sf9 não infectada); (3) Extrato de célula sf9 infectada com vírus selvagem oclusão negativa (vAcocc-); (4) Extrato de célula sf9 infectada com vAcPs26xHis 24 h.p.i; (5) Extrato de célula sf9 infectada com vAcPs26xHis 48 h.p.i; (6) Extrato de célula sf9 infectada com vAcPs26xHis 72 h.p.i; (7) Extrato de célula sf9 infectada com vAcPs26xHis 96 h.p.i. A seta em preto indica a marcação para PS2 no tamanho de $38 \mathrm{kDa}$ e a em vermelho a possível formação de oligômeros. 

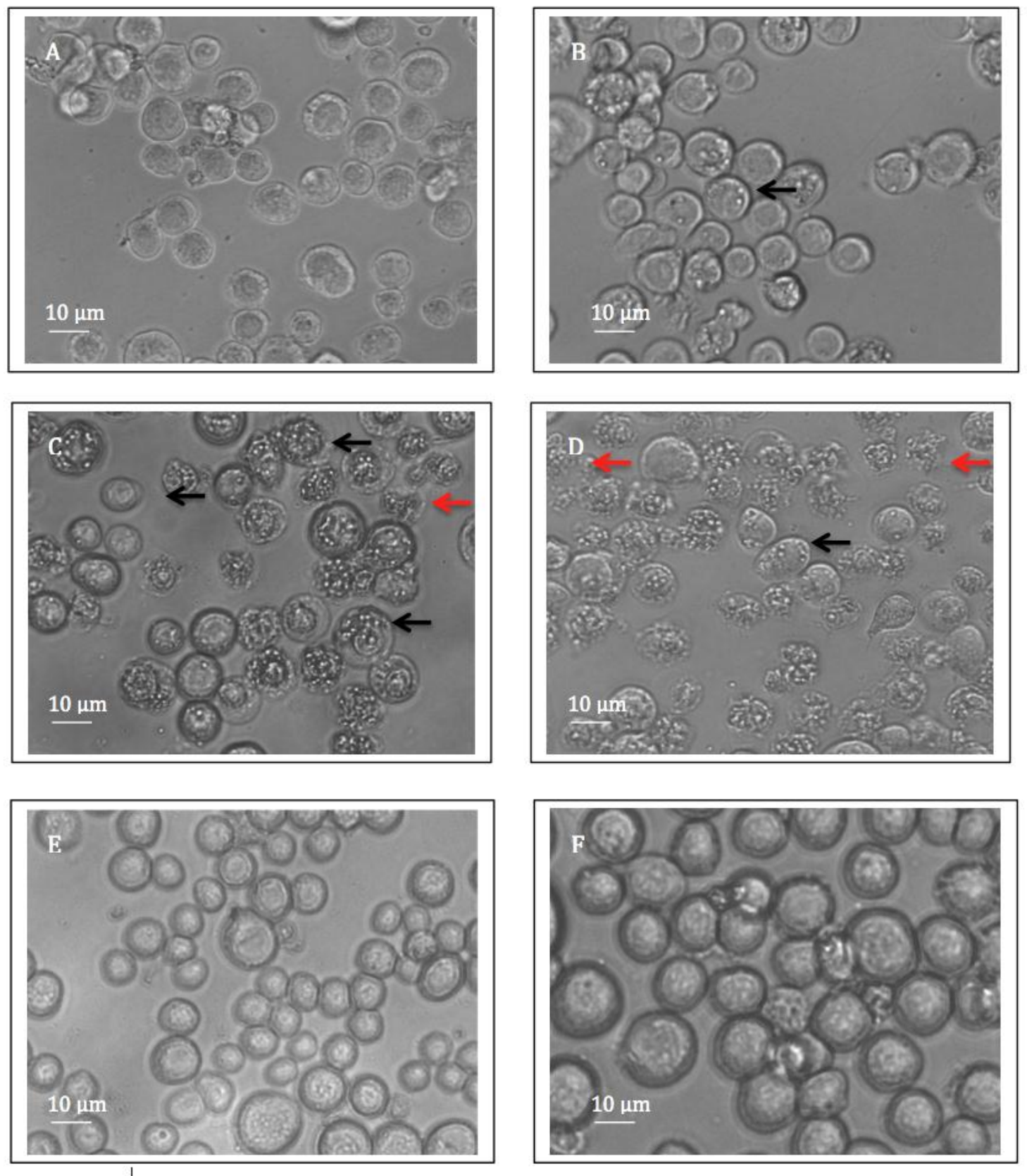

Figura 22. Análise morfológica de células infectadas pelo vírus recombinante por microscopia de luz. (A) Células Sf9 infectadas com vAcps26xHis 24 h.p.i; (B) Células Sf9 infectadas com vAcps26xHis 48 h.p.i; (C) Células Sf9 infectadas com vAcps26xHis 72 h.p.i; (D) Células Sf9 infectadas com vAcps26xHis 96 h.p.i; (E) Células Sf9 infectadas com vírus selvagem oclusão negativa (vAcocc-); (F) Controle - células não infectadas. Setas em preto indicam cristais, e setas em vermelho indicam células em processo de morte ou mortas. 


\subsection{Purificação, solubilização e ativação da toxina PS2.}

A purificação da proteína PS2 foi obtida com sucesso (Comparar poços 2 a 5 na figura 23A). A figura 23B mostra a detecção da proteína PS2 por western blot das proteínas presentes em uma membrana de nitrocelulose derivadas de um gel semelhante ao da figura $23 \mathrm{~A}$.

Quando esta é submetida a solubilização (figura 24, poço 3) é observado que praticamente toda a proteína foi solubilizada (comparar poços 2 e 3).

A figura 25, linha 4 mostra a ativação proteolítica da protoxina PS2 com a ação da proteinase $\mathrm{K}$ que cliva na região amino terminal ( $\mathrm{N}$ - terminal) como na região carbóxi terminal (C- terminal), resultando na diminuição do tamanho da proteína e ativando-a. Uma vez clivada esta perde a cauda de histidina que está presente porção amino terminal, não podendo ser marcada por Western blot.
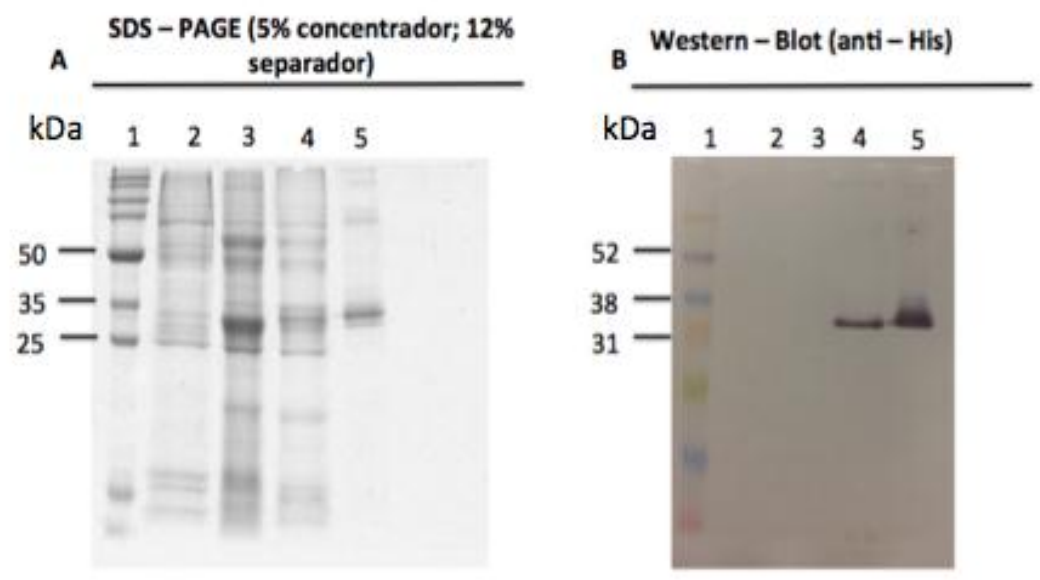

Figura 23. Purificação da proteína PS2. A. SDS-PAGE a 12\% mostrando as frações antes e depois da purificação da proteína PS2, a partir de extrato de células infectadas pelo vírus recombinante. A - (1): Broad Range Protein Weight Markers (Promega Molecular); (2): Controle (extrato de células Sf9 não infectadas); (3): Extrato de células Sf9 infectadas com vírus selvagem oclusão negativa (vAcocc-) (4 ): Extrato de células infectadas com vírus recombinante vAcPS2His 72 h.p.i; (5): protoxina PS2 purificada. B - Western blot referente a um gel semelhante ao mostrado em A (1): High-Range Rainbow Molecular Weight Markers (GE Healthcare); (2): Controle (Extrato de células Sf9 não infectadas; (3): Extrato de células Sf9 infectadas com vírus selvagem oclusão negativa (vAcocc-); (4) Extrato de células Sf9 infectas com vírus recombinante vAcPS2His 72 h.p.i (5 ): pro toxina PS2 purificada. 


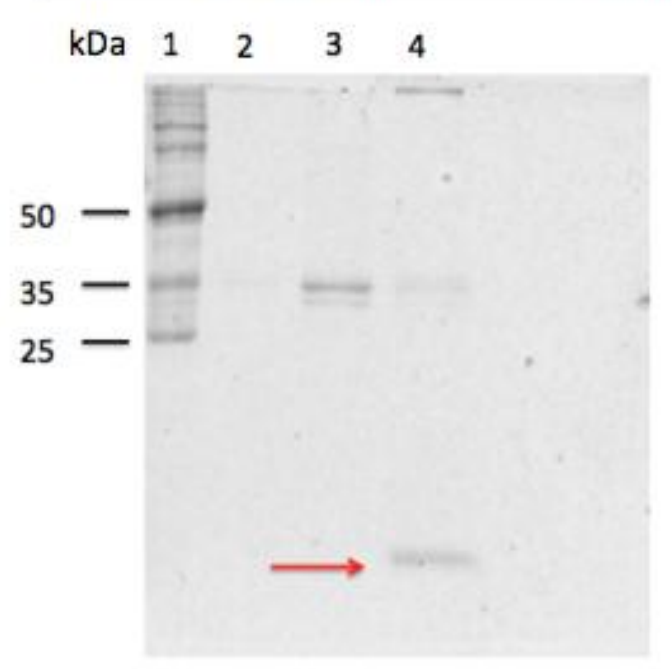

Figura 24. Solubilização e ativação da protoxina PS2. SDS-PAGE a 12\% mostrando a presença da proteína PS2 após solubilização e ativação por proteinase K. (1) Broad Range Protein Weight Markers (Promega Molecular); (2) - porção insolúvel proveniente do processo de solubilização; (3) protoxina PS2 solubilizada; (4) toxina PS2 após ativação proteolítica com proteinase K. [Seta em vermelho indica o fragmento liberado após a clivagem proteolítica].

\subsection{Caracterização ultraestrutural dos possíveis cristais da proteína PS2.}

Após semipurificação dos possiveis cristais da proteína PS2, estes foram preparados para microscopia eletrônica de varredura (MEV) (Figura 25). Podemos observar a forma arredondada dos cristais por volta de $1 \mu \mathrm{m}$ em diâmetro. 


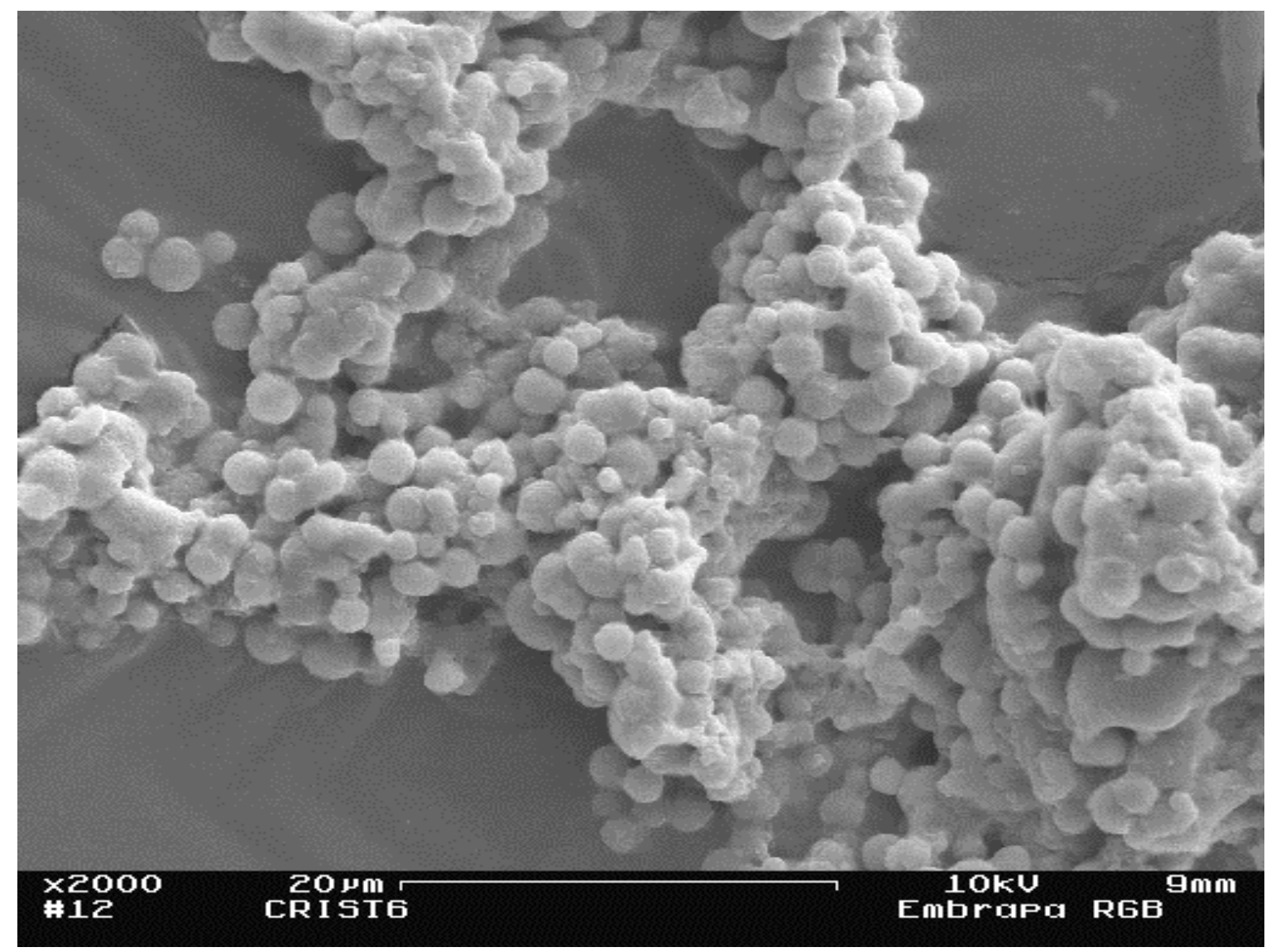

Figura 25. Caracterização ultraestrutural de possíveis cristais de PS2. Eletromicrografia de possíveis cristais de PS2 produzidos em célula de inseto após semipurificação com 0,5\% de SDS e 0,5 M de $\mathrm{NaCl}$ (Miller Dawes, 1978).

\subsection{Ensaio de citotoxicidade em células de inseto}

Foi observado por microscopia de luz (Figura 22), que células de inseto, quando infectadas com o vAcPS2His morriam mais rápido em relação ao vírus selvagem (vAcocc-). Por esse motivo foi realizado um ensaio de viabilidade celular (Figura 26), pelo método do MTT para comprovar essa hipótese. Sendo assim, células de inseto foram infectadas com o vAcPS2His e como controle negativo foi usado o vAcocc-. Vale ressaltar que os valores de absorbância medidos para cada tratamento e tempo de infecção foram comparados com valores de absorbância de células não tratadas (controle), ou seja, células que apresentam 100\% de viabilidade. O gráfico (Figura 26) mostra que o vAcPS2His mata mais rápido que o vírus selvagem, onde valores desse vírus para os tempos de 48 h, 72 h e 96 h.p.i são significativamente mais baixos que o do vírus selvagem. 


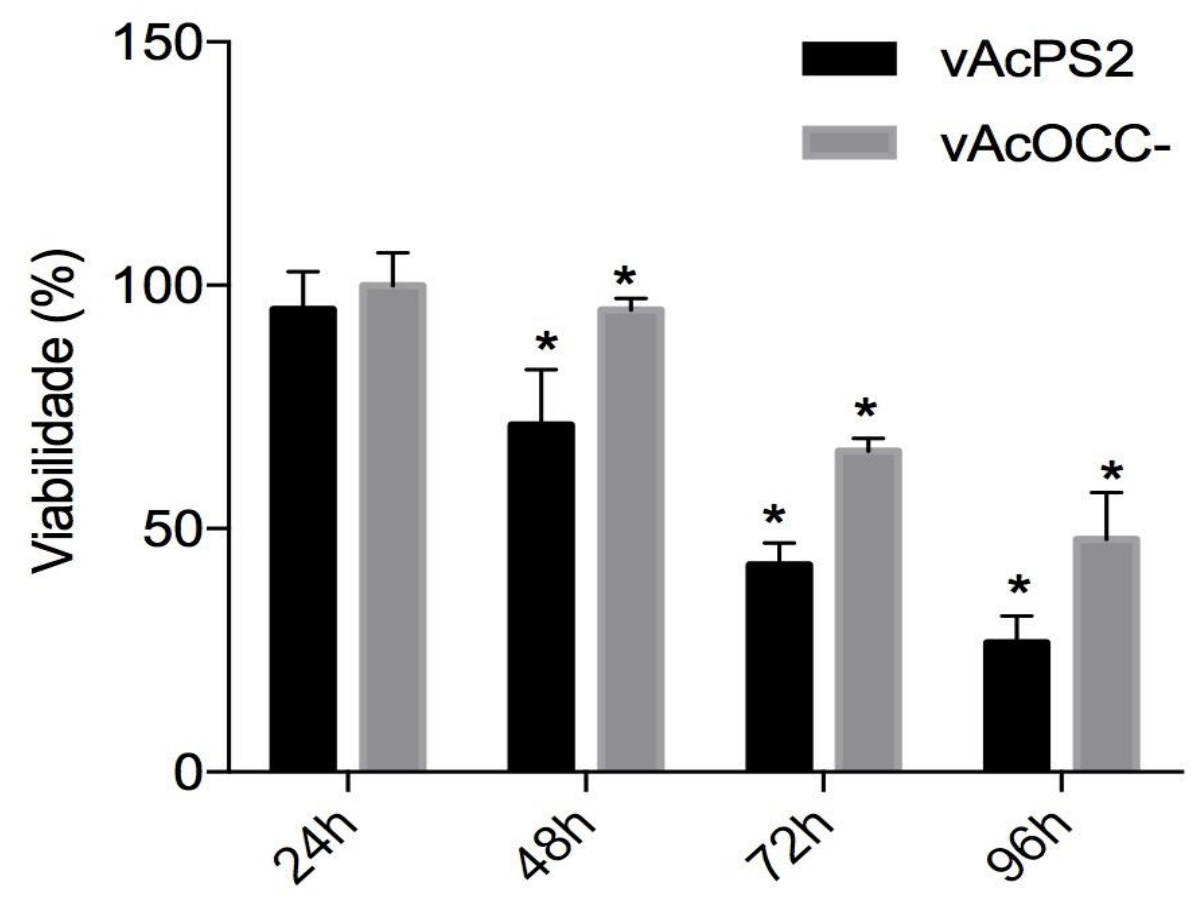

Figura 26. Análise da viabilidade celular em células SF9 infectadas pelos vírus recombinantes vAcPS2His e vAcocc-. Células de inseto Sf9 infectadas com vAcPS2His e vAcocc- (controle negativo) com MOI 5 para medida de viabilidade celular por MTT em tempos diferentes de infecção, 24h; 48h; 72h; 96h. O dados foram analisados usando o teste students-T pelo programa GraphPad Prism 7. $(<0,0001 *)$ 

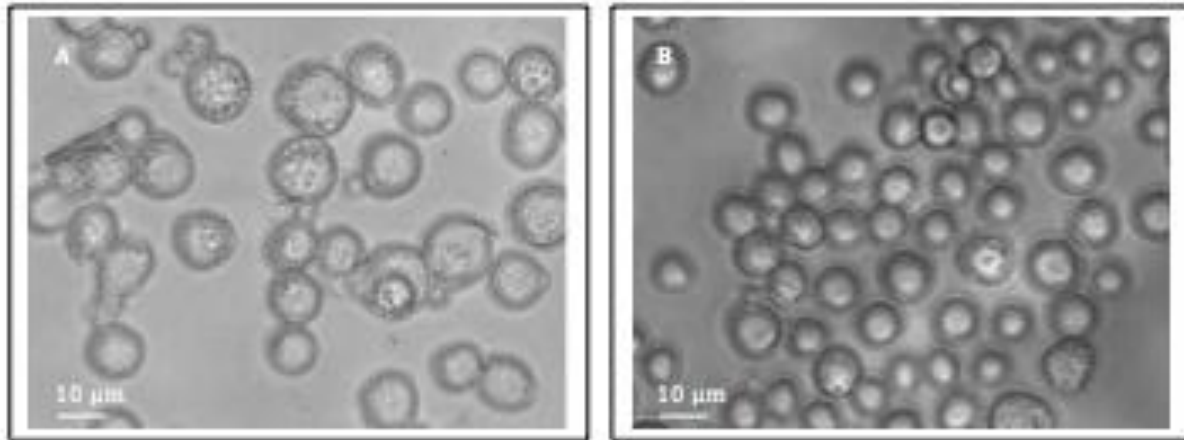

$\frac{\sqrt{2}}{5}$
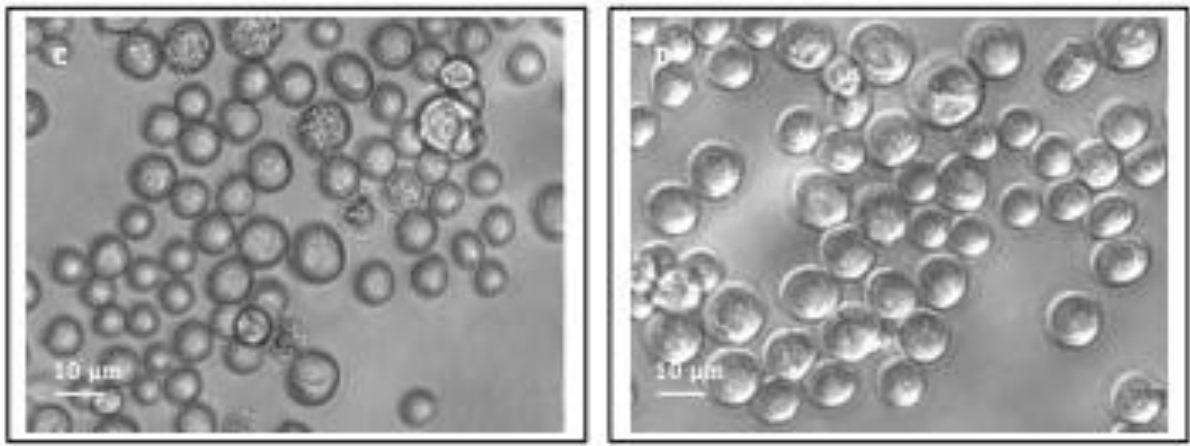

함
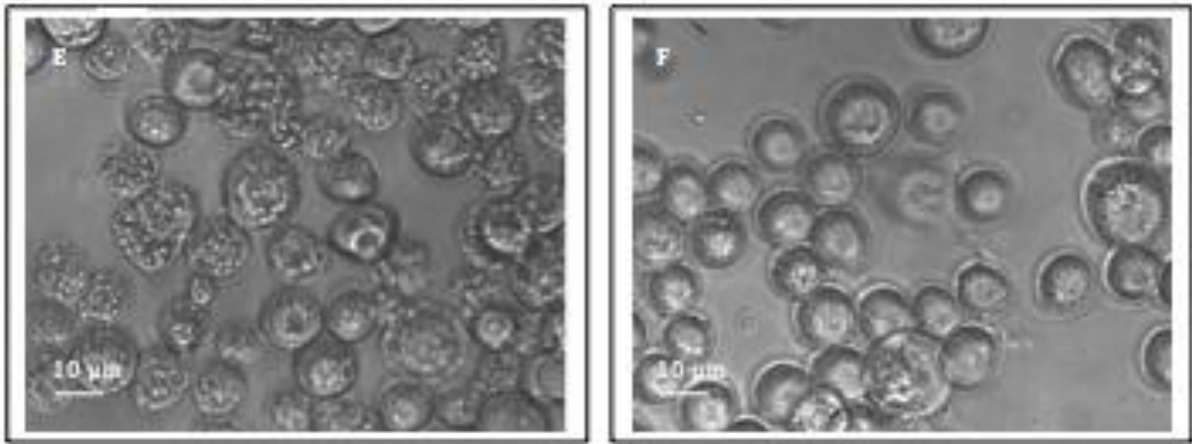

골
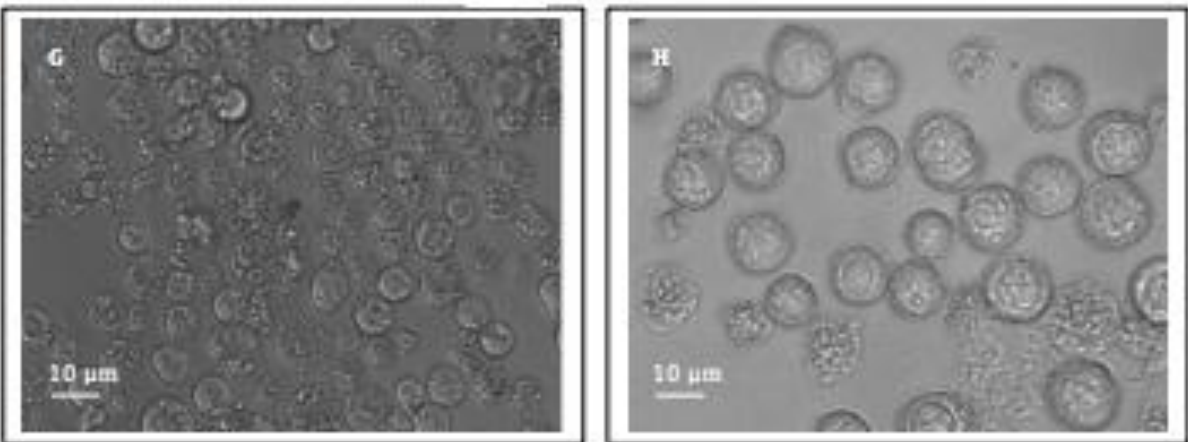

욤.

Figura 27. Análise morfológica de células de inseto infectadas pelos vírus reombinantes em diferentes tempos pós-infecção. Células de Sf9 foram infectadas pelos vírus recombinantes vAcPS2his (A,C, E, G) e vAcocc- (B,D,F,H) e analisadas por micriscopia de luz nos tempos 24 h; 48 h; 72 h; 96 h. 
É possível observar (Figura 27), com o auxílio da microscopia de luz, que células Sf9 quando infectadas com os vírus vAcPS2His e vAcocc- morrem em tempos diferentes, confirmando o resultado mostrado na figura 26.

\subsection{Ensaio de viabilidade em células de inseto}

Com o intuito de confirmar o fato de que células de inseto tratadas com a toxina PS2 não sofrem com a ação da proteína, ou melhor, a proteína não tem atividade sobre elas, foi realizado o ensaio de viabilidade celular por meio da técnica de MTT. As células de inseto foram tratadas com PS2 nas concentrações de $0,1 \mu \mathrm{g} / \mathrm{mL}$ a 2,0 $\mu \mathrm{g} / \mathrm{mL}$ e foi observado (Figura 28) que após 24 h de tratamento PS2 não causa morte das células de inseto, ou seja, PS2 quando não é expressa dentro da célula não apresenta toxicidade para as células Sf9.

Observou-se também, por microscopia de luz, que após células de inseto SF9 serem tratadas com a proteína PS2 de B. thuringiensis (figura 29A - 29E) não houve qualquer mudança morfológica, assim nas células que foram incubadas com o diluente (figura 29F) da proteína (PBS $1 \mathrm{X}+0,1 \mathrm{mM}$ PMSF), quando comparadas com células não tratadas (figura 29G). Sendo assim, conclui-se que PS2 não apresenta atividade tóxica para células de inseto SF9. 


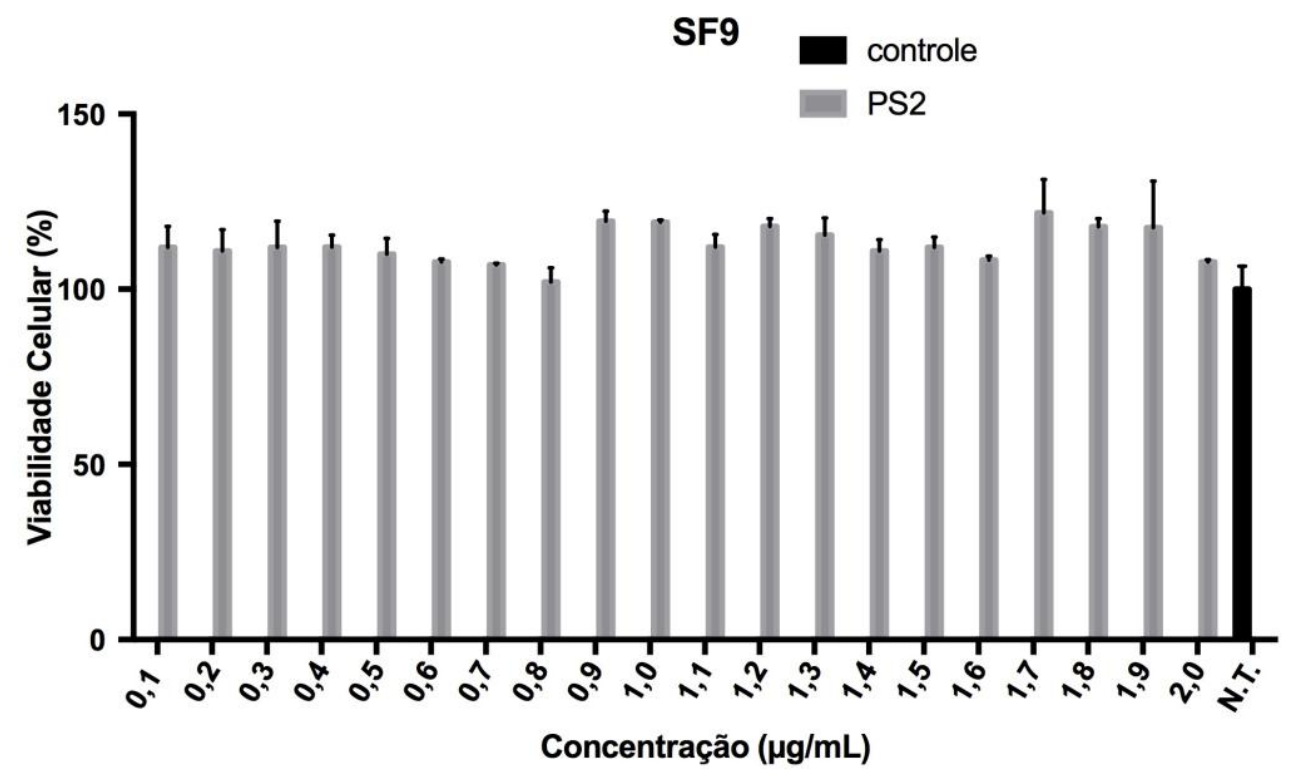

Figura 28. Viabilidade de celulas Sf9 tratadas com PS2 por 24 h. Ensaio de MTT de Células de inseto Sf9 tratadas com a proteína PS2 por 24 horas nas concentrações $0,1 \mu \mathrm{g} / \mathrm{mL}$ a 2,0 $\mu \mathrm{g} / \mathrm{mL}$. A análise estatística foi pelo Teste de students-T pelo programa GraphPad Prism 7. (<0,0001*)

\subsection{Ensaio de viabilidade em células tumorais}

Células tumorais de mama (MCF-7 e MDA-MB-231) e células não tumorais (Fibroblasto) também foram tratadas com PS2 nas concentrações $0,1 \mu \mathrm{g} / \mathrm{mL}-2,0$ $\mu \mathrm{g} / \mathrm{mL}$ e a viabilidade de ambas foi medida pelo ensaio de MTT.

A figura 30A mostra que a linhagem celular em estudo (MCF-7) é sensível a ação da toxina. Após a concentração de $1,1 \mu \mathrm{g} / \mathrm{mL}$ PS2 mata mais de $50 \%$ das células em cultura, sendo estatiscamente significativo quando comparado com o controle do experimento, células não tratadas. Em contra partida, células MDA-MB-231 são menos sensíveis que as células anteriores, onde nas concentrações em estudo PS2 não provocou mortalidade nem de $30 \%$ das células (figura 30B), sendo a porcentagem de morte não significativa quando comparada com o controle na análise estatística. Fibroblastos, células não tumorais, foram usados como controle para mostrar que PS2 não é tóxica. A figura 30C mostra que para todas as concentrações testadas, em nenhuma delas há porcentagem de células mortas, quando tratadas com PS2, ou seja, a 
toxina em estudo não apresenta toxicidade para células de fibroblastos humanos. Dados da viabilidade de células tratadas com o diluente (PBS 0,1X + PMSF 0,01 mM) não foram plotados no gráfico mas é possível observar (Figuras 31P,Q,R), por meio de microscopia de luz que não houve qualquer modificação na morfologia das células.

$0,1 \mu \mathrm{g} / \mathrm{ml}$

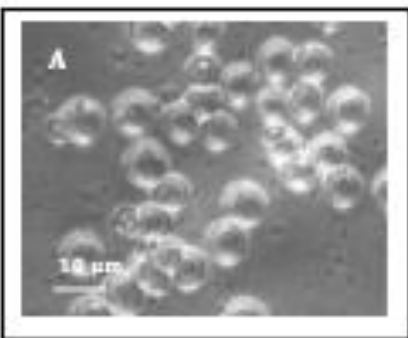

$1,5 \mu \mathrm{g} / \mathrm{ml}$

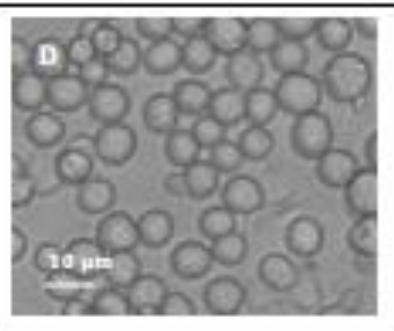

PBS

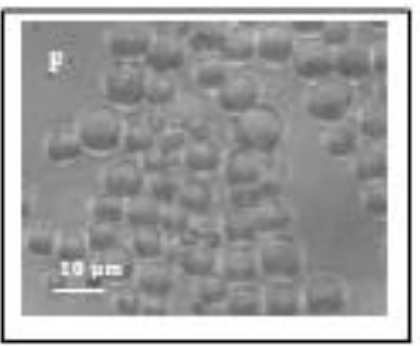

$0,5 \mu \mathrm{g} / \mathrm{ml}$

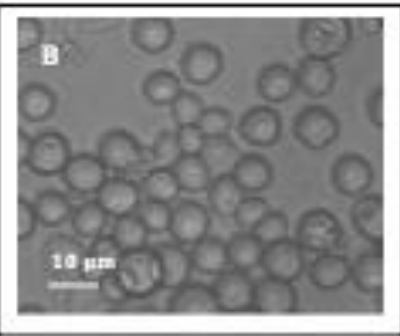

$2,0 \mu \mathrm{g} / \mathrm{ml}$

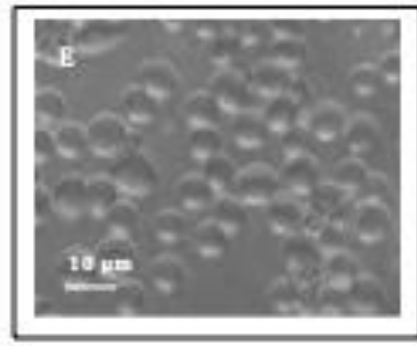

NT

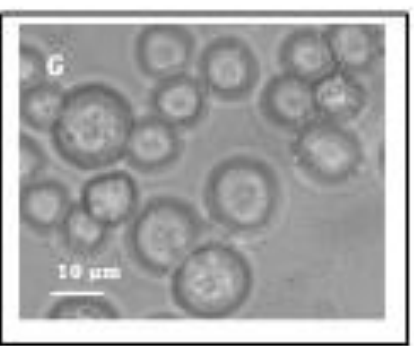

$1,0 \mu \mathrm{g} / \mathrm{ml}$

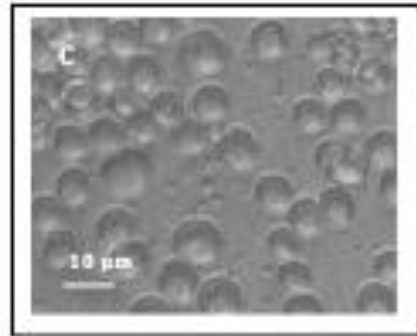

㖞

$\frac{n}{3}$

Figura 29. Análise estrutural de células Sf9 tratadas com a proteína recombinantes PS2. Na figura estão representadas algumas concentrações de tratamento com PS2 para mostrar a atividade da proteína nas células de inseto. A, B, C, D, E nostram células de inseto Sf9 tratadas com PS2 nas concentrações de 0,1;0,5;1,0;1,5 e 2,0 $\mu \mathrm{g} / \mathrm{mL}$ respectivamente]. (F) Células de inseto Sf9 tratadas com o diluente (PBS) [2,0 ug/mL]. (G) Células de inseto Sf9 não tratadas (NT). 


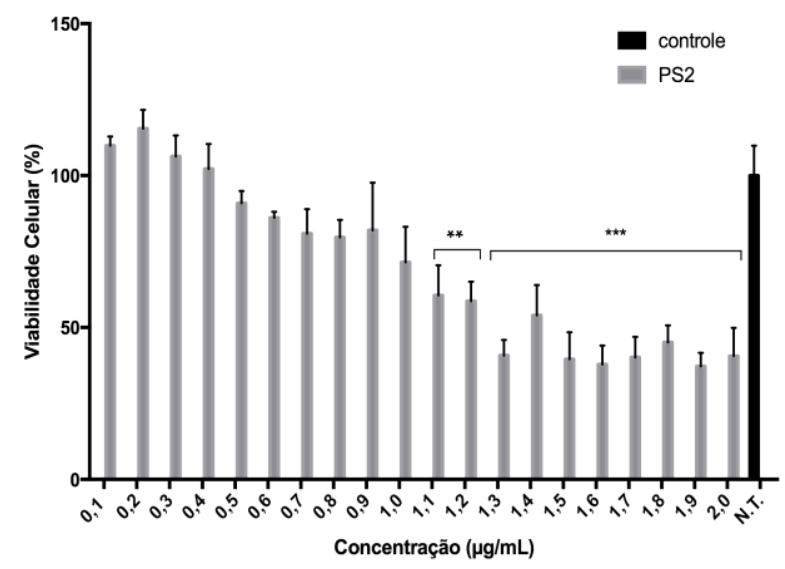

MDA-MB-231
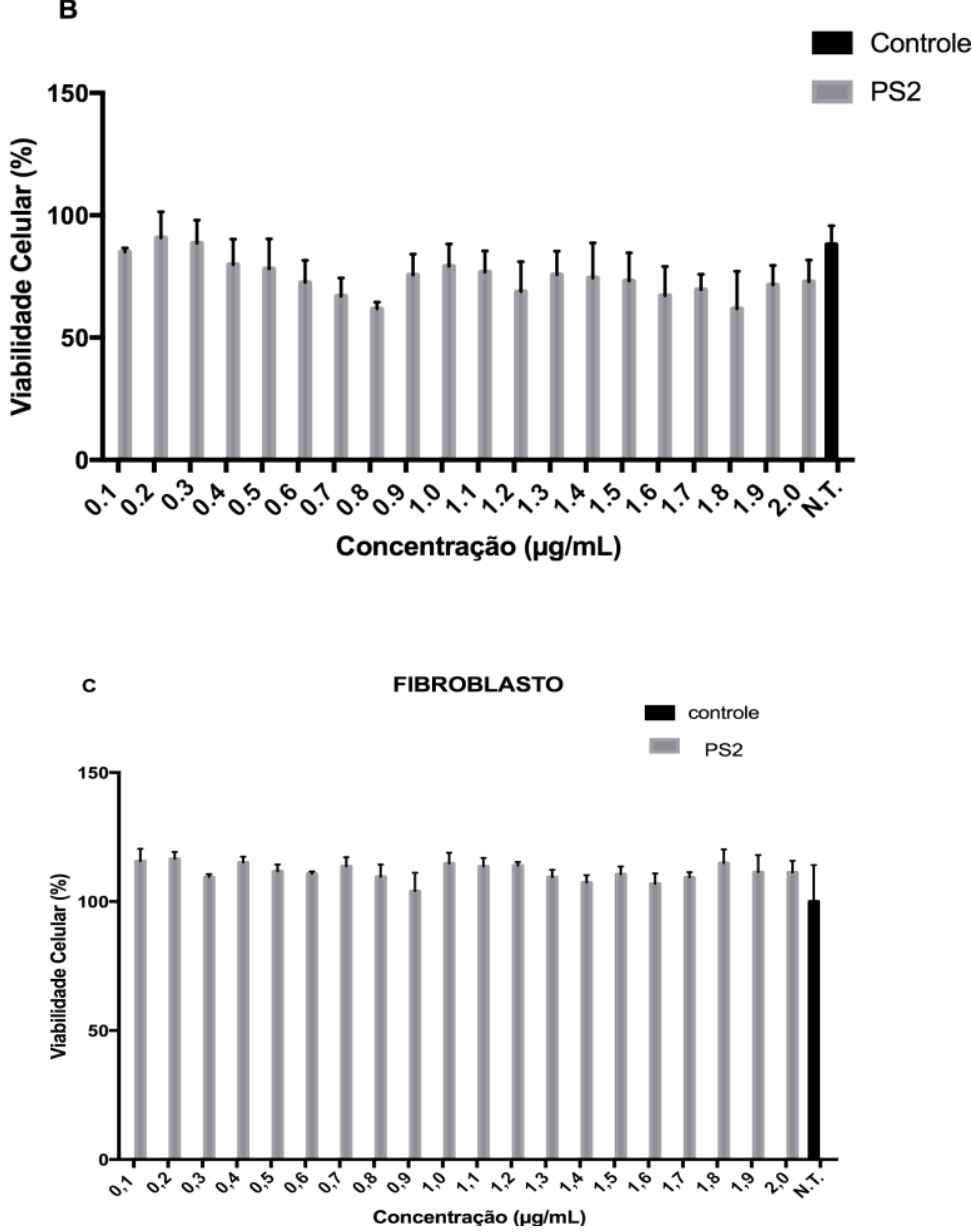

Figura 30. Análise da viabilidade de células tumorais e não tumorais tratadas com PS2. Ensaio de MTT de células tumorais MCF-7 (A), MDA-MB-231(B) e (C) Célula não tumoral (Fibroblasto) tratadas com PS2 por $24 \mathrm{~h}$ nas concentrações $0,1 \mu \mathrm{g} / \mathrm{mL}$ a $2,0 \mu \mathrm{g} / \mathrm{mL}$. Os dados foram analisados usando o teste students-T pelo programa GraphPad Prism 7. $\left(<0,05^{*} ; 0,01 * * ; 0,001 * * *\right)$. 

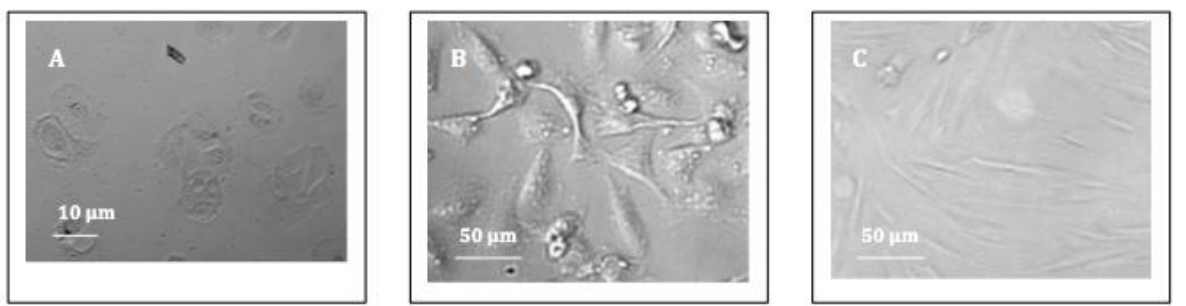

\section{送}
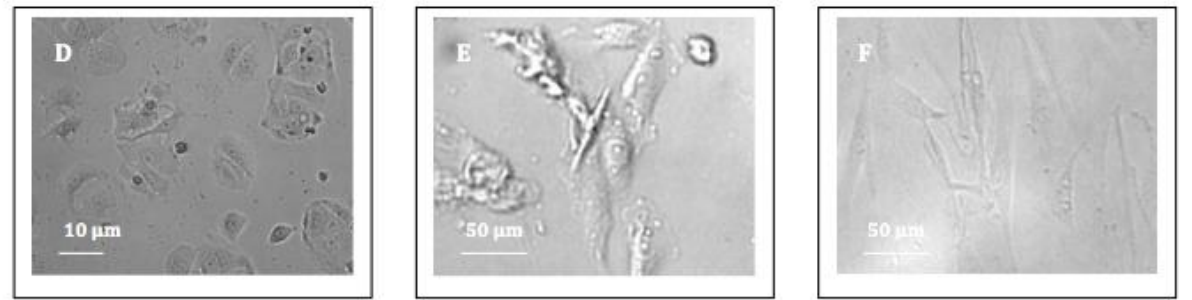

穿
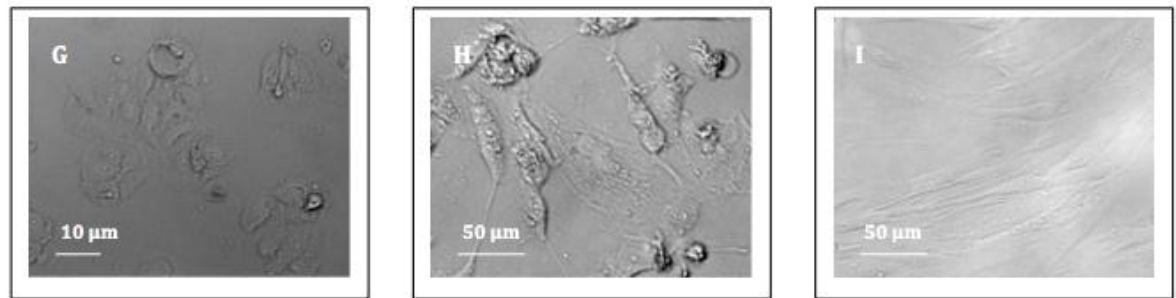

官
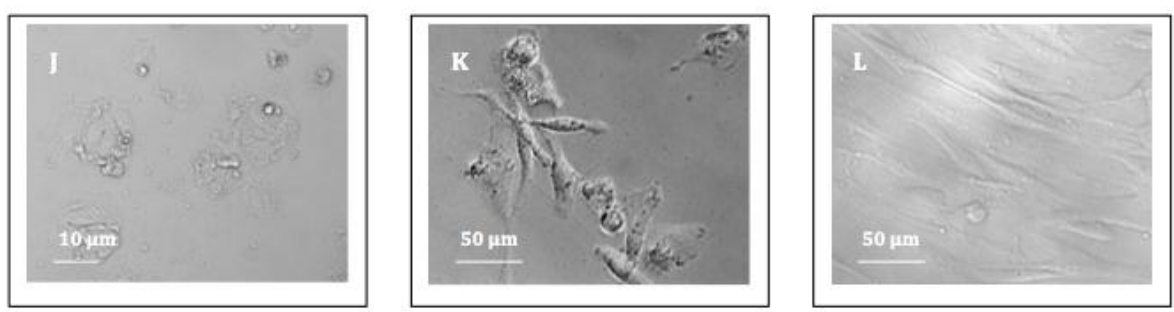

鬲
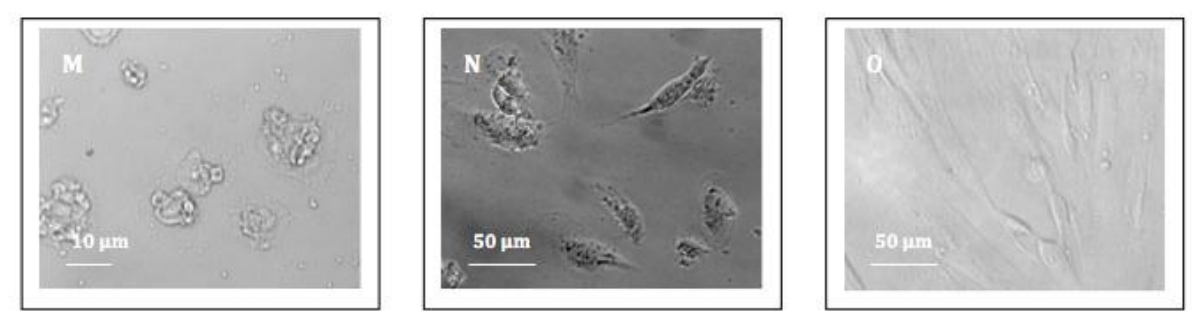

管
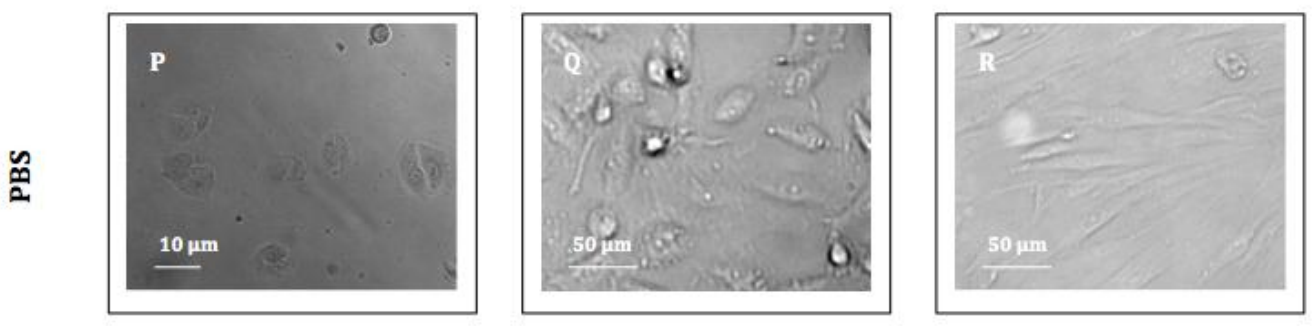

管
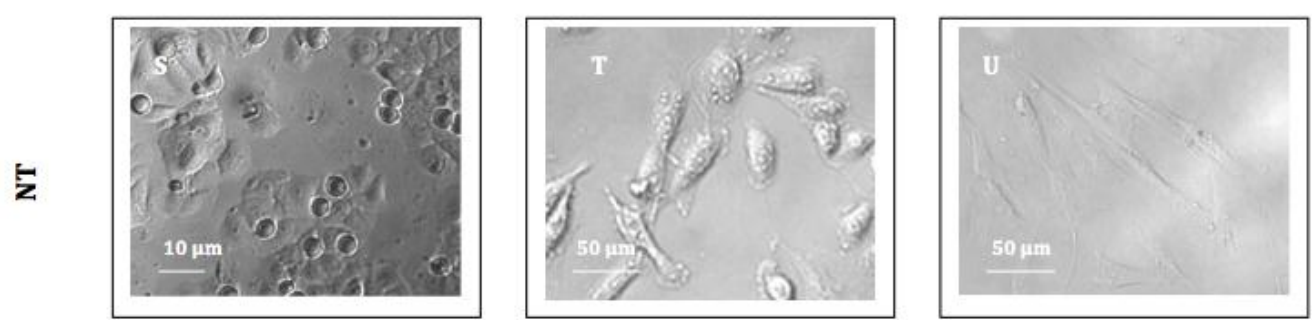

Figura 31. Micrografia de luz de células tumorais e não tumorais humanas tratadas com PS2 em 24h. (A, D, G, J, M): Células tumorais MCF-7 tratadas com PS2 nas $[0,1 \mathrm{ug} / \mathrm{mL}-2,0 \mathrm{ug} / \mathrm{mL}]$ respectivamente. (B, E, H, K, N): Células tumorais MDA-MB-231 tratadas com PS2 nas $[0,1 \mathrm{ug} / \mathrm{mL}-$ 2,0 ug/mL] respectivamente. (C, F, I, L, O) Fibroblasto humano tratado com PS2 nas $[0,1 \mathrm{ug} / \mathrm{mL}-2,0$ $\mathrm{ug} / \mathrm{mL}$ ] respectivamente. $(\mathrm{P}, \mathrm{Q}, \mathrm{R})$ Células tratadas com PMS (diluente da proteína) na maior []. (S, T, U) Células não tratadas (NT). 


\section{Discussão}

O presente trabalho teve como objetivo expressar a proteína PS2 em células de inseto e analisar sua atividade em linhagens de células tumorais. Além disso analisar se esta, mesmo sendo expressa em outro sistema, ainda sim permanece com sua característica principal, a de produzir cristais protéicos (Kitada, S. et al., 2006).

Durante o trabalho, observou-se que, a proteína, quando expressa em células de inseto mantem sua capacidade de produção de cristais (Figura 22B-D). A produção de cristais por B. thuringiensis é a principal característica que distingue essa espécie de Bacillus das outras espécies (Sezen et al., 2010), sendo que essas estruturas cristalinas podem conter protéinas responsáveis pela toxicidade para determinados insetos ou outros organismos (Tailor et al., 1992; Lereclus et al., 1993; Habib \& Andrade, 1998). Como forma de caracterização dos cristais recombinantes, foi realizada microscopia eletrônica de varredura (MEV) e visualizadas várias estruturas esféricas (Figura 25) diferentemente do que detectado em quando PS2 foi expressa em Escherichia ecoli pelo sistema de expressão Gateway Technology® (Kitada, S. et al., 2006).

A solubilização e ativação natural de PS2 ocorrem da mesma forma que as proteínas Cry. Essas protéinas são solubilizadas pelo suco alcalino do intestino médio do inseto, sendo posteriormente ativadas por proteinases específicas (Hofte et al., 1989). Kitada e colocaboradores (2006) mostraram, por meio de estudos feitos em células HepG2, que a ativação por proteinase $\mathrm{K}$ nas regiões amino e carbóxi terminais são importantes para a atividade tóxica de PS2. Foi mostrado que PS2, quando ativada proteoliticamente pela ação de proteases gera uma toxina ativa com tamanho de $30 \mathrm{kDa}$, a partir de uma protoxina de 37 kDa (Kitada, S. et al., 2006; Abe et al., 2008; Kitada, S. et al., 2009 ), porém no presente trabalho a digestão com proteinase $\mathrm{K}$ gerou um 
fragmento menor (Figura 24). Acredita-se que seja devido ao fato da proteína ter sido expressa em um sistema diferente do seu sistema natural, que é o sistema procariótico (B. thuringiensis ou E. Coli) (Kitada, S. et al., 2006), diferente do sistema de expressão em célula de inseto, um sistema eucarioto em que apresenta-se mais complexo, podendo ocorrer modificações pós traducionais nas proteínas produzidas (O’Reilly, et al., 1992). Sendo assim, pode ser que a PS2, quando expressa por esse sistema sofra algumas modificações que permitam essa diferença na clivagem com proteinase $\mathrm{K}$.

Durante o ensaio de cinética de expressão de PS2 em células de inseto (figura 22B) foi observado a possível formação de oligômeros, os quais resistiram à ação de SDS e $\beta$ - mercaptoetanol, ambos usados no processo de desnaturação da proteína para SDS-PAGE. Abe et al. (2008) mostraram, através de SDS-PAGE e western blot a formação de possíveis oligômeros de PS2, após células HepG2 serem tratadas com a proteína. Ao longo do trabalho mostraram que a formação de oligômeros estava localizada na membrana e que os oligômeros estavam relacionados com a formação de poros na membrana da célula, desencadeando a morte da mesma. Kitada et al. (2009) mostraram mais tarde que os oligômeros formados estão relacionados com a toxicidade da PS2, umas vez que eles são formados na superfície da membrana celular de células tumorais HepG2a, nas jangadas lipídicas, e que posteriormente ligavam-se a proteínas ancoradas a GPI. Os microdomínios de membranas enriquecidos de lipídeos também estão envolvidos na ligação de agentes patógenos, como vírus, bactérias e protozoários, onde os possíveis recepetores para as toxinas estão presentes (Mañes, S. et al., 2003). Toxinas formadoras de poros são o tipo de toxina de bactéria conhecida por terem como alvo, as jangadas lipídicas, acumular-se e oligomerizar-se, a ponto de penetrar na membrana e formar poros na membrana (Geny, B. et al., 2006; Tilley, S. et al., 2006).

Quando células de inseto foram infectadas com o vírus recombinante vAcPs2His, foi observado um aumento da velocidade de morte celular quando 
comparado com a infecção do vírus selvagem. Saitoh et al. (2006), demonstraram que proteínas parasporina não apresentam especificidade para células de inseto como as proteínas Cry de B. thuringiensis, e sim somente para células de câncer humano. De acordo com o trabalho de Kitada et al. (2006) onde é mostrada a importância de clivagem nas porções amino e carbóxi terminal, sugere-se neste trabalho, que quando a proteína em estudo (PS2) é expressa pelo vírus dentro da célula de inseto, a mesma pode sofrer clivagem, através de proteases presentes na célula de inseto, tornando-a uma proteína ativa, permitindo-a exercer suas funções na célula, bem como levar a morte da célula. Nesse trabalho, confirmamos (Figura 28) a ausência de toxicidade de PS2 para célula de inseto após solubilização e ativação da protéina in vitro. Acredita-se então que o fato da PS2 ser expressa dentro da célula faz com que essa etapa de reconhecimento a receptores específicos localizados na superfície da membrana do inseto não seja necessária, uma vez que ela já se encontra dentro da célula, podendo então de alguma forma desencadear o processo de morte celular. Há também a possibilidade dela ser ativada proteolicamente por diversas proteases presentes nas células de inseto e essa ativação pode ser diferenciada o que permite que ela tenha tal atividade.

Além da hipótese de PS2 induzir a formação de poros, pela ligação a proteínas ancoradas a GPI, um recente trabalho realizado por Brasseur et al. (2015), mostrou que esta proteína é capaz de induzir a apoptose em células tumorais pela detecção da ativação das caspases 3-7. Os pesquisadores questionaram o fato de células, após o tratamento com PS2, não apresentarem o mesmo padrão morfológico de morte, como aumento da célula e formação de corpos apoptóticos, proposto em outros trabalhos (Kitada et al., 2006; Abe et al., 2008) e sim a diminuição da célula, apresentando-se de forma enrugada, o que achamos semelhante (Figura $22 \mathrm{C}$ e D) quando células de inseto são infectadas pelo vírus recombinante vAcPS2his. Sendo assim, sugere-se também que células de inseto, quando infectadas com o vírus recombinante e a proteína PS2 é 
expressa dentro da célula, esta pode desencadear um processo de morte por apoptose. Vale ressaltar a necessidade de experimentos que testem a ativação de PS2 por proteinases do inseto assim como ensaios para saber se a toxina é capaz de induzir a morte por apoptose, assim como induz em células tumorais.

Estudos anteriores (Ito et al., 2004; Akiba, et al., 2009) já mostraram que PS2 apresenta-se como uma proteína com caráter tóxico para células tumorais, sendo assim, no presente trabalho a toxina foi testada em duas linhagens de célula tumoral de mama, MCF-7 e MDA-MB-231, com o intuito de confirmar a ação dessa proteína, visto que a mesma foi expressa em um novo sistema, e que ainda não há trabalhos publicados de expressão de parasporinas no sistema de expressão de células de inseto.

Em todo o mundo, o câncer de mama (CM) é o tipo de neoplasia maligna que mais acomete as mulheres, tendo como o principal fator de risco o envelhecimento, não descartando outros fatores de risco como aqueles relacionados com a vida reprodutiva da mulher (menarca precoce, primeira gestação após os 30 anos de idade, uso de anticoncepcionais orais, menopausa tardia e reposição hormonal), e também causas genéticas, onde são observadas alterações em genes relacionados ao metabolismo hormonal e ao reparo do DNA (Stuchey, 2011: Abdulkareem \& Zurmi, 2012).

Os resultados obtidos nesse trabalho com o tratamento de células tumorais (MCF-7 e MDA-MB231) corroboram os resultados obtidos por outros autores (Brasseur et al.,2015). Já em células MDA-MB231, também linhagem de célula de câncer de mama, no caso metastática, esta apresentou-se ser menos sensível à toxina PS2 (Figura 30B), como também foi mostrado no estudo feito por Brasseur et al. (2015), onde PS2 possui uma menor atividade tóxica em células MDA-MB231. Quando células não tumorais (fibroblastos) foram tratadas com PS2, nas mesmas concentrações, as células continuaram viáves (Figura 30C), ou seja, PS2 não apresentou a atividade para células esse tipo celular, pois esta, possivelmente, não apresenta receptores específicos em suas 
membranas, ocasionando na não ligação de PS2. No trabalho de Kitada et al. (2006) foi mostrado, através de cortes histológicos, que PS2 localiza-se na região membranosa de células HepG2, mas em células não tumorais, caso fibroblasto, esse fato não acontece.

\section{Perspectivas}

- Medir, através de citômetro de fluxo, os níveis de PI e Anexina com o intuito de saber se PS2, quando expressa pelo vírus, induz a célula de inseto a apoptose.

- Realizar ensaio para saber se PS2 é capaz de induzir a ativação das via de caspases em células de inseto e mamíferos;

- Avaliar a clivagem de PS2 através do tratamento com proteases de inseto;

- Construir um vírus recombinante contendo o gene ps2 e também o gene da poliedrina para produção de corpos de oclusão;

- Avaliar ação do vírus recombinante contendo corpos de oclusão em bioensaio com insetos, afim de saber se este mantém a ação de matar mais rápido em relação ao vírus selvagem.

- Testar PS2 produzida pelo sistema de expressão em células de inseto com outras linhagens tumorais.

\section{Referência Bibliográfica}

ABE, Y.; SHIMADA, H.; KITADA, S. Raft-targeting and oligomerization of Parasporin-2, a bacillus thuringiensis crystal protein with anti-tumour activity. $J$. biochem, 143 (2): 269-275, 2008.

AGUIAR, R. W. DE S.; MARTINS, É. S.; RIBEIRO, Bergmann Morais.; MONNERAT, R. G. Cry10Aa Protein is Highly Toxic to Anthonomus grandis Boheman (Coleoptera: Curculionidae), an Important Insect Pest in Brazilian Cotton Crop Fields. Bt Research, V. 3, p. 20-28, 2012.

AGUIAR, R. W.; MARTINS, E. S.; VALICENTE, F.; CARNEIRO, N. P.; BATISTA, A. C.; MELATTI, V. M.; MONNERAT, R. G.; RIBEIRO, Bergmann Morais. A recombinant truncated Cry1Ca protein is toxic to lepidopteran insects and forms large cuboidal crystals in insect cells. Current Microbiology, v. 53, p. 287-292, 2006. 
AIZAWA, K.; ISHIWATA, S. His discovery of sotto-kin (Bacillus thuringiensis) in 1901 and subsequent investigations in Japan. In: Proceedings of a Centennial Symposium Commemorating Ishiwata's Discovery of Bacillus thuringiensis. OHBA, M.; NAKAMURA, O.; MIZUKI, E.; AKAO, T. (eds.). pp. 1-14, 2001.

AKIBA, T.; ABE, Y.; KITADA, S.; KUSAKA, Y.; ITO, A.; ICHIMATSU, T.; KATAYAMA, H.; AKAO, T.; HIGUCHI, K.; MIZUKI, E.; OHBA, M.; KANAI, R.; HARATA, K. Crystal structure of the Parasporin-2 Bacillus thuringiensis toxin that recognizes cancer cells. J. Mol. Biol. 121-133, 2009.

AKIBA, T.; ABE, Y.; KITADA, S.; KUSAKA, Y.; ITO, A.; ICHIMATSU, T.; KATAYAMA, H.; AKAO, T.; HIGUCHI, K.; MIZUKI, E.; et al. Crystallization of parasporin - 2, a Bacillus thuringiensis crystal protein with selective cytocidal activity against human cells. Acta Crystallogr. Sect. D: Biol. Crystallogr. V. 60, p. 2355 - 2357, 2004.

AKIBA, T.; HUGUCHI, K.; MIZUKI, E.; EKINO, K.; SHIN, T.; OHBA, M.; KANAI, R.; HARATA, K. Nontoxic crystal protein from Bacillus thuringiensis demonstrates a remarkable structural similarity to pore - forming toxins. Proteins: Struct. Funct. Bioinf. V. 63, p. 243 - 248, 2006.

AMERICAN CANCER SOCIETY. Cancer Facts \& Figures 2014. Atlanta, Ga: American Cancer Society, 2014.

AOKI, K.; CHEGÃSAKI, Y. Ãoeber die pathogenitãt dersog. sotto Bacillen (Ishiwata) bei seidenrauven. Mitt Med Fak Kais 13:419, 1915.

ARANTES, O.M.N.; VILAS-BÔAS, L.A.; VILAS-BÔAS, G.F.L.T. Bacillus thuringiensis: estratégias no controle biológico. In: SERAFINE, L.A.; BARROS, N. 2007.

ARDISSON-ARAÚJO, D.M.; MORGADO FDA, S.; SCHWARTZ, E.F.; CORZO, G.; RIBEIRO, B.M. A new theraphosid spider toxin causes early insect cell death by necrosis when expressed in vitro during recombinant baculoviruses infection. Jounal Plos one, 2013.

BECKER, N. Bacterial control of vector mosquitoes and black flies. In: Entomopathogenic Bacteria: From Laboratory to Field Application. Charles JF, Delecluse A and Nielsen-LeRoux (eds.). Dordrecht, Kluwer Academic Publishers, pp. 383-398, 2000.

BEN-DOV, E. Bacillus thuringiensis subsp. israelensis and Its Dipteran-Specific Toxins. Toxins, 6, 1222-1243, 2014.

BERLINER, E. Ãoeber die schlafsucht der mehlmottenraupe. Z Gesamte Getreidewes; 3:63, 1911.

BERRY, C. The bacterium, Lysinibacillus sphaericus, as an insect pathogen. $J$. Invertebr. Pathol. 109, 1-10, 2012.

BLISSARD, G.W. Baculovirus-insect cell interactions. Cytotechnology v. 20, p. 73-93, 1996. 
BLISSARD, G.W.; ROHRMANN, G.F. Baculovírus diversity and molecular biology. Annual Review of Entomology, v. 35, p. 127-55, 1990.

BRASIL. Instituto Nacional de Câncer. Estimativa 2016/2017: incidência de câncer no Brasil. Rio de Janeiro: INCA, 2016.

BRASSEUR, K.; AUGER, P.; ASSELIN, E.; PARENT, S.; CÔTÉ, J-C.; SIROIS, M. Parasporin - 2 from a new Bacillus thuringiensis 4R2 Strain Induces caspases Activation and Apoptosis in Human Cancer cel, 2015.

BRASSEUR, K.; AUGER, P.; ASSELIN, E.; PARENT, S.; CÔTÉ, J.C.; SIROIS, M. Parasporin-2 from a New Bacillus thuringiensis 4R2 Strain Induces Caspases Activation and Apoptosis in Human Cancer Cells. Journal Plos one, 2015.

BRAUNAGEL, S.C., RUSSELL, W.K., ROSAS-ACOSTA, G., RUSSELL, D.H., and SUMMERS, M.D. Determination of protein composition of the occlusion-derived virus of Autographa californica nucleopolyhedrovirus. Proc. Natl. Acad. Sci. USA 100:97979802, 2003.

BRAVO, A.; GILL, S.S.; SOBERÓN, M. Comprehensive Molecular Insect Science. Elsevier BV. Bacillus thuringiensis Mechanisms and Use; p. 175-206, 2005.

BRAVO, A.; GILL, S.S.; SOBERÓN, M. Mode of action of Bacillus thuringiensis Cry and Cyt toxins and their potential for insect control. Toxicon Rev. v. 49(4), p423-35, 2007.

BRAVO, A.; GILL, S.S.; SOBERÓN, M. Mode of action of Bacillus thuringiensis Cry and Cyt toxins and their potential for insect control. Toxicon, 49, 423-435, 2007.

BRAVO, A.; HENDRICKX, K.; JANSEMS, S.; PEFEROEN, M. Immunocytochemical analyses of specific binding od Bacillus thuringiensis insecticidal crysral proteins to Lepidopteran and Coleopteran midgut membranes. J. Ivertebr. Pathol. 60, 247-253, 1992.

BRAVO, A.; LIKITVIVATANAVONG, S.; GILL, S.S.; SOBERÓN, M. Bacillus thuringiensis: A story of a successful bioinsecticide. Insect Biochem. Mol. Biol., 41, 423-431, 2011.

BRAVO, A.; SOBERÓN, M. How to cope with insect resistance to Bt toxins? Trends Biotechnol. 26, 573-579, 2008.

BUTKO, P. Citolytic toxin Cyt1A and its mechanism of membrane damage: data and hypotheses. Appl. Environ. Microbiol. V.69, p.2415-2422, 2003.

CASTRO, M.E.B.; SOUZA, M.L.: SIHLER, W.; RODRIGUES, J.L.C.M.; RIBEIRO, B.M. Biologia Molecular de baculovírus e seu uso no controle biológico de pragas no Brasil. Pesquisa Agropecuária Brasileira v.34, p.1733-1761, 1999.

CHOUGULE, N.P.; BONNING, B.C. Toxins for transgenic resistance to hemipteran pests. Toxins, 4, 405-429, 2012.

COHEN, S.; ALBECK, S.; BEN-DOV, E.; CHAN, R.; FIRER, M.; ZARITSKY, A.; DYN, O. Cyt1Aa toxin: Crystal structure reveals implications for its membraneperforating function. J. Mol. Biol 413, 804-814, 2011. 
COHEN, S.; DYM, O.; ALBECK, S.; BEN-DOV, E.; CAHAN, R.; FIRER, M.; ZARITSKY, A. High-resolution crystal structure of activated Cyt2Ba monomer from Bacillus thuringiensis subsp. Israelensis. J. Mol. Biol. V.380, p.820-827, 2008.

COLE, A.R.; GILBERT, M.; POPOFF, M.; MOSS, D.S.; TITBALL, R.W.; BASAK, A.K. Clostridium perfringens epsilon-toxin shows structural similarity to the poreforming toxin aerolysin. Nat. Struct. Mol. Biol. 11, 797-798, 2004.

CORREA, R.F.T. ; AGUIAR, R. W. DE S.; MONNERAT, R. G.; RIBEIRO, B. M. CRY4AA and CRY4BA from Bacillus Thuringiensis SUBSP. Israelensis expressed in insect cells by recombinant Baculoviruses are Toxic to Aedes Aegypt Larvae. Virus Reviews and Research, v. 18, p. 1-10, 2013.

CRICKMORE, N.; ZEIGLER, D.R.; FEITELSON, J.; SCHNEPF, E.; VAN RIE, J.; LERECLUS, D.; BAUM, J.; DEAN, D.H. Revision of the nomenclature for the Bacillus thuringiensis pesticidal crystal proteins; Microbiol Mol Biol Rev.P.807 813, 1998. http://www.biols.susx.ac.uk/Home/Neil_Crickmore/Bt/index.html 1998.

CRICKMORE, N.; ZEIGLER, D.R.; SCHNEPF, E.; VAN RIE, J.; LERECLUS, D.; BAUM, J.; BRAVO, A.; DEAN, D.H. Bacillus thuringiensis Toxin Nomenclature. Available online: http://www.lifesci. sussex.ac.uk/Home/Neil_Crickmore/Bt/ (acessado em 10 de Abril de 2016).

CZAJKOWSKY, D.M.; HOTZE, E.M.; SHAO, Z.; R.K. Tweten, Vertical collapse of a cytolysin prepore moves its transmembrane beta-hairpins to the membrane, EMBO J. 23 3206-3215, 2004.

DE MAAGD, R.A.; BRAVO, A.; BERRY, C.; CRICKMORE, N; SCHNEPF, H.E. Structure, diversity, and evolution of protein toxins from spore-forming entomopathogenic bacteria. Annu. Rev. Genet. 37, 409-433, 2003.

DE MAAGD, R.A.; BRAVO, A.; BERRY, C.; CRICKMORE, N. How Bacillus thuringiensis has evolved specific to colonize the insect world. Trends Genet., v.17, p.193-199, 2001.

De MAAGD, R.A.; BRAVO, A.; CRICKMORE, N. How Bacillus thuringiensis has evolved specific toxins to colonize the insect world. Trends Genet. 17, 193-199, 2001.

DIDELOT, X.; BARKER, M.; FALUSH, D.; PRIEST, F.G. Evolution of pathogenicity in the Bacillus cereus group. Syst. Appl. Microbiol. 32, 81-90, 2009.

FEIL, S.C.; POLEKHINA, G.; GORMAN, M.A.; PARKER, M.W. Proteins membrane binding and pore formation introduction. Adv. Exp. Med. Biol. 677, 1-13, 2010.

GENY, B. and POPOFF, M.R. Bacterial protein toxins and lipids: pore formation or toxin entry into cells. Biol. Cell. 98, 667-678, 2006.

GENY, B.; POPOFF, M.R. Bacterial protein toxins and lipids: Pore formation or toxin entry into cells. Biol. Cell. 98, 667-678, 2006. 
GLARE, T.R.; O'CALLAGHAN, M. Bacillus thuringiensis: biology, ecology and safety. Chichester: John Wiley, 350 p, 2000.

GÓMEZ，I.; ARENAS, I.; BENITEZ，I.; MIRANDA-RIOS，J.; BECERRIL，B.; GRANDE, R.; ALMARGO, J.C.; BRAVO, A.; SOBERÓN, M. Specific epitopes of domains II and III of Bacillus thuringiensis Cry1 Ab toxin involved in the sequential interaction with cadherin and aminopeptidase-N receptors in Manduca sexta. J. Biol. Chem. 281, 34032-34039, 2006.

GÓMEZ, I.; SANCHEZ, J.; MIRANDA, R.; BRAVO, A.; SOBERÓN, M. Cadherinlike receptor binding facilitates proteolytic cleavage of helix $\alpha 1$ in domain I and oligomer pre-pore formation of Bacillus thuringiensis Cry1 Ab toxin. FEBS Lett. 513, 242-246, 2002.

GONZALES, M.R.; BISCHOFBERGER, M.; PERNOT, L.; VAN DER GOOT, F.G.; FRECHE, B. Bacterial pore-forming toxins: The (w)hole story? Cell Mol. Life. Sci. 65, 493-507, 2008.

GRANADOS, R.R.; LI, G.X.; DERKSEN, A.C.G.; McKENNA, K.A. A new insect cell line from Trichoplusia ni (BTI-Tn-5B1-4) susceptible to Trichoplusia ni single enveloped nuclear polyhedrosis virus. Journal of Invertebrate Pathology. v. 64, p. 260266, 1994.

GRIFFITS, J.S.; HASLAM, S.M.; YANG, T.; GARCYNSKI, S.F.; MULLOY, B.; MORRIS, H.; CREMER, P.S.; DELL, A.; ADANG, M.J.; AROIAN, R.V. Glycolipids as receptors for Bacillus thuringiensis crystal toxin. Science, 307, pp. 922-925, 2005.

GUEX, N.; PEITSCH, M.C.; SCHWEDE, T. Automated comparative protein structure modeling with SWISS-MODEL and Swiss-PdbViewer: A historical perspective. Electrophoresis, 30, 162-173, 2009.

HABIB, M.EM,; ANDRADE, C.F.S. Bactérias entomopatogênicas. In controle microbiana de insetos. Editado por S.B. Alves. 2. Ed. FEALQ, Piracicaba, PP. 383-446, 1998.

HARBECK, N. Breast cancer: Increasing therapy options for HER2-positive early breast cancer. Nat Rev Clin Oncol, v.9, n. 1, p10-12, 2011.

HASTOWO, S.; LAY, B.W.; and OHBA, M. Naturally occuring Bacillus thuringiensis in Indonesia. Jounal of Applied Bacteriology 73, 108 - 113, 1992.

HITCHMAN, R.; POSSEE, R. D.; and KING, L. Baculovirus expression systems for recombinant, 2009.

HOFFMANN, C.; VANDERBRUGGEN, H.; HOFTE, J.; VAN RIE, J.; JANSENS, H.; MELLAERT, J. Specificity of Bacillus thuringiensis $\delta$ - endotoxin is correlated with the presence of high-affinity binding sites in the brush border membrane of target insect midguts. Proceeding of the National Academy of Sciences of the United States of America, v. 85, p. 7844 - 7848, 1988.

HÖFTE, H.; WHITELEY, H.R. Insecticidal Crystal Proteins of Bacillus thuringiensis. Microbiol. Rev. 53, 242-255, 1989. 
http://www.canalminassaude.com.br/noticia/oms-divulga-pesquisa-sobre-a incidenciade-cancer-no-mundo-e-faz-alerta-sobre-o-cancer-de-mama/ (Acessado dia 14/01/2013 as 21:00 horas).

ISHIWATA, S. On a kind of severe flacherie (sotto disease). Dainihon Sanshi Kaiho 114: 1-5, 1901.

ITO, A.; SASAGURI, Y.; KITADA, S.; KUSAKA, Y.; KUWANO, K.; MASUTOMI, K.; MIZUKI, E.; AKAO, T.; OHBA, M. A Bacillus thuringiensis crystal protein with selective cytocidal action to human cells. J Biol Chem 279: 21282-21286, 2004.

JEHLE, J.A.; BLISSARD, G.W.; BONNING, B.C.; CORY, J.S.; HERNIOU, E.A.; ROHRMANN, G.F.; THEILMANN, D.A.; THIEM, S.M.; VLAK, J.M. On the classification and nomenclature of baculoviruses: a proposal for revision. Arch. Virol. V. 151, p.1257-1266, 2006.

JUAREZ, J. N.; MUÑOZ, G. C.; GÓMEZ, I., GILL, S. S.; SOBRÓN, M.; BRAVO, A. The prepore from Bacillus thuringiensis Cry1Ab toxin is necessary to induce insect death in Manduca sexta. Peptides. V. 29, p. 318-323, 2008.

KATAYAMA, H.; KUSAKA, Y.; YOKOTA, H.; AKAO, T.; KOJIMA, M.; NAKAMURA, O.; MEKADA, E.; MIZUKI, E. Parasporin-1, a novel cytotoxic protein from Bacillus thuringiensis, induces $\mathrm{Ca} 2+$ influx and a sustained elevation of the cytoplasmic Ca2+ concentration in toxin-sensitive cells. J Biol Chem 282: 7742-7752, 2007.

KATAYAMA, H.; YOKOTA, H.; AKAO, T.; NAKAMURA, O.; OHBA, M.; MEKADA, E.; MIZUKI, E. Parasporin-1, a novel cytotoxic protein to human cells from non-insecticidal parasporal inclusions of Bacillus thuringiensis. J. Biochem. 137, 17-25, 2005.

KIM, H. S.; YAMASHITA, S.; AKAO, T.; SAITOH, H.; HIGUCHI, K.; PARK, Y. S.; MIZUKI, E.; OHBA, M. In vitro cytotoxicity of non-Cyt inclusion proteins of a Bacillus thuringiensis isolate against human cells, including cancer cells. J. Appl. Microbiol. V. 89 , p. $16-23,2000$.

KITADA, S.; ABE, Y.; MAEDA, T.; SHIMADA, H. Parasporin-2 requires GPIanchored proteins for the efficient cytocidal action to human hepatoma cells. Toxicology 264, 80-88, 2009.

KITADA, S.; ABE, Y.; SHIMADA, H.; KUSAKA, Y.; MATSUO, Y.; KATAYAMA, H.; OKUMURA, S.; AKAO, T.; MIZUKI, E.; KUGE, O.; SASAGURI, Y.; OHBA, M.; ITO, A. Cytocidal actions of parasporin-2, an anti-tumour crystal toxin from Bacillus thuringiensis. Journal of Biological Chemistry ; 281(36): 26350-60. 2006.

KNOWLES, B. Mechanism of action of Bacillus thuringiensis insecticidal $\delta$ endotoxins. Adv. Insect. Physiol. 24, 275-308, 1994.

KNOWLES, B.H.; DOW, J.A.T. The crystal delta-endotoxins of Bacillus 
thuringiensis - Models for their mechanism of action on the insect gut. Bioessays, 15, 469-476, 1993.

KONI, P.A.; ELLAR, D.J. Biochemical characterization of Bacillus thuringiensis cytolytic $\delta$ - endotoxins. Microbiology 140, 1869-1880, 1994.

KOST, T.A.; CONDREAY, J.P.; and JARVIS, D.L. Baculovirus as versatile vectors for protein expression in insect and mammalian cells. Nat. Biotechnol. 23:567-575, 2005.

LEE, D.W.; KATAYAMA, H.; AKAO, T.; MAEDA, M.; TANAKA, R.; YAMASHITA, S.; SAITOH, H.; MIZUKI, E.; OHBA, M. A $28 \mathrm{kDa}$ protein of the Bacillus thuringiensis serovar shandongiensis isolate 89-T-34-22 induces a human leukemic cell-specific cytotoxicity. Biochim. Biophys. Acta, 1547, 57-63, 2001.

LERECLUS, D.; BOURGOUIN, C.; LECADET. M.M.; KLIER, A.; RAPOPORT, G. Role, structure, and molecular organization of the genes coding for the parasporal $\mathrm{d}$ endotoxins of Bacillus thuringiensis. In: Regul. Prokaryotic develop., eds. Issae, Smith, R.; Slepecky, A.; Setlow, P.; Washington: American Society for Microbiology, p.71-88, 1989.

LERECLUS, D.; DELÉCLUSE, A.; LECADET, M-M. Diversity od Bacillus thuringiensis toxins and genes. In: Bacillus thuringiensis, An Environmental biopesticide: Theory and practice. Enwistle, P. F.; Cory, J. S.; Bailey M. J. and Higgs, S. Eds.; John Wioley \& Sons Ltd, West Sussex, England, p37-69, 1993.

LI, J.D.; CARROLL, J.; ELLAR, D.J. Crystal structure of insecticidal $\delta$-endotoxin from Bacillus thuringiensis at $2.5 \AA$ A resolution. Nature, 353, 815-821, 1991.

LIMA, G.M.S.; AGUIAR, R.W.DE S.; CORREA, R.F.T. ;MARTINS, É.S.; GOMES, A.C.M.M.; NAGATA, T.;; SOUZA, M.T.; MONNERAT, R.G.; RIBEIRO, Bergmann Morais. Cry2A toxins from Bacillus thuringiensis expressed in insect cells are toxic to two lepidopteran insects. World Journal of Microbiology and Biotechnology, v. 24, p. 2941-2948, 2008.

LIN, S. C.; LO, Y. C.; LIN, J. Y.; LIAW, Y. C. Crystal structures and electron micrographs of fungal volvatoxin A2. J. Mol. Biol. V. 343, p. 477 - 491, 2004.

LIU, Y.; DECAROLIS, N.; BEEK, N.VAN. Protein production with recombinant baculoviruses in lepidopteran larvae. Methods in molecular biology (Clifton, N.J.), v. 388, p. 267-80, jan. 2007.

LU, A.; MILLER, L.K. (1997). Regulation of baculovirus late and very late gene expression. The baculoviruses. Plenum Prest, New York, 1997.

MAÑES, S.; DEL REAL, G.; and MARTI NEZ, A.C. Pathogens: raft hijackers. Nat. Rev. Immunol. 3, 557-568, 2003.

MARTENS, J.W.; KNOESTER, M.; WEIJTS, F.; GROFFEN, S.J.; HU, Z.; BOSH, D.; VLAK, J.M. Characterization of baculovírus insecticides expressing tailored Bacillus thuringiensis CryIA (b) crystal proteins. J Invertebr Pathol 66:249-257, 1995. 
MARTINS, É. S.; AGUIAR, R. W. DE. S.; MARTINS, N. F.; MELATTI, V. M.; FALCÃO, R.; GOMES, A. S. M. M.; RIBEIRO, BERGMANN MORAIS.; MONNERAT, R. G. Recombinant CrylIa protein is highly toxic to cotton boll weevil (Anthonomus grandis Boheman) and fall armyworm (Spodoptera frugiperda).. Journal of Applied Microbiology, v. 104, p. 1363-1371, 2008.

MARTINS, É. S.; MONNERTA, R. G.; QUEIROZ, P. R.; DUMAS, V. F.; BRAZ, S.; DE SOUZA AGUIAR, R. W.; MENDES GOMES, A. C. M.; SÁNCHEZ, J.; BRAVO, A.; RIBEIRO, BERGMANN MORAIS. Midgut GPI- anchored proteins with alkaline phosphatase activity from the cotton boll weevil (Anthonomus grandis) can be the putative receptors for the Cry1B protein of Bacillus thuringiensis. Insect Biochemistry and Molecular Biology, v. 40, p. 138-145, 2010.

MARUNIAK, J. E. Baculovirus structural proteins and protein synthesis. In: Granados, R.R., Fredererici, B. A. (Eds). The Biology of Baculovirus. Boca Raton: CRC Press, p. $275,1986$.

MAUGHAN, K.L.; LUTTERBIE, M.A.; HAM, P.S. Treatment of breast cancer. Am Fam Physician, v.81, n. 11, p. 1339-1346, 2010.

MEADOWS, M.P.; ELLIS, D.J.; BUTT, J.; JARRETT, P.; And BURGES, H.D. Distribution, frequency, and diversity of Bacillus thuringiensis in an animal feed mil. Applied and Environmental Microbiology 80, 56-64,1992.

MELTON, J. A.; PARKER, M. W.; ROSSJOHN, J.; BUCKLEY, J. T.; TWETEN, R. K. The identification and structure of the membrane-spanning domain of the Clostridium septicum $\alpha$-toxin. J. Biol. Chem. V. 279, p. 14315 - 14322, 2004.

MERRYWEATHER, A.T.; WEYER, U.; HARRIS, M.P.G.; HIRST, M.; BOOTH, T.; POSSEE, D. Cobstruction of genetically engineered baculovírus insecticides containing the Bacillus thuringiensis subsp. Kurstaki HD-73 delta-endotoxin. J Gen Virol 71:15351544, 1990.

MILLER, L.K. Introduction to the baculoviruses. In: MILLER, L.K. The baculoviruses. Plenum Press, New York. p.1-6. 1997.

MILLER, L.K.; and DAWES, K.P. Restriction endonuclease analysis for the identification of baculovirus pesticides. Appl. Environ. Microbiol. 35: 411-421, 1978.

MIZUKI, E.; OHBA, M.; AKAO, T.; YAMASHITA, S.; SAITOH, H.; PARK, YS. Unique activity associated with non-insecticidal Bacillus thuringiensis parasporal inclusions: in vitro cell-killing action on human cancer cells. Journal of Applied Microbiology .86:477-86, 1999.

MIZUKI, E.; PARK, YS.; SAITOH, H.; YAMASHITA, S.; AKAO, T.; HIGUCHI, K.; OHBA, M. Parasporin, a human leukaemic cell-recognizing parasporal protein of Bacillus thuringiensis. Clinical and Diagnostic Laboratory Immunology . 7:625-34, 2000. 
MONNERAT, R. G.; BRAVO, A. Proteínas bioinseticidas produzidas pela bacteria Bacillus thuringiensis: modo de ação e resistncia. Controle Biológico. 3, 163, 2000.

O'REILLY, D.R.; MILLER, L.K. \& LUCKOW, V. Baculovirus expresión vectors: a laboratory manual. W. H. Fressman and Company, New York, 1992.

OHBA, M. hba M Bacillus thuringiensis diversity in soil and phylloplane. In: Logan NA, De Vos P (eds) Endospore-forming soil bacteria, soil biology, vol 27. Springer, Berlin, pp 215-233, 2011.

OHBA, M.; CRICKMORE, N.; CÔTÉ, J.C.; NAGAMATSU, Y.; KITADA, S.; SAKAI, H.; HARATA, K.; SHIN, T. Parasporin nomenclature. Disponível em: <http://parasporin.fitc.pref.fukuoka.jp/>. Acesso em: 20 de junho de 2016.

OHBA, M.; MIZUKI, E.; UEMORI, A. Parasporin, a new anticancer protein group from Bacillus thuringiensis. Anticancer Res. 29, 427-433, 2008.

OKUMURA, S.; AKAO, T.; HIGUCHI, K.; SAITOH, H.; MIZUKI, E.; OHBA, M.; INOUYE, K. Bacillus thuringiensis serovar shandongiensis strain 89-T-34-22 produces multiple cytotoxic proteins with similar molecular masses against human cancer cells. Lett. Appl. Microbiol. 39, 89-92, 2004.

OKUMURA, S.; OHBA, M.; MIZUKI, E.; CRICKMORE, N.; COTÉ, J.-C.; NAGAMATSU, Y.; KITADA, S.; SAKAI, H.; HARATA, K.; SHIN, T.; et al. Parasporin Nomenclature. Available online: http://parasporin.fitc.pref.fukuoka.jp/ (acessado em 10 de Abril de 2016).

OKUMURA, S.; SAITOH, H.; ISHIKAWA, T.; INOUYE, K.; MIZUKI, E. Mode of action of parasporin-4, a cytocidal protein from Bacillus thuringiensis. Biochim. Biophys. Acta. 1808, 1476-1482, 2011.

OKUMURA, S.; SAITOH, H.; ISHIKAWA, T.; MIZUKI, E.; INOUYE, K. Identification and characterization of a novel cytotoxic protein, parasporin-4, produced by Bacillus thuringiensis A1470 strain. Biotechnol. Annu. Rev. 14, 225-252, 2008.

PALMA, LEOPOLDO.; MUÑOZ, DELIA.; BERRY, COLIN.; MURILLO, JESÚS.; CABALLERO, PRIMITIVO. Bacillus thuringiensis Toxins: An Overview of their Viocidal Activity. Toxins. V.6, p 3296-3325, 2014.

PALMER, M.; HARRIS, R.; FREYTAG, C.; KEHOE, M.; TRANUM-JENSEN, J.; BHAKDI, S. Assembly mechanism of the oligomeric streptolysin O pore: the early membrane lesion is lined by a free edge of the lipid membrane and is extended gradually during oligomerization. EMBO J. 17, 1598-1605, 1998.

PAYNE, C.M.; BOMBLE, Y.J.; TAYLOR, C.B.; McCABE, C.; HIMMEL, M.E.; CROWLEY, M.F.; BECKHAM, G.T. Multiple functions of aromatic-carbohydrate interactions in a processive cellulase examined with molecular simulation. J. Biol. Chem. 286, 41028-42035, 2011.

PEGRAM, M.; LIAO, J. Trastuzumab treatment in multiple lines: currenr data ans future directions. Clin Breast Cancer, v. 12, n. 1, p. 10-18, 2012. 
PUHALlA, S.; BHATTACHARYA, S.; DAVIDSON, N. E. Hormonal therapy in breast cancer: Amodel disease for the personalization of cancer care. Mol Oncol, v.6, $\mathrm{n}$. 2, p. 222-236, 2012.

PURUSHOTHAM, A. D.; LEWISON, G.; SULLIVAN, T. The state of research and development in global cancer surgery. Ann Surg. V. 255, p. 427 - 432, 2012.

RAHBANI, J.M.; SALAMEH, D.; AWAD, M.K.; CHAMY, L.; BRANDAM, C.; LTEIF, R. A simple method for the separation of Bacillus thuringiensis spores and crystals. Journal of Microbiological Methods. V. 107, p. 147-149, 2014.

RAYMOND, B.; JOHNSTON, P.R.; NIELSEN-LEROUX, C.; LERECLUS, D.; CRICHMOR, N. Bacillus thuringiensis: An impotent pathogen? Trends Microbiol. 18, 189-194, 2010.

RIBEIRO, B.M.; CROOK, N.E. Construction of occluded recombinant baculovíruses containing the full-length cry1Ab and cry1Ac genes from Bacillus thuringiensis. Braz $J$ Med Biol Res 31:763-769,1998.

RIBEIRO, B.M.; CROOK, N.E. Expression of full length and truncated forms of crystal proteins genes form Bacillus thuringiensis subsp. Kurstaki in baculovirus an pathogenicity of the recombinant viruses. J Invertebr Pathol 62:121-130, 1993.

ROCHULSKI, P.; MASSON, L.; BORISOVA, S.; PUSZTAICAREY, M.; SCHWARTZ, J.L.; BROSSEAU, R.; CYGLER, M. Bacillus thuringiensis CrylA(a) insecticidal toxin: Crystal structure and channel formation. J. Mol. Biol. 254, 447-464, 1995.

ROH, J.Y.; CHOI, J.Y.; LI, M.S.; JIN, B.R.; JE, Y.H. Bacillus thuringiensis as a specific, safe, and effective tool for insect pest control. J. Mol. Biol. 17, 547-559, 2007.

ROH, J.Y.; PARK, H.W.; JIN, B.R.; KIM, H.S.; YU, Y.M; and KANG. S.K. Characterization of novel non-toxic Bacillus thuringiensis isolated from Korea. Letters in Applied Microbiology 23, 249-252, 1996.

ROHRMANN, G. F. Polyhedrin Structure. Journal of general virology 67, 1499-1513, 1986.

ROSSJOHN, J.; FEIL, S. C.; MCKINTRY, W. J.; TSERNOGLOU, D.; VAN DER GOOT, G.; BUCKLEY, J.T.; PARKER, M. W. Aerolysin-a paradigm for membrane insertion of beta-sheet protein toxins? J. Struct. Biol. V. 121, P. 92 - 100, 1998.

SAITOH, H.; OKUMURA, S.; ISHIKAWA, T.; AKAO, T.; MIZUKU, E.; OHBA, M. Investigation of a novel Bacillus thuringiensis gene encoding a parasporal protein, parasporin-4, that preferentially kills human leukemic $\mathrm{T}$ cells. Biosci Biotechnol Biochem 70: 2935- 2941, 2006. 
SAMBROOK, J.; RUSSEL, D.W. Molecular Cloning: A Laboratory Manual. Third Edition (Plainview, New York: Cold Spring Harbor Laboratory Press), 2001.

SCHWARTZ, R.; ISTRAIL, S.; KING, J. Frequencies of amino acid strings in globular protein sequences indicate suppression of blocks consecutive hydrophobic residues. Protein Sci. V. 10, p. 1023-1031, 2001.

SCHWEDE, T.; KOPP, J.; GUEX, N.; PEITSCH, M.C. SWISS-MODEL: an automated protein homology-modeling server. Nicleic Acids Research Vol. 31. No. 13 3381-3385, 2003.

SOBERÓN, M.; GILL, S.S.; BRAVO, A. Signaling versus punching hole: How do Bacillus thuringiensis toxins kill insect midgut cells? Cell. Mol. Life Sci. 66, 13371349, 2009.

SZEWCZYK, B.; RABALSKI, L.; KROL, E.; SIHLER, W.; and SOUZA, M. L. Baculovirus biopesticides - a safe alternative to chemical protection of plants. J. Biopestic. 2:209-216, 2009.

TANI, H.; LIMN, K.C.; YAP, C.C.; ONISHI, M.; NOZAKI, M.; NISHIMUNE, Y.; OKAHASHI, N.; KITAGAWA, Y.; WATANABE, R.; MOCHIUZUKI, R.; MORIISHI, K.; MATSUURA, Y. In Vitro and in Vivo Gene Delivery by Recombinant Baculoviruses. J. Virol. 77(18):9799, 2003. DOI: 10.1128/JVI.77.18.9799-9808, 2003.

TILLEY, S.J. and SAIBIL, H.R. The mechanism of pore formation by bacterial toxins. Curr. Opin. Struct. Biol. 16, 230-236, 2006.

TILLEY, S.J.; ORLOVA, E.V.; GILBERT, R.J.; ANDREW, P.W.; SAIBIL, H.R. Structural basis of pore formation by the bacterial toxin pneumolysin, Cell $121247-$ 256, 2005.

VAN FRANKENHUYZEN, K. Insecticidal activity of Bacillus thuringiensis crystal proteins. J. Invertebr. Pathol. 101, 1-16, 2009.

VAUGHN, J. L.; GOOWIN, R. H.; TOMPKINS, G. J.; MCCAWLEY, P. The establishment of two cell lines from insect Spodoptera frugiperda (Lepidoptera: Noctuidae). In vitro. V. 13, p213 - 217, 1977.

WARREN, G.W.; KOZIEL, M.G.; MULLINS, M.A.; NYE, G.J.; CARR, B.; DESAI, N.M.; KOSTICHKA, K.; DUCK, N.B.; ESTRUCH, J.J. Auxiliary Proteins for Enhancing the Insecticidal Activity of Pesticidal Proteins. U.S. Patent 5,770,696, 23 June 1998.

WU, P. T.; LIN, S. C.; HSU, C. I.; LIAW, Y. C.; LIN, J. Y. Inhibitory effects of nontoxic protein amphipathic alpha-helix. Febs j. V. 273, p. $3160-3171$.

XU, CHENGCHEN.; WANG, BI-CHENG.; YU, ZINIU.; SUN, MING. Structural Insights into Bacillus thuringiensis Cry, Cyt and Parasporin Toxins. Toxins. V.6, p. 27322770, 2014. 
YAMASHITA, S.; AKAO, T.; MIZUKI, E.; SAITOH, H.; HIGUCHI, K.; PARK, YS.; KIM, H-S.; OHBA, M. Characterization of the anti-cancer-cell parasporal proteins of a Bacillus thurinhiensis isolate. Can J Microbiol 46:913-919, 2000.

YAMASHITA, S.; KATAYAMA, H.; SAITOH, H.; AKAO, T.; PARK, Y.S.; MIZUKI, E.; OHBA, M.; ITO, A. Typical three-domain Cry proteins of Bacillus thuringiensis strain A1462 exhibit cytocidal activity on limited human cancer cells. $J$. Biochem. 138, 663-672, 2005.

ZHANG, X.; CANDAS, M.; GRIKO, N.B.; ROSE-YOUNG, L.; BULLA, L.A. Cytotoxicity of Bacillus thuringiensis Cry1 Ab toxin depends on specific binding of the toxin to the cadherin receptor BT-R ${ }_{1}$ expressed in insect cells. Cell. Death. Differ. 12, 1407-1416, 2005.

ZHANG, X.; CANDAS, M.; GRIKO, N.B.; TAUSSING, R.; BULLA, L.A.JR. A mechanism of cell death involving an adenylyl cyclase/PKA signaling pathway is induced by the Cry1 Ab toxin of Bacillus thuringiensis. Proc. Natl. Acad. Sci. v.103, p.9897-9902, 2006.

ZHUANG, M.; OLTEAN, D.1.; D.I.; GOMEZ, PULLIKUTH, A.;K.; SOBERON, M.; BRAVO, A. Heliothis virescens and Manduca sexta lipid rafts are involved in Cry1A toxin binding to the midgut epithelium and subsequent pore formation. J. Biol. Chem. V.277, p.13863-13872, 2002. 